UNIVERSIDADE DE BRASÍLIA

FACULDADE DE AGRONOMIA E MEDICINA VETERINÁRIA

PROGRAMA DE PÓS-GRADUAÇÃO EM AGRONOMIA

\title{
PARÂMETROS GENÉTICOS E OBTENÇÃO DE GENÓTIPOS DE SOJA COM AUSÊNCIA DE LIPOXIGENASE E CARACTERÍSTICAS AGRONÔMICAS EM BAIXAS LATITUDES
}

ELONHA RODRIGUES DOS SANTOS

TESE DE DOUTORADO EM AGRONOMIA

Área de concentração: Produção Sustentável

Linha de pesquisa: Recursos Genéticos e Melhoramento Vegetal

BRASÍLIA/DF

MARÇO DE 2016 
UNIVERSIDADE DE BRASÍLIA

FACULDADE DE AGRONOMIA E MEDICINA VETERINÁRIA

PROGRAMA DE PÓS-GRADUAÇÃO EM AGRONOMIA

\section{PARÂMETROS GENÉTICOS E OBTENÇÃO DE GENÓTIPOS DE SOJA COM AUSÊNCIA DE LIPOXIGENASE E CARACTERÍSTICAS AGRONÔMICAS EM BAIXAS LATITUDES}

ELONHA RODRIGUES DOS SANTOS

ORIENTADOR: CARLOS ROBERTO SPEHAR

TESE DE DOUTORADO EM AGRONOMIA

PUBLICAÇÃO: 041D/2016

BRASÍLIA/DF

MARÇO DE 2016 


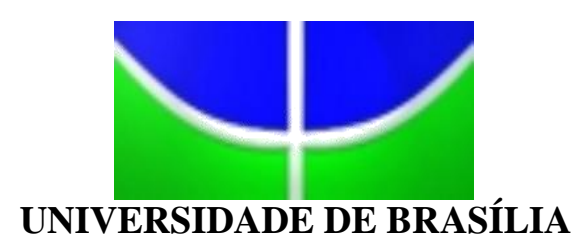

FACULDADE DE AGRONOMIA E MEDICINA VETERINÁRIA

PROGRAMA DE PÓS-GRADUAÇÃO EM AGRONOMIA

\title{
PARÂMETROS GENÉTICOS E OBTENÇÃO DE GENÓTIPOS DE SOJA COM AUSÊNCIA DE LIPOXIGENASE E CARACTERÍSTICAS AGRONÔMICAS EM BAIXAS LATITUDES
}

\author{
ELONHA RODRIGUES DOS SANTOS
}

TESE DE DOUTORADO SUBMETIDA AO PROGRAMA DE PÓSGRADUAÇÃO EM AGRONOMIA, COMO PARTE DOS REQUISITOS NECESSÁRIOS À OBTENÇÃO DO GRAU DE DOUTOR EM AGRONOMIA.

APROVADA POR:

CARLOS ROBERTO SPEHAR, PhD/ Universidade de Brasília - FAV/ PRESIDENTE/ CPF: 122.262.116-91/ e-mail: spehar@unb.br

NARA OLIVEIRA SILVA SOUZA, DOUTORA/ Universidade de Brasília - FAV/ MEMBRO INTERNO/ CPF: 033.300.726-36/ e-mail: narasouza@unb.br

MICHELLE SOUZA VILELA, DOUTORA/ Universidade de Brasília - FAV/ MEMBRO INTERNO/ CPF: 919.623.401-63/ e-mail: michellevilelaunb@gmail.com

TAISLENE BUTARELLO DE MORAES, DOUTORA/ Universidade de Brasília - FAV/ MEMBRO EXTERNO/ CPF: 269.394.408-28/ e-mail: taislene@unb.br

FÁBIO GELAPE FALEIRO, PhD/ Pesquisador da Embrapa Cerrados/ MEMBRO EXTERNO/ CPF: 739.634.706-82/ e-mail: fabio.faleiro@embrapa.br

Brasília/DF, 09 de março de 2016 


\title{
FICHA CATALOGRÁFICA
}

\author{
Santos, Elonha Rodrigues \\ Parâmetros genéticos e obtenção de genótipos de soja com ausência de lipoxigenase e \\ características agronômicas em baixas latitudes/ Elonha Rodrigues dos Santos. Orientação: Carlos \\ Roberto Spehar - Brasília, DF, 2016. \\ 160 p.: il. \\ Tese de Doutorado (Dr.) - Universidade de Brasília/ Faculdade de Agronomia e Medicina \\ Veterinária, 2016. \\ 1. Parâmetros genéticos. 2. Genótipos de soja. 3. Lipoxigenase. 4. Cerrado. 5. Cruzamentos. 6. \\ Soja alimento. I. Spehar, Carlos Roberto. II. Universidade de Brasília. Faculdade de Agronomia e \\ Medicina Veterinária. III. Doutor.
}

$\mathrm{CDD}$ ou $\mathrm{CDU}$

\section{REFERÊNCIA BIBLIOGRÁFICA}

SANTOS, E. R. Parâmetros genéticos e obtenção de genótipos de soja com ausência de lipoxigenase e características agronômicas em baixas latitudes. Brasília: Faculdade de Agronomia e Medicina Veterinária, Universidade de Brasília, 2016, 160 p. Tese de Doutorado.

\section{CESSÃO DE DIREITOS}

NOME DO AUTOR: Elonha Rodrigues dos Santos

TÍTULO DA TESE: Parâmetros genéticos e obtenção de genótipos de soja com ausência de lipoxigenase e características agronômicas em baixas latitudes.

GRAU: DOUTOR.

ANO: 2016.

É concedida à Universidade de Brasília permissão para reproduzir cópias desta tese de doutorado para única e exclusivamente propósitos acadêmicos e científicos. $\mathrm{O}$ autor reserva para si os outros direitos autorais de publicação. Nenhuma parte desta tese de doutorado pode ser reproduzida sem a autorização por escrito do autor. Citações são estimuladas, desde que citada à fonte.

Elonha Rodrigues dos Santos

CPF: 84197463120

Rua Olímpio Ferreira, n: 430 - Patos de Minas, MG e-mail: elonharodrigues@gmail.com 
Aos mens fithos amados Caio César e Daví Angusto Por tudo que representam em minha vida.

Ao meu companheiro César pelo amor e carinho.

A meus pais Antônio (ín memoriam) e Belchiolina pelo amor, ensinamento e exemplo.

Dedico 
Para ser o que sou hoje fui várias mulheres.

E se volto a me encontrar com as mulheres que fui, não me envergonho delas. Foram etapas do que sou. Tudo o que sei custou às dores das experiências.

Tenho respeito pelos que procuram, pelos que tateiam, pelos que erram. E o que é mais importante, estou persuadida que minha luz se extinguiria se eu fosse a única a possui-la." [Adaptado de Goethe] v 


\section{AGRADECIMENTOS}

A Deus agradeço pela vida e saúde, por ter me conduzido e sustentado durante todo esse período de estudo. Agradeço por ter me guiado e dado forças para chegar até o fim.

A minha mãe Belchiolina que mesmo distante sempre se manteve presente com seus sábios conselhos, incentivos e orações. As minhas irmãs pelo incentivo e apoio, em especial a Maria das Dores e Terezinha. A meu sobrinho Paulo Roberto Pereira por toda ajuda prestada.

Ao Professor Carlos Roberto Spehar agradeço imensamente pela orientação, atenção, profissionalismo e ensinamentos transmitidos. Agradeço ainda, por toda ajuda durante a condução desse projeto. Pela paciência, compreensão, amizade e pela credibilidade. Exemplo de pessoa e profissional. Meus imensuráveis agradecimentos.

A aluna de agronomia e estagiária Mariana Bohme agradeço pela imensa ajuda prestada na realização das análises em laboratório.

Aos professores: Everaldo Pereira agradeço pela área cedida para o experimento na Estação Biológica. Ao Professor Marcelo Fagioli agradeço pela ajuda prestada na condução do experimento na FAL. Ao Professor Luiz Antônio Borgo agradeço por disponibilizar o laboratório de alimentos.

À Coordenação de Aperfeiçoamento de Pessoal de Nível Superior, Capes/ Reuni, agradeço pela concessão de bolsa de estudos.

À banca examinadora pela disponibilidade, leitura criteriosa, sugestões e apontamentos indicados na redação desta tese.

Aos funcionários da UnB agradeço por toda ajuda prestada, em especial ao engenheiro agrônomo Luciano e ao laboratorista Márcio.

Aos Professores e palestrantes que ministraram aulas durante o curso, agradeço pelo conhecimento transmitido.

À Universidade de Brasília pela oportunidade de realizar o curso, pelas instalações e serviços prestados nas conduções das pesquisas.

Aos colegas da pós-graduação agradeço pelo convívio agradável durante o curso em especial a Angélica, Elisiane, Paula Andréa, Ana Catarina e Kleiton Aquiles.

Agradeço a Pesquisadora Mercedes Carrão-Panizzi, pela ajuda prestada.

Agradeço a Professora Michelle Vilela, pela ajuda na análise estatística.

A todos que generosamente contribuíram para a realização deste trabalho... 


\section{RESUMO}

A soja (Glycine max. (L.) Merrill) é uma importante alternativa alimentar na nutrição humana, apresenta alto teor e qualidade proteica, lipídios e vitaminas, além de ser considerada um alimento funcional. Entretanto, esse alimento é pouco usado pelos brasileiros devido ao sabor desagradável "beany flavor" atribuído pelas enzimas lipoxigenases. As lipoxigenases são dioxigenases que catalisam o oxigênio molecular aos ácidos graxos polinsaturados, formando compostos voláteis de cadeias curtas como aldeídos e cetonas, responsáveis pelos sabores indesejáveis. A inativação genética das lipoxigenases é considerada a alternativa mais eficiente de reduzir o sabor indesejável. Assim, a obtenção de cultivares de soja desprovidas dessas enzimas é um método interessante por manter as propriedades funcionais, contribuindo para otimização do sabor e aumentando sua aceitabilidade. Este trabalho teve como objetivo, obter genótipos de soja, com ausência das enzimas de lipoxigenases e que apresentem período juvenil longo com potencial para serem empregados no cultivo comercial, em regiões de baixa latitude no Cerrado Brasileiro. A etapa que analisou a introdução, crescimento e desenvolvimento da soja em baixa latitude foi realizada em Gurupi, TO. O desenho experimental foi de blocos ao acaso com quatro tratamentos e quatro repetições. Os tratamentos foram BRSMG 790A e BRS 257, cultivares de soja do tipo alimento: destinadas a alimentação; A7002 e M 8585, do tipo comum de grão, destinadas a produção de óleo e farelo. Avaliaram-se o crescimento e os componentes agronômicos. A análise de crescimento foi eficaz em avaliar a resposta biológica da soja do tipo de alimento, quando introduzida em baixas latitudes. As etapas seguintes que incluíram as hibridações, avanço das gerações $F_{1}$ e $F_{2}$ foram conduzidas em Brasília, DF. Os cruzamentos foram realizados em casa de vegetação usando genitores com período juvenil longo e genitores com ausência das enzimas lipoxigenases (destinadas ao consumo na alimentação humana). A geração $F_{1}$ foi cultivada em canteiros na Estação de Biologia da UnB. Para realizar as avaliações agronômicas e determinação dos parâmetros genéticos foi instalado um experimento, na Fazenda Água Limpa (FAL), para avaliar as plantas da geração $F_{2}$. Para determinar a presença e ausência das lipoxigenases foram realizadas analises, em laboratório, usando o método colorimétrico, nas progênies $F_{2}$ com altura igual e superior a $70 \mathrm{~cm}$. A análise dos componentes genéticos demostraram elevada probabilidade de ganhos por seleção evidenciada pelos elevados valores de herdabilidade, $\mathrm{CVg} / \mathrm{CVe}$ nas populações $\mathrm{F}_{2}$, com seleção favorável para número de dias à maturação, altura de plantas, número de vagens por planta e rendimento. Entretanto, a influência ambiental elevada dificulta a seleção por altura de inserção de vagem. As correlações demostraram que é possível realizar seleções indiretas daqueles caracteres com menor herdabilidade para obter genótipos desejáveis. As hibridações entre cultivares de soja com período juvenil longo e cultivares com ausência de lipoxigenase, originaram na geração $F_{2}, 35$ progênies de soja com período juvenil longo, com altura superior a $70 \mathrm{~cm}$ e ausência de lipoxigenases, com potencial de serem avançadas e lançadas como cultivar para a região do Cerrado.

Palavras-chave: Glycine max., soja alimento, melhor sabor, progênies $\mathrm{F}_{2}$, componentes genéticos, lipoxigenases. 


\begin{abstract}
Soybean (Glycine max. (L.) Merrill) is an important alternative food in human nutrition, has high content and quality protein, lipids and vitamins, and is considered a functional food. However, this food is rarely used by Brazilians due to the unpleasant taste "beany flavor" provided by lipoxygenase. The lipoxygenases are dioxygenase catalyzing the molecular oxygen to polyunsaturated fatty acids, forming volatile compounds such as short chain aldehydes and ketones, responsible for undesirable tastes. Genetic inactivation of lipoxygenase is considered the most efficient alternative to reduce the undesirable taste. Thus, to obtain soybean cultivars lacking these enzymes is an interesting method for maintaining the functional properties, contributing to optimize the flavor and increasing their acceptability. This study aimed to obtain soybean genotypes with absence of the enzyme lipoxygenase and present long juvenile period with potential to be used in commercial cultivation in low-latitude regions in the Brazilian Cerrado. The step which analyzed the introduction, growth and soybean development in low latitude was held in Gurupi, TO. The experimental design was a randomized block design with four treatments and four replications. The treatments were BRSMG 790A and BRS 257, food type soybean cultivars intended for food; A 7002 and M 8585, the common type of grain intended for production of oil and meal. They evaluated growth and agronomic components. Growth analysis is effective in evaluating the biological response of soybean food type, when inserted in the lower latitudes. The following steps that included hybridizations, advancement of $F_{1}$ and $F_{2}$ generations were conducted in Brasilia, DF. The crosses were carried out in a greenhouse using parents with long juvenile period and parents with the free-lipoxygenase (intended for consumption as food). The $\mathrm{F}_{1}$ generation was grown in flower beds in the UNB Biology Station. To perform the agronomic evaluations and determination of genetic parameters was installed an experiment, in Água Limpa Farm (ALF), to evaluate plant of the $\mathrm{F}_{2}$ generation. To determine the presence and absence of lipoxygenase analyzes were performed in the laboratory using the colorimetric method, the $\mathrm{F}_{2}$ progeny in height and more than $70 \mathrm{~cm}$. Analysis of genetic components demonstrated high probability of selection gains evidenced by the high heritability values, $\mathrm{CVg} / \mathrm{CVe}$ in $\mathrm{F}_{2}$ populations with a favorable selection for number of days to maturity, plant height, number of pods per plant and yield. However, the high environmental influence difficult selection by pod insertion height. The correlations demonstrated that it is possible to indirect selections of those characters with lower heritability for desirable genotypes. Hybridizations between soybean cultivars with long juvenile period and cultivars freelipoxygenase, originated in the $\mathrm{F}_{2}$ generation, 35 soybean progenies with long juvenile period, taller than $70 \mathrm{~cm}$ and free-lipoxygenase, with potential to be advanced and released as cultivate for the Cerrado region.
\end{abstract}

Key words: Glycine max, soy food, flavor, $\mathrm{F}_{2}$ progenies, genetic components, lipoxygenase. 


\section{SUMÁRIO}

1. INTRODUÇÃO

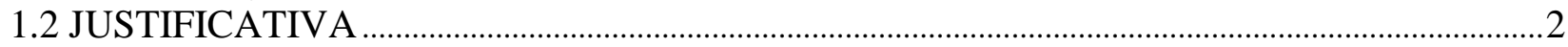

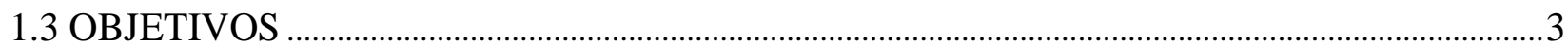

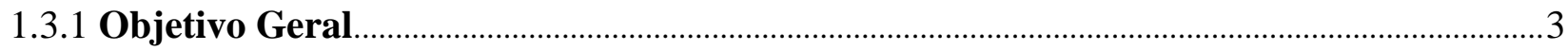

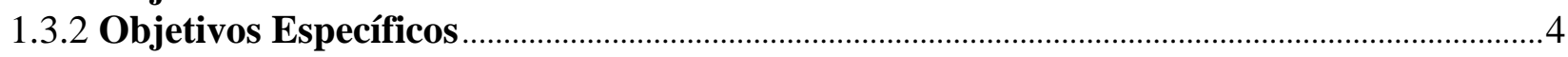

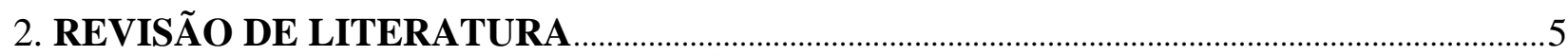

2.1 CLASSIFICAÇÃO BOTÂNICA, GENÉTICA E ORIGEM DA SOJA ...........................................5

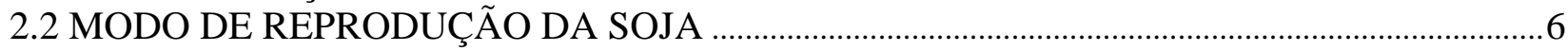

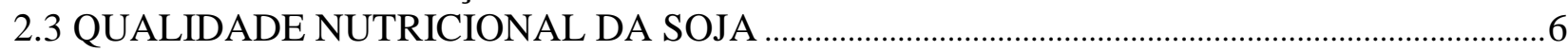

2.4 SOJA PARA ALIMENTAÇÃO HUMANA ………………………………………………………..

2.5 USO DA SOJA NA ALIMENTAÇÃO HUMANA .........................................................................

2.6 CULTIVARES DE SOJA TIPO ALIMENTO ………………………………………………......

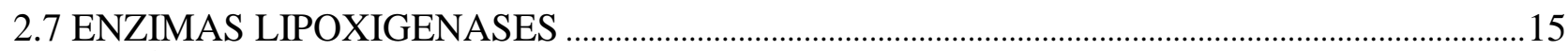

2.8 PERÍODO JUVENIL PARA INDUÇÃO FLORAL ......................................................................19

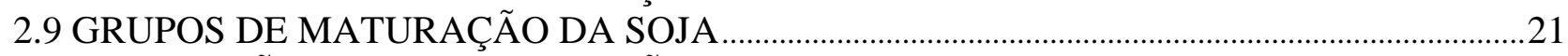

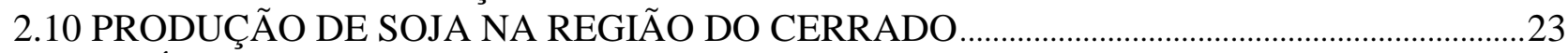

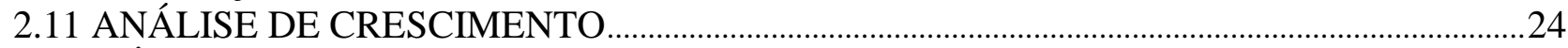

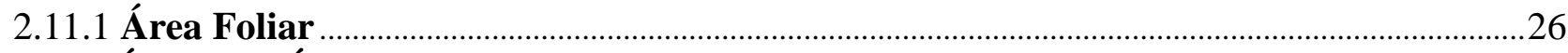

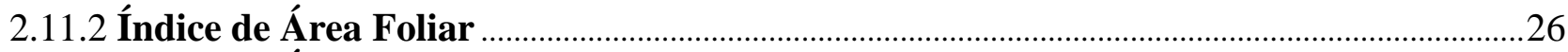

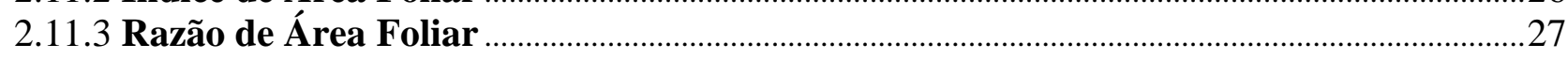

2.11.4 Taxa de Crescimento Absoluto …………………………………………………………...2

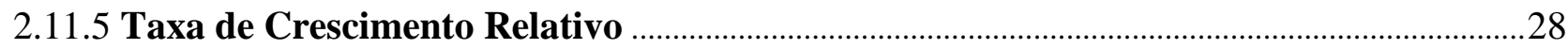

2.11.6 Taxa de Assimilação Líquida

2.12 ETAPAS DO MELHORAMENTO GENÉTICO...........................................................................2

2.12.1 Características Agronômicas Desejáveis para Cultura da Soja ............................................31

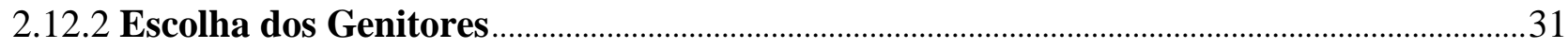

2.12.3 Técnica de Hibridização ………………………………………………………………….....32

2.12.4 Métodos de Condução de População Segregante de Soja ........................................................33

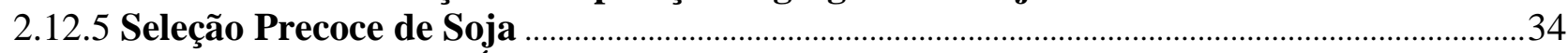

2.13 COMPONENTES GENÉTICOS ……………………………………………………………36

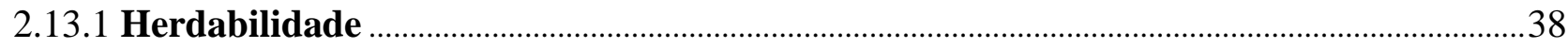

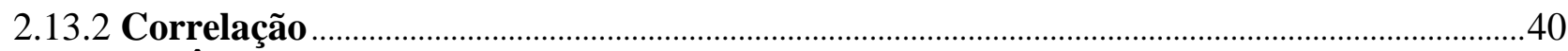

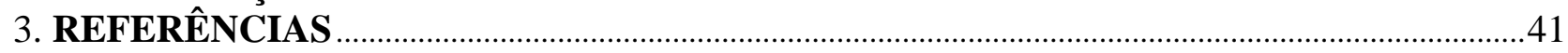

CAPÍTULO I. CARACTERISTICAS AGRONÔMICAS DE SOJA SEM LIPOXIGENASES INTRODUZIDAS EM BAIXA LATITUDES DO ESTADO DO

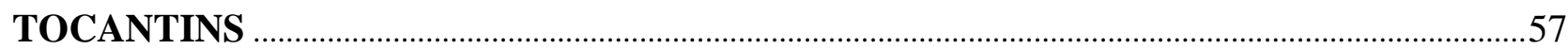

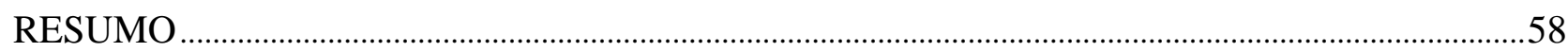

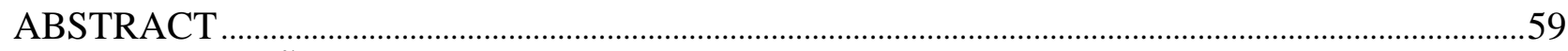

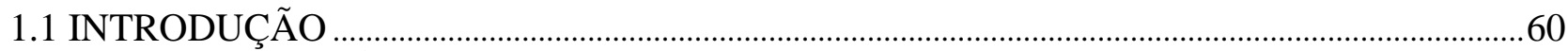

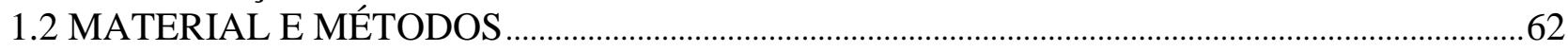




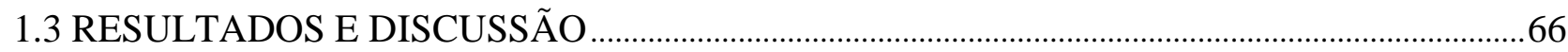

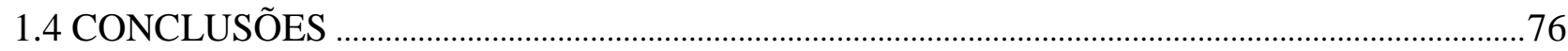

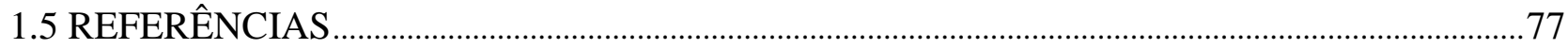

CAPÍTULO 2. PARÂMETROS GENÉTICOS E AVALIAÇÃO AGRONÔMICA EM

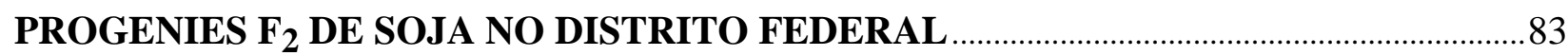

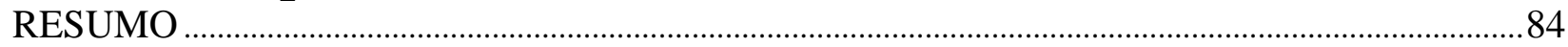

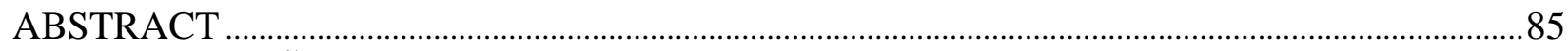

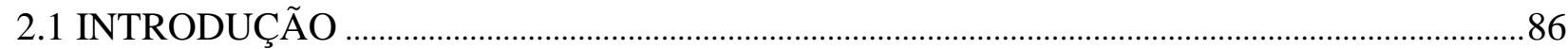

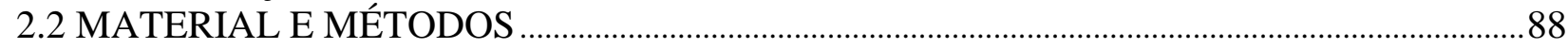

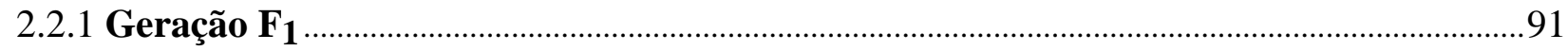

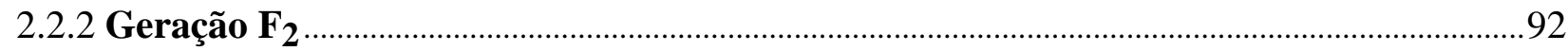

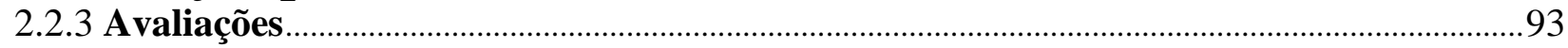

2.2.4 Estatística ………………………………………………………………………93

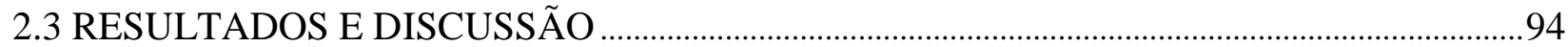

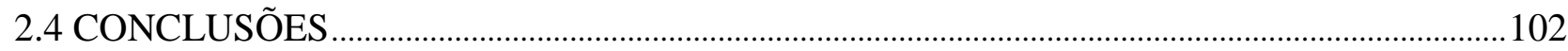

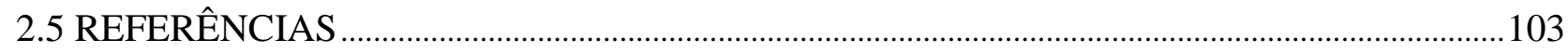

CAPÍTULO 3. DESENVOLVIMENTO DE GENÓTIPOS DE SOJA COM AUSÊNCIA DE LIPOXIGENASES PARA CULTIVO EM BAIXAS LATITUDES ………….........................109

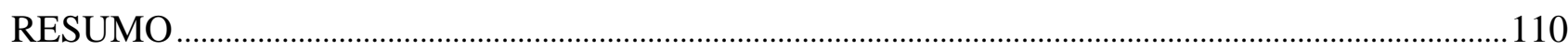

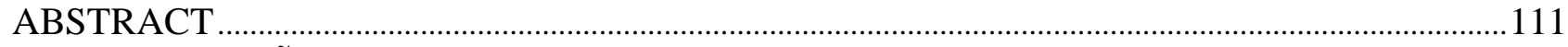

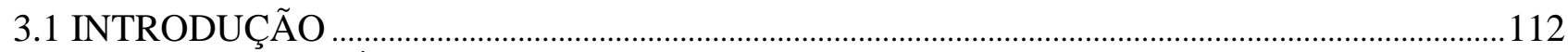

3.2 MATERIAL E MÉTODOS ...............................................................................................................114

3.2.1 Método Colorimétrico ………………………………………………………………………......119

3.2.2 Preparo das Amostras de Soja ……………………………………………………….....119

3.2.3 Preparo do Substrato - Linoleato de Sódio ……………………………………………...120

3.2.4 Preparo da Solução de Beta-caroteno …………………………………………………......120

3.2.5 Preparo do Extrato da Cultivar Kanto 102

3.2.6 Preparo da Solução de Azul de Metileno 0,1 mM..................................................................121

3.2.7 As soluções de tampão fosfato 0,2 M e tampão borato 0,2M ..............................................121

3.2.8 Preparo das Soluções de Lox1 e Lox3 …………………………………………………...121

3.2.9 Teste para Lipoxigenases 1 e 3 ...............................................................................122

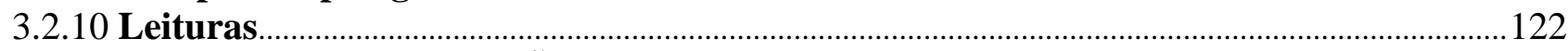

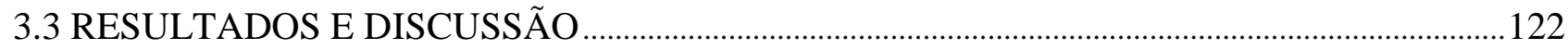

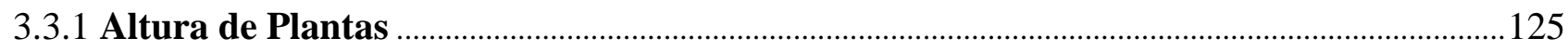

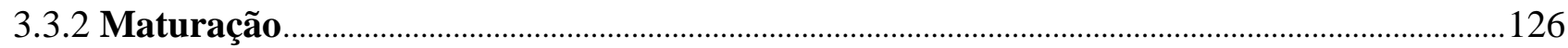

3.3.3 Altura de Primeira Vagem ………………………………………………………………....127

3.3.4 Número de Vagens por Planta ……………………………………………………………….....127

3.3.5 Rendimento de Grãos...............................................................................................................128

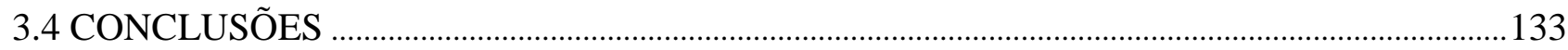

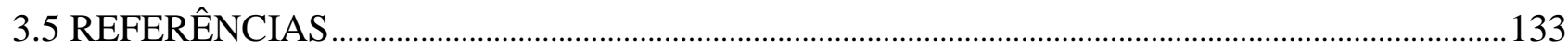




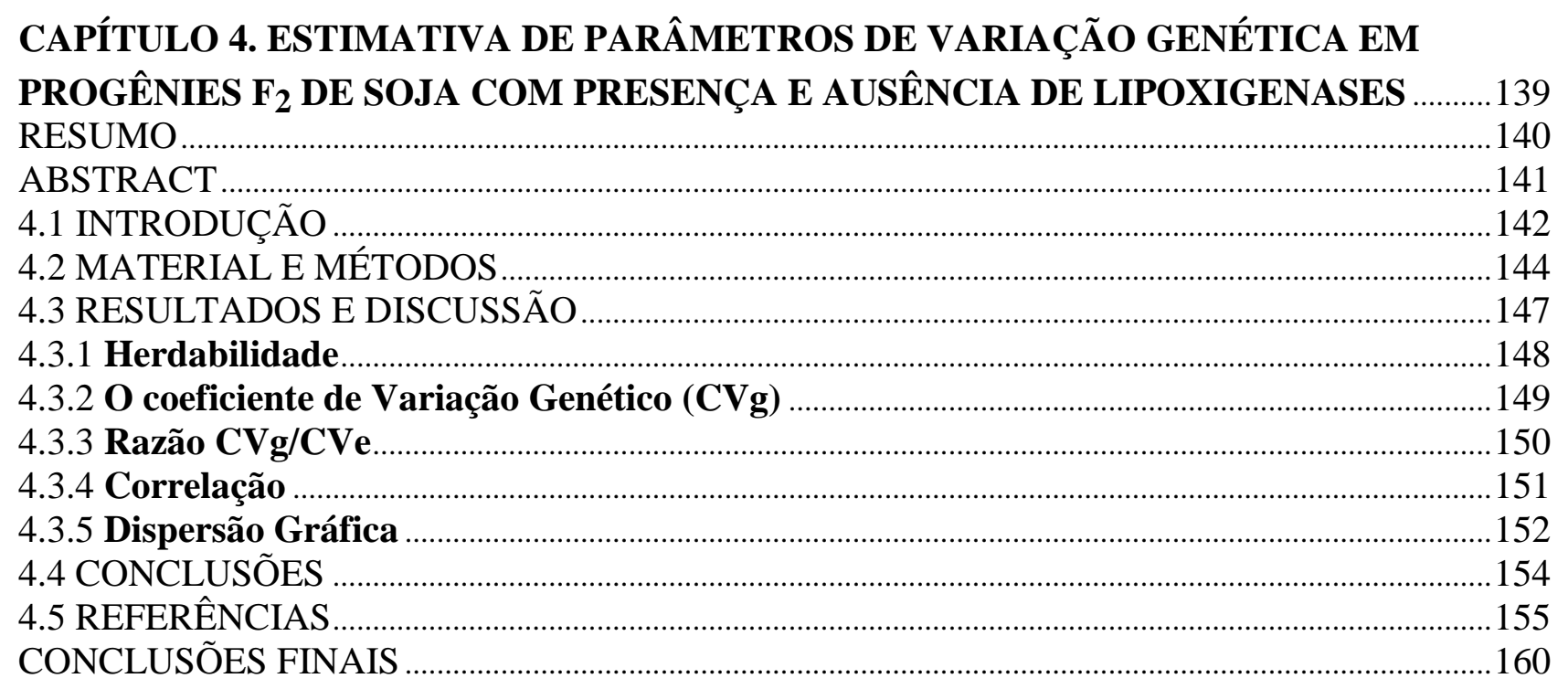




\section{INTRODUÇÃO}

Atualmente o Brasil está na condição de maior exportador mundial do complexo soja. Em 1968 produziu 600 mil toneladas, desde então vêm em uma escala crescente na produção deste grão. Em 1979 passou das 10 milhões de toneladas, em 1989 produziu 24 milhões, em 1998 produziu 31 milhões, em 2003 alcançou 51 milhões de toneladas, na safra 2014/2015 produziu 96 milhões de toneladas apresentando um incremento de $11,5 \%$ em relação à safra passada (MIRANDA, 2005; CONAB, 2015).

No ocidente a soja caracteriza-se, principalmente, como produto para a indústria de alimentação animal. No oriente é há milênios cultivada como alimento humano. Os grãos dessa leguminosa são compostos por aproximadamente $40 \%$ de proteínas e $20 \%$ de lipídios. Apresenta ainda, em sua constituição açúcares, fibras, carboidratos, além de ser fonte de minerais e de vitaminas A, E, B1 e B2 (BELLAVER et al., 2002).

Nos últimos anos, seus subprodutos ganharam espaço considerável no mercado, por suas propriedades nutracêuticas, com numerosas alegações ligando seus efeitos à promoção da saúde (DUFFY et al., 2007). Apesar dos benefícios, muitos consumidores ocidentais evitam alimentos derivados de soja, devido aos sabores indesejáveis os quais são proporcionados pela presença das enzimas lipoxigenases. Essas enzimas têm como função catalisar a adição de oxigênio molecular aos ácidos graxos de reserva da soja, formando compostos voláteis responsáveis pelos sabores comumente referidos como feijão cru ou "beany flavor" (SILVA et al., 2009).

A inativação genética das lipoxigenases é considerada a forma mais eficiente de reduzir o sabor indesejável, uma vez que o tratamento térmico utilizado para inativar essas isoenzimas 
prejudica sensivelmente as proteínas presentes no grão. Assim, a obtenção de cultivares de soja, desprovidas dessas enzimas é o método mais viável por manter as propriedades funcionais, contribuindo para otimização do sabor aumentando sua aceitabilidade (MONTEIRO et al., 2004).

O melhoramento genético das qualidades sensoriais da soja e de seus produtos, combinado com a divulgação dos benefícios à saúde, tem induzido um aumento do consumo pelos brasileiros, estimulando o crescimento do mercado de produtos à base de soja de melhor qualidade. Segmentos de grandes e pequenas indústrias têm desenvolvido produtos á base de soja podendo ser tanto de uso direto como indiretos, via alimentos industrializados (RIGO, 2015).

Atualmente, alguns programas de melhoramento genético vêm desenvolvendo cultivares especiais, visando alimentos mais aceitáveis pelos consumidores brasileiros. Contudo, sua baixa adaptabilidade às diversas áreas de cultivo do Brasil, principalmente, as regiões de baixa latitude é o fator que mais limita a expansão desse tipo de alimento (SANTOS, 2011).

A adaptabilidade de cultivares de soja a determinadas regiões depende das exigências térmicas, hídricas e principalmente fotoperiódicas. A sensibilidade ao fotoperíodo é uma característica variável entre cultivares, nas quais, a faixa de adaptabilidade pode ser restrita ou ampla ao longo das latitudes (HAMAWAKI et al., 2005).

\subsection{JUSTIFICATIVA}

O cultivo da soja, com características desejáveis à alimentação humana ainda é incipiente no Brasil, tendo maior destaque a soja para a indústria. Entretanto, alimentos derivados da soja tem se expandido devido aos teores de proteína e suas qualidades nutracêuticas. Alguns programas de melhoramento têm desenvolvido cultivares especificas com ausência de 2 
lipoxigenase para uso como alimento. Entretanto, quando introduzidas em regiões de menores latitudes reduzem o ciclo, apresentam baixa estatura e rendimento de grãos, restringindo seu cultivo. As poucas cultivares sem lipoxigenase adaptadas às diversas áreas de cultivo do Brasil limitam a produção em baixas latitudes do Tocantins e do Distrito Federal. Essas regiões apresentam localização estratégica, terras agricultáveis e facilidade de escoamento de grãos, o que as potencializam como produtoras de soja especial, do tipo alimento. Em razão da virtual ausência de cultivares desse tipo de soja, aliada ao aumento na demanda, diante da capacidade produtiva dessas regiões, tornam-se necessários estudos que permitam o desenvolvimento de cultivares para ausência de lipoxigenase e adaptadas a baixa latitude.

\subsection{OBJETIVOS}

\subsubsection{Objetivo Geral}

Obter genótipos de soja com ausência das enzimas lipoxigenases e que apresentam período juvenil longo, destinados à alimentação humana e com potencial de serem empregados no cultivo comercial, em regiões de baixa latitude na Região do Cerrado. 


\subsubsection{Objetivos Específicos}

1. Avaliar o crescimento e as características agronômicas de soja sem lipoxigenase introduzida em baixas latitudes do Estado de Tocantins.

2. Realizar estudos sobre parâmetros genéticos e avaliação agronômica em progênies $F_{2}$ de soja no Distrito Federal.

3. Desenvolver genótipo de soja com ausência de lipoxigenases para cultivo em baixas latitudes.

4. Estimar parâmetros de variação genética em progênies $F_{2}$ de soja e genitores com presença e ausência de lipoxigenases. 


\section{REVISÃO DE LITERATURA}

\subsection{CLASSIFICAÇÃO BOTÂNICA, GENÉTICA E ORIGEM DA SOJA}

A soja pertence à divisão Magnoliophyta, classe Magnoliopsida, ordem Fabales, família Fabaceae, subfamília Faboideae, gênero Glycine, espécie Glycine max (L.) Merrill, com 2n=40. A espécie Glycine soja é considerada a mais provável ancestral da qual Glycine max qual teria evoluído. Uma vez que Glycine soja e Glycine max são tetraploides, acredita-se que a forma cultivada tenha derivado de Glycine soja, em razão do acúmulo de características qualitativas e quantitativas resultantes de mutações genéticas sem que houvesse alteração no número de cromossomos (BONETTI, 1981).

A soja tem como origem as regiões central e oeste da China e com o transcorrer dos séculos, teria dispersado a outras regiões e países como o sul da China, Coréia, Japão e sudeste da Ásia. A região central da China foi o centro genético primário da soja. Quando a população local se deslocou para região da Manchúria, por volta de 200 a. c., esta região se tornou em centro genético secundário. Após a domesticação da soja, o seu cultivo cresceu atingindo outros países do oriente. Entretanto, essa cultura permaneceu restrita a esta região por dois milênios e só foi levada para o Ocidente após a chegada dos navegantes europeus ao Oriente, no final do século XV. Por muito tempo a soja permaneceu como uma curiosidade nos jardins botânicos da Inglaterra, França e Estados Unidos (MIRANDA, 2005).

No Brasil essa leguminosa foi introduzida, provavelmente, em 1882 na Bahia. Em 1908, com a chegada dos primeiros imigrantes japoneses, foi introduzida em São Paulo. Em 1914 no 
Rio Grande do Sul, onde apresentou melhor adaptação, face às condições agroclimáticas e de latitude mais semelhantes àquelas de sua origem. Na década de 70, a cultura expandiu à Região Central do Cerrado uma vez que novas variedades foram desenvolvidas e adaptadas às baixas latitudes (CAMPELO et al., 1998; SMALING et al., 2008).

\subsection{MODO DE REPRODUÇÃO DA SOJA}

A soja é uma espécie autógama, com flores perfeitas onde os órgãos masculinos e femininos encontram-se protegidos dentro da corola, sendo sua taxa de polinização cruzada menor que 1\% (BORÉM et al., 1999). A autopolinização, que é a transferência do pólen das anteras para o estigma da mesma flor ou de outra flor da mesma planta, proporciona a autofecundação. A cleistogamia observada em soja é um fenômeno onde os grãos de pólen atingem a maturidade e polinizam o estigma antes da abertura do botão floral condicionando a autopolinização (BORÉM; MIRANDA, 2005).

\subsection{QUALIDADE NUTRICIONAL DA SOJA}

A soja é considerada de alto valor nutritivo e de grande importância na alimentação humana, constituindo excelente fonte de energia e proteína, além de razoável fonte de vitaminas e minerais. Essa leguminosa é composta em média de 18 a $21 \%$ de óleo e 38 a $55 \%$ de proteína contendo a maioria dos aminoácidos essenciais em quantidades aceitáveis. Apresenta ainda 10,9\% de açúcares totais, 6,7\% de fibra e 27 a 30,8\% de carboidratos (BELLAVER et al., 2002). É rica em minerais como magnésio, fósforo, ferro, cobre e zinco. 
Quando ainda verde, apresenta alto conteúdo de niacina e de ácido ascórbico. Quando madura, torna-se ótima fonte das vitaminas A, E, B1, B2 e K sendo uma boa fonte de tiamina, riboflavina e ácido fólico (BELLAVER et al., 2002).

\subsection{SOJA PARA ALIMENTAÇÃO HUMANA}

A soja é uma das culturas de maior importância econômica no mundo sendo cultivada em mais de 80 países. Essa cultura está distribuída em todas as regiões do território brasileiro, com um patamar de crescimento constante, sendo uma das mais importantes commodities brasileira.

De acordo com a Organização Mundial de Saúde, a proteína da soja é a única proteína vegetal que contém todos os aminoácidos essenciais necessários para dar suporte ao crescimento e a manutenção do organismo. Além de melhorar os níveis sanguíneos de colesterol, a soja também é a única alternativa para as pessoas com intolerância à lactose (CARRÃO-PANIZZI; SILVA, 2011; RIGO, 2015).

A soja apresenta propriedades funcionais (nutracêuticas) em seus grãos como as isoflavonas. Diversos estudos demonstram que essa leguminosa pode ser utilizada de forma preventiva e terapêutica em diversos tipos de doenças como cardiovasculares, câncer, osteoporose, além de combater os sintomas da menopausa (AMARAL, 2006; DUFFY et al., 2007).

A soja para fins de utilização pode ser classificada em dois grupos principais: tipo grão (feed) e tipo alimento (food). Na soja comum, tipo grão, as cultivares convencionais geralmente são direcionadas para as indústrias de extração de óleo e o coproduto destas indústrias destinadas a alimentação animal, pois suas características sensoriais não são adequadas para a produção de 
alimentos. A soja tipo alimento é dividida em duas categorias principais, primeiro com sementes pequenas e peso de cem sementes menores que $10 \mathrm{~g}$, destinadas ao consumo em forma de brotos e de "natto"; e sementes grandes com peso de cem sementes igual ou maior que $20 \mathrm{~g}$ destinadas à produção de tofu e extrato hidrossolúvel (CHEN; BUSS, 2004).

No Brasil, o consumo da soja na alimentação humana tem sido restrito, ao contrário do que ocorre em diversos países orientais, onde seu uso tem sido verificado há pelo menos três milênios. No mundo, o principal uso da soja ocorre na forma de óleo e farelo, este último destinado à alimentação animal. Estima-se que $88 \%$ da soja produzida sejam destinadas as empresas esmagadoras, sobretudo, na elaboração de rações para atividades de pecuária, enquanto apenas 5,94\% da soja são destinadas a alimentação humana, na forma in natura (EMBRAPA, 2011).

Atualmente, existem alguns programas de melhoramento genético que vêm desenvolvendo cultivares especiais do tipo alimento, a fim de produzir alimentos mais aceitáveis pelos consumidores brasileiros. Entretanto, devem conter algumas características diferenciadas da soja convencional como boa qualidade sensorial, alto teor de proteínas, maior teor de aminoácidos sulfurados, baixo teor de óleo, melhor digestibilidade, teor reduzido do inibidor de tripsina Kunitz, menor teor ou ausência de enzimas lipoxigenases, grãos claros (tegumento, cotilédone e hilo) e esféricos, grãos graúdos destinados à produção de tofu; sojas de grãos miúdos de hilo, tegumento e cotilédones claros, são destinados à produção de natto. Desenvolvem também, sojas de diferentes colorações de tegumento como preto, verde, marrom, com alto teor de isoflavonas (SEDIYAMA, 2009).

Os primeiros genótipos destinados à alimentação humana, no Brasil, foram introduzidos do Japão e Estados Unidos, a partir deles foram desenvolvidos novos cultivares tipo alimento, 
entretanto, sensíveis ao fotoperíodo, fato que restringe o cultivo desses genótipos as regiões de baixas latitudes no Brasil (MARTINS et al., 2002). E essa ausência de cultivares especiais no mercado, adaptados às diversas áreas de cultivo do Brasil, principalmente, as regiões de baixa latitude é o fator que mais limita a expansão dessa soja do tipo de alimento (SANTOS et al., 2011).

Para expansão do cultivo da soja tipo de alimento, para a região central e norte do Cerrado é necessário que os genótipos contenham características específicas. Além de alta produtividade e resistência a pragas e doenças, devem apresentar tamanhos variados dos grãos conforme usos específicos (YOKOMIZO et al., 2000), bem como sabor agradável, como ausência das enzimas lipoxigenases, e período juvenil longo.

\subsection{USO DA SOJA NA ALIMENTAÇÃO HUMANA}

A soja é um grão muito versátil que dá origem a produtos e coprodutos muito usados pela agroindústria, indústria química e alimentos. Na alimentação humana, a soja compõe vários produtos dentre eles, embutidos, chocolates, temperos para saladas, entre outros produtos (EMBRAPA, 2014; RIGO, 2015). Os produtos da soja podem ser fermentados ou não. A fermentação acrescenta cor, sabor e aroma aos alimentos, além de enzimas e substâncias nutritivas.

A soja, tipo alimento, tem os principais usos:

I. Molho de soja (soy sauce ou shoyu): que é um produto líquido marrom-escuro, fermentado, de gosto salgado, cheiro característico, obtido de soja e trigo fermentados. É um agente de tempero em preparações de alimentos, bem como condimento oriental e também usado 
em outros países. No Japão, é denominado de shoyu. Esse tempero tem sido adotado dentro de várias cozinhas do mundo (HIRAOKA, 2008).

II. Pasta de missô: produto fermentado produzido a partir de uma mistura de soja, arroz e sal marinho. Primeiro é preparado o koji, uma espécie de pasta de arroz cozido, sobre a qual é inoculado um fungo, o Aspergillus oryzae, para que ocorra a fermentação. Depois, a soja (cozida), o sal marinho e a água são acrescentados ao koji. A mistura passa então por uma segunda fermentação, para que ocorra a quebra dos carboidratos e proteínas, até adquirir a consistência desejada. Esse processo pode durar até seis meses, resultando em uma pasta levemente salgada que pode ser usada em sopas, patês, tempero de saladas e refogados (HIRAOKA, 2008).

III. Tempeh: é um alimento feito a partir dos grãos de soja descascados, triturados, cozidos e fermentados pelo fungo Risopus oligosporus com a presença de bactérias e leveduras para adquirem o sabor e o odor característicos que ocorre após 20 a 24 h, à temperatura de $30^{\circ} \mathrm{C}$. Esse é o mais importante alimento fermentado de soja originário da Indonésia e constitui uma das principais fontes de proteínas e vitaminas, devido a ação do fungo, o tempeh ganha significativa dose de vitamina B12, o que é difícil de se encontrar em alimentos de origem vegetal. Depois de pronto apresenta um sabor que lembra ao bacon, é cortado em pequenos tabletes, que podem ser consumidos natural ou fritos (HIRAOKA, 2008).

IV. Natto: alimento obtido da fermentação natural da soja, pela ação de bactérias Bacillus subtilis. O natto possui um odor característico com textura viscosa. Possui ácido linoleico (substância que desintegra o colesterol), sendo um grande aliado da longevidade, com inúmeros benefícios à saúde. Embora seja bem conhecido no Japão, o natto não é frequentemente 
consumido como o misso, devido às suas características (YOKOMIZO et al., 2000, HIRAOKA, 2008).

V. Edamame: ou soja tipo hortaliça, com consumo de grãos obtidos de vagens imaturas, estádio R6; é um preparado feito com grãos de soja ainda dentro da vagem, habitualmente encontrado no Japão, Havaí, China e Coreia. As vagens são fervidas em água junto com condimentos e servidas inteiras (CRANCIANINOV et al., 2005).

VI. Kuromame: soja tipo doce, com grãos maduros de tegumento preto, usados na preparação de doces especiais (YOKOMIZO et al., 2000).

VII. Soja tipo salada: uso dos grãos maduros, de tegumento e hilo de coloração clara, preferencialmente creme ou amarela, em algumas regiões também se usam grãos de cor verde ou variegada, para preparação de saladas mistas, junto com hortaliças e legumes (YOKOMIZO et al., 2000).

VIII. Brotos de soja: alimentos altamente nutritivos, a germinação das sementes de soja promove a redução dos fatores antinutricionais presentes no grão seco, como os inibidores de tripsina e as lectinas, e leva à hidrólise dos oligossacarídeos (rafinose e estaquiose) causadores de flatulência, aumentando assim o valor nutritivo e melhorando a digestibilidade proteica dos grãos germinados (OLIVEIRA et al., 2013).

IX. Tofu: alimento tipo de queijo feito à base de soja, é rico em nutrientes que fazem bem à saúde sendo um ótimo complemento alimentar, é rico em proteínas e minerais, como cálcio, ferro e fósforo. O tofu é resultante da coagulação ou da precipitação das proteínas pela ação, a quente, de sulfato de cálcio ou de magnésio (OETTERER et al., 2006).

X. O extrato hidrossolúvel de soja (EHS): obtido através da seleção, maceração, tratamento térmico, cocção e posterior centrifugação da semente de soja. O EHS constitui boa fonte de 
vitamina B e apresenta proteína de alto valor nutricional. Um quilo de soja fornece cerca de seis a nove litros de EHS. Sua composição química varia em função da matéria-prima utilizada e do processamento empregado. Novos produtos comerciais à base de EHS em combinação com sucos de frutas têm obtido êxito no mercado, indicando que os consumidores podem estar mudando sua atitude em relação aos produtos à base de soja (BEHRENS; SILVA, 2004).

A proteína de soja também é à base de ingredientes de padaria, massas, produtos cárneos, cereais, misturas pré-preparadas, bebidas, alimentação para bebês e alimentos dietéticos. Seu uso mais conhecido é como óleo refinado, obtido a partir do óleo bruto. Nesse processo, também é produzida a lecitina, agente emulsificante, muito usada na fabricação de salsichas, maioneses, achocolatados, entre outros (EMBRAPA, 2014).

\subsection{CULTIVARES DE SOJA TIPO ALIMENTO}

A Empresa Brasileira de Pesquisa Agropecuária desenvolveu, por meio do seu programa de melhoramento genético, algumas cultivares de soja cujas características especiais as tornam adequadas para diferentes utilizações, na alimentação humana. Esses caracteres especiais incluem melhor sabor, ausência de lipoxigenases; alto teor de proteína, 44 - 46\%; grãos graúdos, massa de 100 grãos $\geq 20 \mathrm{~g}$; grãos pequenos, massa de 100 grãos $\leq 10 \mathrm{~g}$; tegumento e hilo amarelos, tegumento preto, e redução de fatores antinutricionais (CARRÃO-PANIZZI, 2001; CARRÃOPANIZZI; SILVA, 2011).

As principais cultivares lançados até hoje por este programa são:

Embrapa 48 - cultivar existente a mais de 15 anos no mercado. Apresenta sabor superior quando comparados com outras cultivares. É usada no processamento de extrato hidrossolúvel de 
soja. No entanto, apresenta ciclo longo e o mercado apresenta necessidade de cultivares mais precoces. Além de ser em média $20 \%$ menos produtiva em relação às cultivares existentes no mercado (SEIBEL et al., 2013).

BRS 213 - cultivar triplo-nulo para enzima lipoxigenase, esta cultivar tem hilo claro, mas quase não encontra mais sementes no mercado, devido a alguns problemas fitossanitários e produtividade. O ciclo também é muito longo para as demandas do mercado de hoje (SEIBEL et al., 2013).

BRS 216 - cultivar com sementes muito pequenas e alto valor proteico, mas a produtividade está em média 30\% menor em comparação com as cultivares do mercado. Entretanto com os grãos pequenos ocorre maior perda na safra (SEIBEL et al., 2013). Foi a primeira cultivar desenvolvida no Brasil com características adequadas para o processamento de natto e para brotos de soja. No processamento de natto, os grãos pequenos permitem maior exposição de superfície facilitando a absorção de água e cozimento. Apresenta também, tegumento e hilo amarelos que são aspectos importantes no processamento de alimentos para melhor coloração no produto final (CARRÃO-PANIZZI; SILVA, 2011).

BRS 257 - cultivar triplo-nulo para enzima lipoxigenase, com produtividade semelhante com as cultivares do mercado. As indústrias de processamento de extrato hidrossolúvel de soja e farinha de soja são muito interessadas neste cultivar (SEIBEL et al., 2013).

BRS 258 - cultivar originado de uma antiga cultivar de soja da Embrapa BR 36. Apresenta ciclo longo para as exigências do mercado atual e uma produtividade inferior, no entanto, o leite de soja e farinha dessa cultivar é bem aceito (SEIBEL et al., 2013).

BRS 267 - cultivar com sementes grandes, sabor doce e ideal para preparar extrato hidrossolúvel de soja e tofu. Também é ideal para ser consumido como hortaliça (Edamame). No 
entanto, apresenta ciclo longo e a produtividade é em média $20 \%$ inferior quando comparada com as cultivares do mercado (SEIBEL et al., 2013).

As cultivares BRSMG 790A e BRSMG 800A foram as últimas lançadas no seguimento alimento, no ano de 2009. A cultivar BRSMG 790A é uma cultivar com características sensoriais, nutricionais e industriais favoráveis ao consumo humano e à indústria de alimentos. Apresenta grãos graúdos, hilo amarelo e sabor suave, apesar de não ser livre de lipoxigenases. Seu grupo de maturidade é 7.9, apresenta resistência à Macha "olho-de-rã", ao Cancro da haste e ao Nematoide de galhas Meloidogyne incognita. Adaptada para as regiões de Minas Gerais, Goiás, Distrito Federal e São Paulo (EMBRAPA, 2009).

A BRSMG 800A é uma cultivar que possui tegumento marrom; após cozimento apresenta características físicas que se assemelham bastante com o feijão "carioquinha". Indicada para alimentação humana, em combinação com feijão ou isoladamente (tipo "tropeiro"). Boa resistência ao acamamento. Grupo de maturidade relativa 8.0 (EMBRAPA, 2009).

Segundo Silva et al. (2009) cultivares de soja direcionadas à alimentação humana para serem recomendadas além das características químicas e físicas, são necessárias análises das características de sabor, as quais são fundamentais para definição de aceitação do produto. Os principais gargalos encontrados na adoção da soja, no mercado interno, e na popularização do seu consumo consiste no sabor exótico ao paladar brasileiro e na falta de tradição do uso desta leguminosa na culinária (CARRÃO-PANIZZI; SILVA, 2011; AGROLINK, 2012).

Apesar de existir varias cultivares de soja destinadas ao uso de alimento, que podem ser utilizadas tanto na dieta em forma de saladas, quanto na indústria de alimentos processados, a cultivar que ainda prevalece com uso na, indústria de alimentos, é a Conquista, que é uma cultivar que não apresenta características especiais alimentação humana (AGROLINK, 2012). 


\subsection{ENZIMAS LIPOXIGENASES}

As lipoxigenases são dioxigenases que contêm um átomo de ferro associado às suas estruturas tridimencionais, responsáveis por catalisar a oxigenação estereoespecífica e a hidroperoxidação de lipídios, contendo uma dupla ligação do tipo cis, cis-1,4-pentadieno em suas estruturas. Os grãos de soja constituem a fonte mais rica de lipoxigenases, essas isoenzimas utilizam os ácidos linoléico e linolênico como substratos formando compostos voláteis de cadeias curtas como aldeídos e cetonas, responsáveis pelos sabores comumente referidos como feijão cru, também denominado de "beany flavor". Resultando em um alimento inaceitável para alguns consumidores que preferem alimentos com sabor suave (SILVA et al., 2009). Além disso, a lipoxigenase tem a capacidade de formar radicais livres que podem atacar outros 34 constituintes, tais como vitaminas, compostos fenólicos e proteínas (ROBINSON et al., 1995).

As lipoxigenases também podem catalisar a co-oxidação dos carotenóides, incluindo $\beta$ caroteno, resultando na perda de nutrientes essenciais, além do desenvolvimento de sabores desagradáveis. Essas enzimas são encontradas em plantas, tecidos de animais, produtos marinhos, cogumelos e outros fungos (ROBINSON et al., 1995). A maioria das lipoxigenases são enzimas solúveis, e algumas são cloroplasmática, mitocondrial, ou localizados nos vacúolos (RIGO, 2015).

Existem vários tipos de lipoxigenases que diferem em suas propriedades. Nas sementes de soja são encontradas nas três formas isoenzimáticas: lipoxigenase 1 (Lox-1), lipoxigenase 2 (Lox-2) e lipoxigenase 3 (Lox-3). A LOX 1 tem atividade ótima em pH 9,0. A LOX 2 tem atividade ótima em $\mathrm{pH}$ 6,5, age mais como um catalisador da auto-oxidação, atuando sobre os triglicérideos 
bem como os ácidos graxos poliinsaturados livres formando além de outros produtos, os ácidos graxos cetodienos e reage com substratos esterificados atacando os triglicerídeos, não necessitando de uma lipase para liberar os ácidos graxos para ter atividade no alimento. E a Lox 3 é semelhante à isoenzima 2, mas a sua atividade é inibida por íons de cálcio, enquanto a lipoxigenase 2 é estimulada pelo metal. Todas as isoenzimas de lipoxigenase de soja são monoméricas e contêm um átomo de ferro por mol de proteína. Sendo que a lipoxigenase é uma proteína ligada a um metal que tem um átomo de ferro em seu centro. Ela é ativada por seu produto e durante a oxidação o $\mathrm{Fe}_{2+}$ passa a $\mathrm{Fe}_{3+}$ (ROBINSON et al., 1995; BAYSAL; DEMIRDÖVEN, 2007; RIGO, 2015).

Segundo Kitamura et al. (1983) as lipoxigenases são codificadas por três genes dominantes, que são herdadas de forma mendeliana simples, sendo que os alelos que determinam a ausência dessas isoenzimas são recessivos. Os locos que controlam a Lox-1 e 2 estão ligados e o loco que controla Lox-3 apresenta segregação independente.

Do total de proteínas presentes no grão de soja, cerca de $1 \%$ são lipoxigenases. Dentre as três lipoxigenases, a Lox-1 é a que apresenta maior atividade "in vitro" e maior estabilidade térmica. As três lipoxigenases de sementes são proteínas monoméricas similares, apresentando pontos isoelétricos distintos. As massas moleculares das Loxs são, respectivamente, 94.038, 97.035 e 96.541 Da (GALLIARD; CHAN, 1980).

Em algumas leguminosas o "beany flavor" pode ser prontamente controlado por inativação rápida da lipoxigenase com tratamento térmico, álcool ou tratamento com ácido. Menos de 1\% da atividade original da lipoxigenase permanece após a imersão dos grãos em 30 a $80 \%$ de álcool. Mas o tratamento térmico é o mais usado para melhorar as características sensoriais da soja, este tratamento, deve ser controlado para evitar destruição de aminoácidos importantes, 
insolubilização de proteínas, e diminuição da biodisponibilidade de outros nutrientes. Com o branqueamento é possível prevenir a ação dessas enzimas, melhorando a aceitação dos produtos derivados da soja (VASCONCELOS et al., 2001; FELIX et al., 2011; RIGO, 2015).

A inativação genética das lipoxigenases é considerada a forma mais eficiente de reduzir o "beany flavor", uma vez que o tratamento térmico utilizado para inativar essas isoenzimas, prejudica sensivelmente às proteínas presentes no grão. Assim, a utilização de cultivares de soja desprovida dessas enzimas é o método mais viável, por dispensar o tratamento térmico e manter as propriedades funcionais contribuindo para otimização do sabor aumentando sua aceitabilidade (MONTEIRO et al., 2004).

No Brasil, uma das primeiras variedades de soja com ausência das três lipoxigenases denominadas triplo nulo $(\mathrm{TN})$, foi desenvolvida pelo programa de melhoramento genético da Universidade Federal de Viçosa com a variedade FT-Cristalina RCH TN, portadoras dos três pares de alelos homozigotos recessivos (lox1lox1lox2lox2lox3lox3), sendo resultante de cruzamentos da FT-Cristalina com as variedades Ichigowase (sem Lox 3) e PI 86023 (Lox 2 ausente), intercruzada e posteriormente cruzadas com uma linhagem sem as três isoenzimas no Japão (MARTINS et al., 2002). Após a obtenção dessa linhagem, várias cultivares TN foram desenvolvidas com a mesma característica como pode ser observado no Quadro 1 (EMBRAPA, 2003). 
Quadro 1. Principais cultivares de soja com ausência de lipoxigenages lançadas pela UFV e seus respectivos genitores

\begin{tabular}{|c|c|}
\hline UFVTN 101 & FT Cristalina $^{3} \times\left\{\left[\left(\text { FT Cristalina }^{3} \times \text { Ichigowase }\right) \times \text { PI } 86023\right]^{2} \times\right.$ Kyushi 111$\}$ \\
\hline UFVTN 102 & CAC $13 \times\left\{\left[\left(\text { FT Cristalina }^{3} \times \text { Ichigowase }\right) \times \text { PI 86023 }\right]^{2} \times\right.$ Kyushi 111$\}$ \\
\hline UFVTN 103 & IAC $123 \times\left\{[(\text { FT Cristalina3 } \times \text { Ichigowase }) \times \text { PI } 86023]^{2} \times\right.$ Kyushi 111$\}$ \\
\hline UFVTN 104 & FT Cristalina $^{3} \times\left\{\left[\left(\text { FT Cristalina }^{3} \times \text { Ichigowase }\right) \times \text { PI 86023 }\right]^{2} \times\right.$ Kyushi 111$\}$ \\
\hline UFVTN 105 & CAC $16 \times\left\{\left[\left(\text { FT Cristalina }^{3} \times \text { Ichigowase }\right) \times \text { PI } 86023\right]^{2} \times \text { Kyushi } 111\right\}^{2}$ \\
\hline
\end{tabular}

Fonte: Miranda (2005)

Se por um lado as lipoxigenases causam sabor desagradável aos grãos, por outro elas tem função fisiológica secundarias nas plantas como na biossíntese de compostos regulatórios, no crescimento e desenvolvimento da planta, senescência, germinação das sementes, resposta a ferimento, reserva vegetativa e resistência a insetos e patógenos. Quando ocorre um estresse por danos físicos às células uma degradação sequencial de lipídeos pode ser iniciada pelas enzimas lipoxigenases. Essas formam hidroperóxidos de ácidos graxos, que são rapidamente metabolizados para formar vários produtos como a traumatina, envolvida na resposta a ferimentos e na indução da divisão celular para formação de calos, o ácido jasmônico, associado à ativação de genes que codificam a síntese de proteínas de reserva e inibidores de proteases, os aldeídos voláteis e oxiácidos, causam efeito inibitório sobre o crescimento de fungos patogênicos, insetos e protozoários (SILVA et al., 2001).

Embora a utilização de cultivares de soja isentas das enzimas de lipoxigenases seja a alternativa mais eficaz para aumentar a produção da soja tipo alimento, seu cultivo fica restrito as regiões sul e sudeste e Goiás. Não existe cultivares tipo alimento adaptadas as regiões de menores latitudes como demostrado nos trabalhos de Santos et al. (2011) e Santos (2005) realizados nos estados de Tocantins e Paraíba. As cultivares existentes, quando introduzidos em menores 
latitudes, apresentam baixa estatura e rendimento, principalmente em decorrência da sensibilidade fotoperiódica, o que inviabiliza o cultivo comercial.

\subsection{PERÍODO JUVENIL PARA INDUÇÃO FLORAL}

O tempo compreendido entre a emergência da plântula até o dia em que ela estará apta a receber o estimulo para indução floral, é definido como período juvenil. As cultivares de período juvenil curto são aquelas cujo estimulo para florescer pode ser verificado a partir das folhas unifolioladas ou primeiras folhas trifolioladas. Nesse caso as plantas atingem altura e produtividade satisfatória somente quando semeadas em épocas em que o comprimento do dia é maior do que seu fotoperíodo crítico (SPEHAR et al., 1993).

As cultivares de período juvenil longo (PJL) são aquelas cujo estimulo para florescer é verificado mais tardiamente, ou seja, a partir da emissão da $5^{\mathrm{a}}$ a $7^{\mathrm{a}}$ ou posterior folha trifoliolada, mesmo cultivada sob condições de dias curtos. Geralmente essas cultivares atingem altura adequadas em ampla época de semeadura. A maioria das cultivares adaptadas a região CentroNorte do Brasil apresentam o período juvenil longo (SEDIYAMA, 2009).

Por ser uma planta de dias curtos, a maior parte da área mundial cultivada com a cultura da soja está localizada em latitudes maiores que $30^{\circ}$. As cultivares convencionais são, na grande maioria, altamente sensíveis as mudanças entre latitudes ou datas de semeadura devido às suas respostas às variações no fotoperíodo. Assim, a adaptação de um cultivar de soja depende não somente das exigências térmicas e hídricas, mais principalmente a fotoperiódica. Nas regiões tropicais, onde o fotoperíodo é mais curto durante a estação de crescimento da soja, ocorre 
redução no período vegetativo, ocasionando o florescimento precoce, consequentemente, causando reduções no porte das plantas e na produtividade (ALMEIDA et al., 1999).

A sensibilidade fotoperiódica é uma característica variável, onde cada cultivar apresenta um fotoperíodo crítico, sob o qual se desenvolve vegetativamente de maneira adequada. Assim, o florescimento da soja ocorre quando o fotoperíodo do ambiente de cultivo passa a ter valor inferior ao crítico da cultura (FIELTZ; RANGE, 2004).

A característica de juvenilidade longa foi à solução para retardar o florescimento da soja em condições de dias curtos, assim cultivares que apresentam essa característica não são induzidas a florescer na fase juvenil, mesmo quando submetida ao fotoperíodo bem curto, o que permite maior crescimento vegetativo. O controle do florescimento e consequentemente do porte da planta, representa um fator básico a ser considerado no melhoramento para o desenvolvimento de cultivares menos sensíveis às variações de data de semeadura e com adaptação em faixas de latitudes mais baixas.

O período juvenil longo é condicionado por dois genes recessivos que podem ser influenciados por outros eventos genéticos na planta. No trabalho realizado por CarpentieriPípolo et al. (2002) na descendência da cultivar Paraná e Bossier, foi constatado que a herança para PJL é condicionada por dois genes, sendo que a floração tardia é condicionada pelos dois genes quando estão presentes na forma recessiva por epstasia dupla. Em função dessa característica, a faixa de adaptabilidade de cada cultivar se amplia ao longo das latitudes. Assim, cultivares PJL podem ser cultivadas em áreas abrangentes de latitudes (HAMAWAKI et al., 2005).

Os trabalhos de adaptação da soja para regiões de menores latitudes tiveram início no Instituto Agronômico de Campinas e no Centro Nacional de Pesquisa de Soja em 1970, com o 
desenvolvimento de populações entre cruzamentos de cultivares americanas com genótipos possuindo característica de PJL. Onde vários genótipos com essa característica foram identificados e usados no desenvolvimento de novas cultivares. Inicialmente, foram utilizados os genótipos Santa Maria (Karutoby), PI 159925 e PI 240664. Posteriormente, foram identificadas e selecionadas mutações naturais, expressando grau variado de juvenilidade, como IAC73-2736, OCEPAR 9, Paranagoiana, Doko-pjl, Savanão, BR-1-pjl, entre outras que ocorreram em várias cultivares, sendo então utilizadas como progenitores nos cruzamentos para a geração de cultivares de diferentes grupos de maturação, em ambientes de baixas latitudes (ALMEIDA; KIIHL, 1998). As primeiras cultivares desenvolvidas e indicadas para essas áreas foram Tropical, Timbira, BR-10 (Teresina) e BR-11 (Carajás) (KIIHL et al., 1986 citado por ALMEIDA et al., (1999).

\subsection{GRUPOS DE MATURAÇÃO DA SOJA}

O ciclo da soja é determinado pelo número de dias da emergência até a maturação das vargens, que pode variar de 70 a 200 dias, dependendo do local e época de semeadura. O fotoperíodo e a temperatura são os principais fatores abióticos que influenciam o desenvolvimento da cultura da soja, que é uma planta de dias curtos. A temperatura geralmente tem influência positiva sobre a taxa de desenvolvimento da cultura. A sensibilidade ao fotoperíodo, no entanto, pode modificar essa resposta, assim, uma planta de dias curtos floresce quando os dias encurtam (SETIYONO et al., 2007).

Nos Estados Unidos, o ciclo da cultura da soja é definido por grupos de maturação, que abrange as diferentes regiões. No total são 13 grupos de maturação que inicia pelas cultivares 
mais precoces 000, 00, 0, I, II, III, IV, V, VI, VII, VIII, IX e X. Geralmente a maioria das cultivares pertencente a cada grupo de maturação é adaptada a uma faixa de latitude de 160 a 240 $\mathrm{km}$. Na região de latitude maior que a considerada, as cultivares apresentam florescimento mais tardio que o normal. Em latitudes menores que a da região considerada, as cultivares terão uma maturação mais precoce. A faixa de maturação dentro de cada grupo pode variar de 10 a 15 dias (SEDIYAMA, 2009).

No Brasil, os grupos de maturação variam de 5 a 10, 5.0 para o extremo do Rio Grande do Sul e 10.0 para Roraima. Quanto maior o número, mais próximo ao Equador será sua região de adaptação (PENARIOL, 2000). Como base de comparação é usada uma cultivar padrão para cada grupo de maturação. As demais cultivares são classificadas em maturação, em relação a esta cultivar padrão (SEDIYAMA, 2009).

Pode se dizer que, para cada aumento de número depois do ponto teremos de 1,5 a 2 dias a mais de ciclo da soja. Assim uma variedade 8.9 tem um ciclo mais longo que uma 8.7. Cada grupo de maturação se ajusta melhor em determinada faixa de latitude, em função de sua resposta ao fotoperíodo, variando de acordo com a quantidade de horas/luz a que é exposta. Para a soja, quanto menor a quantidade de luminosidade, mais rapidamente entrará na fase reprodutiva, encurtando assim seu ciclo e reduzindo a altura das plantas. Então, ao localizarmos uma cultivar de grupo de maturação 9.0 no sul do Brasil, este material alongará seu ciclo de forma a comprometer totalmente sua produtividade (PENARIOL, 2000).

As empresas que desenvolvem cultivares de soja, no Brasil, passaram a adotar, a classificação internacional de grupos de maturação. Com base em resultados experimentais em todas as regiões brasileiras de cultivo, e com critério comparativo, enquadrou-se todas as cultivares nesta nova definição. A M-soy adota após a sigla da empresa, os dois primeiros 
números significam o seu grupo, e os dois seguintes diferenciam as cultivares, assim a cultivar M-SOY 8080RR pertence ao grupo 8.0 de maturação. As cultivares da Agroeste, são identificadas da seguinte forma: AS 3707 IPRO. AS = Sigla da marca Agroeste; O primeiro número identificará a cultura: 3= Soja. Para os dois dígitos centrais representam o Grupo de Maturação. O quarto dígito é livre para identificar alguma resistência à doença e/ou característica diferenciada (RODRIGUES et al., 2001; BASTIDAS et al., 2008; AGROESTE, 2014).

\subsection{PRODUÇÃO DE SOJA NA REGIÃO DO CERRADO}

O Brasil é o segundo país produtor de soja, ficando atrás somente dos Estados Unidos da América. Na safra 2014/2015, no Brasil, foram cultivadas aproximadamente 31,9 milhões de hectares dos quais 18,8 milhões localizaram-se na região de cerrados e na região norte-nordeste do país correspondendo a mais $65,8 \%$ da área produtora nacional, apresentando uma produtividade média de $2.861 \mathrm{t} \mathrm{ha}^{-1}$. A produção dessa oleaginosa nessa safra foi superior a 96 milhões de toneladas apresentando um incremento de $11,5 \%$ em relação a safra passada (CONAB, 2015). Estima-se ainda que a região que abrange os estados de Mato Grosso, Goiás, Mato Grosso do Sul, Bahia, Minas Gerais, Maranhão, Tocantins, Piauí, Rondônia, Pará e Distrito Federal possa aumentar a produtividade em mais de 50 milhões de toneladas de soja nos próximos anos (EMBRAPA, 2013). Esses resultados positivos em relação à produção de soja, no Brasil, é fruto de estudo, desenvolvimento, seleção e recomendação de cultivares de soja adaptadas à região de menores latitudes (LIMA et al., 2008).

A cultura da soja se expandiu a partir dos anos 1960 , em latitudes entre $30^{\circ} \mathrm{S}$ e $20^{\circ} \mathrm{S}$, principalmente nos estados do Rio Grande do Sul, Santa Catarina, Paraná e São Paulo, com a 
introdução de cultivares e linhagens americanas, pois até a década de 1970 o cultivo restringia-se à região sul do País. A partir dos anos 1980, com a criação de cultivares incorporando PJL, a exemplo da cultivar Doko, a soja expandiu para a região do Cerrado (SPEHAR, 1995), ocupando inicialmente o Triângulo Mineiro, Mato Grosso do Sul, Mato Grosso, Goiás. Depois, abrangeu o Tocantins, sul do Maranhão, sul do Piauí e oeste da Bahia, tornando a região do cerrado a maior produtora de soja do país (CISOJA, 2009; EMBRAPA, 2013).

Somente no ecossistema do Cerrado cerca de 100 milhões de hectares foram transformados em áreas aptas para o cultivo da soja e outras culturas (HAMAWAKI et al., 2005). Essa expansão foi favorecida pelo desenvolvimento de cultivares de soja adaptadas às zonas equatoriais. Para isso, os melhoristas procuraram manter o mesmo tipo de soja utilizada no sul do país, alterando, principalmente, a resposta ao fotoperíodo, através da introdução de genes que retardam o florescimento em condições de dias mais curtos (MIRANDA, 2005).

Esse cenário produtivo da região do Cerrado demostra a grande capacidade de produção de soja. Entretanto, há predominância absoluta do tipo comum, com grão destinado à produção de óleo e farelo. Contudo, existe grande potencialidade de inserção do cultivo de soja do grupo especial, destinados à alimentação humana.

\subsection{ANÁLISE DE CRESCIMENTO}

As técnicas de análise de crescimento foram desenvolvidas, no início do século XX, por pesquisadores britânicos que apresentaram as fórmulas e derivações necessárias ao seu uso. A análise quantitativa de crescimento tem sido usada, na tentativa de explicar diferenças no crescimento, de ordem genética ou ambientais descrevendo as condições morfofisiológicas das 
plantas, em diferentes intervalos de tempo, permitindo acompanhar a dinâmica da produtividade por meio de índices fisiológicos e bioquímicos (MAGALHÃES, 1979).

O fundamento da análise de crescimento é a medida sequencial da acumulação de matéria orgânica na planta, sendo que a sua determinação é feita, normalmente, considerando a massa da matéria seca ou a sua fitomassa (MAGALHÃES, 1979). Por este procedimento ser destrutivo, as plantas amostradas em cada tempo, devem representar a população em estudo.

A coleta de dados da massa da matéria seca das diferentes partes da planta é simples e exige poucos equipamentos como: réguas graduadas em milímetros, tesouras, paquímetro, estufas de aeração forçada, sacos plásticos, sacos de papel etc. Dispensam laboratório e material sofisticado, o que é considerado uma vantagem, determinando-se massa da matéria seca da planta inteira ou parte dela e área foliar, obtidas a intervalos de tempo regulares (BENINCASA, 2004). A partir dos dados de crescimento pode-se inferir sobre atividade fisiológica, e estimar de forma bastante precisa, as causas de variações de crescimento entre plantas geneticamente diferentes ou entre plantas crescendo em ambientes diferentes.

Do ponto de vista agronômico, a análise de crescimento, permite conhecer diferenças funcionais e estruturais entre cultivares de uma mesma espécie para estudo do desenvolvimento vegetal sob diferentes condições ambientais de cultivo. Possibilita selecionar cultivares ou espécies que apresentem características funcionais mais apropriadas ao cultivo (PEIXOTO et al., 2011).

As medidas obtidas ao longo do ciclo da cultura, em plantas intactas ou colhidas, são tabuladas podendo ser analisadas por fórmulas matemáticas e/ou graficamente utilizando-se várias funções, equações ou programas. Equação de regressão não só corrige as oscilações 
normais, como permite avaliar a tendência do crescimento em função dos tratamentos (BENINCASA, 2004).

\subsection{1 Área Foliar (AF)}

A medida da área foliar está relacionada com a determinação ou estimativa da superfície fotossinteticamente ativa da planta que, com exceções, são as folhas, os órgãos vegetais responsáveis pela fotossíntese e essa superfície foliar pode ser determinada direta ou indiretamente (PEIXOTO et al., 2011).

A área foliar pode ser determinada por diferentes métodos. A maioria com alto grau de precisão. Dentre estes métodos, destacamos: massa seca de discos foliares, onde com um perfurador de área conhecida, através de punções, tomam-se amostras de discos foliares, geralmente dez, a partir da área e peso conhecido dos discos, relaciona-os com a massa seca total das folhas, a partir desse método conhece-se a área foliar total da planta.

\subsection{2 Índice de Área Foliar (IAF)}

A área foliar (AF) de uma planta constitui sua matéria prima para fotossíntese sendo muito importante na produção de carboidratos, lipídios e proteínas. O índice de área foliar (IAF) representa a área foliar total por unidade de área do terreno e funciona como indicador da

superfície disponível para interceptação luminosa. Um IAF igual a 2,0 significa $2 \mathrm{~m}^{2}$ de área foliar ocupando $2 \mathrm{~m}^{2}$ de solo (S): Assim o IAF = AF / S (PEIXOTO et al., 2011). 
O IAF pode variar com a população de plantas, distribuição e variedades. Existe um IAF ótimo para cada cultura, que varia geralmente de 2,0 a 5,0. Isto por que durante o crescimento da população vegetal o IAF deve ser suficiente para interceptar o máximo de luz (PEIXOTO; PEIXOTO, 2004).

\subsubsection{Razão de Área Foliar (RAF)}

A Razão de área foliar (RAF) representa a relação entre a área foliar (L) e o peso da matéria seca total da planta (W). Também denominado de quociente de área foliar RAF = L/W ou (L1 +

$\mathrm{L} 2) /(\mathrm{W} 1+\mathrm{W} 2)$; expressa-se em $\mathrm{cm}^{2} \mathrm{ou} \mathrm{dm}^{2} \mathrm{~g}^{-1}$. A RAF declina enquanto a planta cresce, em função do autossombreamento, com a tendência da diminuição da área foliar útil ou fotossinteticamente ativa, para a produção de matéria seca (BENINCASA, 2004).

\subsubsection{Taxa de Crescimento Absoluto (TCA)}

A taxa de crescimento absoluto é a variação ou incremento entre duas amostras sucessivas. Essa medida pode ser usada para se ter ideia da velocidade média de crescimento ao longo do período de observação. TCA $=(\mathrm{W} 2-\mathrm{W} 1) /(\mathrm{T} 2-\mathrm{T} 1)=\mathrm{g} \mathrm{dia}^{-1}$ ou semana. Onde, W1 e W2 é a variação da massa da matéria seca em duas amostras consecutivas tomadas nos tempos T1 e T2. Indica a variação de crescimento em um determinado intervalo de tempo; ou um incremento de matéria seca neste intervalo de tempo. (PEIXOTO; PEIXOTO, 2004). 


\subsubsection{Taxa de Crescimento Relativo (TCR)}

Esta medida é apropriada para avaliação do crescimento vegetal, que é dependente da quantidade de material acumulado gradativamente. A TCR expressa o incremento na massa de matéria seca, por unidade de peso inicial, em um intervalo de tempo (REIS; MULLER, 1979).

Para valores médios, usa-se: $\mathrm{TCR}=(\ln \mathrm{W} 2-\ln \mathrm{W} 1) /(\mathrm{T} 2-\mathrm{T} 1)=\mathrm{g} \mathrm{g}^{-1} \mathrm{dia}^{-1}$, onde ln é o logaritmo neperiano; W1 e W2 representam a massa da matéria seca nos tempos T1 e T2.

A taxa de crescimento relativa pode ser considera como a medida mais apropriada para avaliação do crescimento vegetal, que é dependente da quantidade de matéria que está sendo acumulado. A TCR varia ao longo do ciclo da planta, pois depende de dois outros fatores do crescimento: a área foliar útil para a fotossíntese ou razão de área foliar (RAF), e da taxa fotossintética bruta, descontando a respiração, mais a fotorrespiração nas plantas C3, ou taxa de assimilação líquida (TAL) (BENINCASA, 2004).

\subsubsection{Taxa de Assimilação Líquida (TAL)}

A taxa de assimilação liquida (TAL) representa o balanço entre a matéria produzida pela fotossíntese e aquele perdido pela respiração, indicando a eficiência de uma planta na produção de matéria seca (PEREIRA; MACHADO, 1987).

A TAL reflete a dimensão do sistema assimilador que é envolvida na produção de matéria seca, ou seja, é uma estimativa da fotossíntese líquida. Essa taxa depende dos fatores ambientais, principalmente da radiação solar. Em decorrência do autossombreamento a TAL diminui com o aumento do IAF e, consequentemente, com o crescimento da população de plantas 
(BENINCASA, 2004). A TAL expressa em $\mathrm{g} \mathrm{cm}^{-2} \mathrm{dia}^{-1}$ ou $\mathrm{g} \mathrm{dm}^{-2} \mathrm{dia}^{-1}$, sendo $\mathrm{TAL}=(\mathrm{W} 2$ $\mathrm{W} 1)(\operatorname{lnL} 2-\operatorname{lnL} 1) /(\mathrm{L} 2-\mathrm{L} 1)(\mathrm{T} 2-\mathrm{T} 1)$.

Diversos estudos que aplicaram a análise de crescimento para inferir o crescimento e o desenvolvimento de plantas oleaginosas como a soja (CRUZ, 2007), mamoneira (SILVA, 2008), e girassol (SOUZA, 2010), evidenciaram que em todas as culturas, os índices fisiológicos permitiram identificar o potencial de adaptação e produtivo dos genótipos estudados, sob as diferentes condições ambientais.

\subsection{ETAPAS DO MELHORAMENTO GENÉTICO}

Melhoramento de plantas pode ser definido como, a ciência e a arte de aprimorar plantas (FEHR, 1987). O melhoramento genético da soja é um processo contínuo de desenvolvimento de cultivares, com a pesquisa assentados em objetivos gerais e específicos, visando à solução das limitações reais ou potenciais do cultivo frente aos fatores bióticos e abióticos que interferem na produção da soja (ALMEIDA et al., 1999). Para Bespalhok et al. (2007) a hibridação artificial em espécies autógamas tem como objetivo reunir em uma nova linhagem pura, alelos favoráveis presentes em duas ou mais cultivares comerciais, linhagens elites de programas de melhoramento, acessos introduzidos ou espécies relacionadas.

Atualmente, o principal objetivo dos programas de melhoramento genético é a seleção de genótipos de soja com elevada produtividade de grãos e capacidade de adaptação ambiental, que estão aliadas com a predição dos ganhos obtidos por seleção (FARIA et al., 2007). Para obtenção de uma cultivar de soja, além de produtiva, é necessário apresentar comportamento estável em uma série de ambientes (KIIHL; ALMEIDA 2000). 
Grande parte dos programas de melhoramento envolvem as seguintes etapas: 1) escolha de genitores complementares e contrastantes, ou que possuam características especifica; 2) hibridação entre os progenitores e obtenção da população segregante; 3) escolha do método de condução da população segregante mais adequado, para obter resultados esperados; 4) teste de desempenho agronômico e 5) seleção das linhagens experimentais. A etapa intermediária, correspondente ao avanço das gerações para atingir a homozigose, é feita de forma rotineira, com a desvantagem do aumento do tempo para cada ciclo do programa de melhoramento e a demanda adicional de recursos humanos e financeiros. Essas limitações poderiam ser contornadas pela eficiente escolha dos genitores e avaliação e seleção de progênies promissoras em gerações iniciais, identificando incompatibilidade híbrida e diferenças na capacidade de combinação levando à ocorrência de cruzamentos inferiores (MACHADO, 1999; BORÉM; MIRANDA, 2009).

Selecionar progênies superiores não é tarefa fácil, uma vez que os caracteres de importância, em sua maioria são quantitativos e apresentam comportamento complexo, por serem influenciados pelo ambiente e estarem inter-relacionados, de tal forma que a seleção de um provoca uma série de mudanças em outros. Para a obtenção de genótipos superiores, é necessária a reunião de uma série de atributos favoráveis que confiram rendimento comparativamente mais elevado e satisfaçam as exigências do mercado. Com isso, a seleção baseada em uma ou poucas características pode mostrar-se inadequada, conduzindo a um produto final superior apenas em relação aos caracteres selecionados (CRUZ; REGAZZI, 1997). 


\subsubsection{Características Agronômicas Desejáveis para Cultura da Soja}

No Brasil, os programas de melhoramento genético de soja, visam principalmente o aumento da produtividade de grãos e resistência às doenças que causam maiores perdas na produtividade. Porém, outros caracteres são fundamentais para inserção no sistema produtivo, considerando-se ciclo, altura de plantas na maturação, altura de inserção, acamamento e valor agronômico, resistência a deiscência de vagem, resistência às doenças, resistência a pragas, resistência a nematóides, resistência a chuva na colheita, qualidade de grãos (FINHOLDT, 2012).

A altura de plantas 60 e $120 \mathrm{~cm}$ permitindo colheita mecanizada é determinística na seleção (REZENDE; CARVALHO, 2007). A altura de primeira vagem deve localizar-se em torno de 10 a 12 cm, e a altura mais satisfatória está em $15 \mathrm{~cm}$ em situações de topografias mais acidentadas.

\subsubsection{Escolha dos Genitores}

No melhoramento de soja, quando se deseja obter populações segregantes, uma das dificuldades é a definição dos genitores. Nesse processo é de fundamental importância o conhecimento das limitações da cultura, definindo a escolha inicial de genitores, que possuam características de interesse superiores (ALMEIDA, 2008).

Considerando que ausência de lipoxigenase e período juvenil longo são características oligogênicas, seria lógico inferir que alguns cruzamentos entre as respectivas fontes de variação seriam suficientes para recuperar recombinantes desejáveis. Contudo, espera-se que interações e ligações gênicas façam com que haja especificidade entre genitores (ST MARTIN et al., 2009). 
Daí a importância de se avaliarem progênies provenientes de cruzamentos entre genitores com base genética distinta.

\subsubsection{Técnica de Hibridização}

O objetivo principal, no melhoramento por hibridação, é aumentar a variabilidade genética, procurando introduzir característica de importância encontrada em acessos da mesma espécie ou de espécie diferente (BESPALHOK et al., 2007). A partir dos cruzamentos entre os indivíduos de interesse é gerada uma população com variabilidade genética, na qual realiza seleção visando à obtenção de linhagens que reúnam os fenótipos de interesse (SILVA, 2011).

Em soja, a hibridização é feita manualmente, utilizando pinça para emascular o botão floral que receberá o pólen (flor feminina). Os genitores femininos devem ser emasculados antes da antese, cortando o filete e retirando as anteras para impedir a autopolinização. Após esta operação, o pólen do genitor masculino é levado ao estigma da flor feminina. Cada flor é polinizada e identificada com os respectivos genitores feminino e masculino. Apesar de ser um procedimento simples, requer habilidade no manuseio, para evitar danos nas estruturas florais. Os instrumentos utilizados para a execução da hibridização são: uma pinça de ponta fina (de relógio), etiquetas para identificação e frascos para armazenar as flores (BORÉM et al., 1999; MUNIZ, 2007).

Fatores ambientais como período do dia, condições de umidade e temperatura devem ser levados em conta durante a emasculação e polinização das flores. As flores de soja mostram-se sensíveis as altas temperaturas e baixa umidade relativa do ar. Quando emasculadas nestas condições secam, rapidamente, não ocorrendo à fecundação (MUNIZ, 2007). Em virtude das 
condições ambientais serem variáveis, o melhorista deve variar o período de emasculação de acordo com cada condição. Quando os genótipos diferem em seu ciclo, deve-se utilizar o escalonamento das datas de semeaduras para que haja coincidência no florescimento (BONETTI, 1983). Sementes híbridas originarão as plantas $F_{1}$ que devem ser semeadas e cultivadas em condições controladas para favorecer maior produção de sementes $F_{2}$ em número suficiente para a descendência expressar recombinações para os caracteres favoráveis.

\subsubsection{Métodos de Condução de População Segregante de Soja}

Na condução de uma população segregante de plantas autógamas, o objetivo é selecionar no final do processo linhagens homozigotas com alelos favoráveis no maior número de locos. Para isso, existem vários métodos, como o genealógico, o da população, retrocruzamento e os modificados - entre estes, os mais utilizados são o descendente de uma única semente, conhecido como SSD (Single Seed Descent) e o método do "bulk" dentro de famílias (BRIM, 1966).

A escolha do método é importante, principalmente em função do tipo e da herança do caráter a ser melhorado. Métodos de condução de populações segregantes tem a finalidade de, através de sucessivas autofecundações, obter progênies homozigotas. Em geral, o melhorista conduz a população até $\mathrm{F}_{5}$ ou $\mathrm{F}_{6}$, quando a taxa de homozigotos é elevada, para fazer a seleção de plantas individuais originando progênies e realizar a seleção de linhagens superiores (CORDEIRO, 2008).

$\mathrm{O}$ método do "bulk" dentro de famílias derivadas de $\mathrm{F}_{2}$ associa os dois procedimentos padrões da condução das famílias segregantes em plantas autógamas, ou seja, o genealógico e o populacional "bulk". Com isso, espera-se reduzir o efeito de amostragem que é comum no 
método do "bulk" e o trabalho do genealógico. Por esse método, as plantas da geração $F_{2}$ são colhidas individualmente e as famílias $\mathrm{F}_{2: 3}$ são semeadas em linhas isoladas. Cada progênie é colhida individualmente e dará origem às famílias $\mathrm{F}_{2: 4}$, as quais são novamente semeadas em linha. $\mathrm{O}$ processo se repete até a geração $\mathrm{F}_{2: 6}$, quando então são selecionadas os melhores Indivíduos dentro de cada família para continuar a seleção. Por esse procedimento, toda a variação entre plantas presente na geração $F_{2}$ é mantida. Nesse caso, a seleção natural poderá acarretar perda por amostragem apenas dentro das famílias (ROSAL, 1999).

O método de "bulk" dentro de famílias $\mathrm{F}_{2}$ pode ser conduzido com algumas modificações; a principal delas é que, a partir da geração $\mathrm{F}_{2: 3}$, as famílias podem ser avaliadas em experimentos com repetição. Assim, a seleção nas gerações mais avançadas, como exemplo na $\mathrm{F}_{2: 6}$, será fundamentada no desempenho médio das famílias por duas a três gerações, dando maior segurança ao melhorista na decisão de quais famílias deverão ser mantidas (ROSAL, 1999).

\subsubsection{Seleção Precoce de Soja}

O teste de gerações precoces é usado em espécies alógamas ou autógamas na avaliação de potencial genético de individuo, progênie ou população, em gerações iniciais de endogamia. O principal objetivo é eliminar progênies ou populações pouco promissoras, que seguramente não terão potencial genético para originar linhagens superiores (CARVALHO, 2008).

O teste precoce objetiva aumentar o número de progênies com desempenho superior à média da população original (FEHR, 1987).

Os programas de melhoramento genético da soja estão voltados à obtenção de cultivares produtivas, estáveis e adaptadas às diversas regiões ambientais e aos vários sistemas de cultivo 
existentes no Brasil. A criação de cultivares, tem sido uma das tecnologias que mais tem contribuído para os aumentos de produtividade e estabilidade de produção, sem acrescentar custos adicionais ao agricultor (MIRANDA, 2005).

Para garantir produtividade e estabilidade os genótipos precisam apresentar porte e ciclo adequados, resistência ao acamamento, a pragas e doenças. Outras características especificas podem ser abrangidas pelos programas de melhoramento visando atender a necessidade do mercado como soja com alto teor de proteínas, com melhores características sensoriais para consumo humano e para processamento de alimentos (PÍPOLO et al., 2007).

A maioria dos caracteres de importância econômica, como a produção de grãos, é controlada por um grande número de genes, com baixa herdabilidade. Nesse sentido, para se obterem indivíduos superiores é necessário trabalhar com grandes populações de plantas. Segundo Ramalho et al. (1993) em populações segregantes de plantas autógamas, a probabilidade de manter o indivíduo com todos os alelos favoráveis é reduzida, com o avanço das gerações exigindo que se avalie um número crescente de famílias com o decorrer das gerações, o que, muitas vezes, inviabiliza o sucesso dos melhoristas. Para atenuar esse problema, a principal alternativa seria a seleção de plantas e/ou famílias já nas gerações iniciais, realizando a seleção precoce. No entanto, alguns trabalhos afirmam que a seleção precoce só é efetiva para caracteres de alta herdabilidade (ROSAL et al., 2000).

No método de seleção bulk dentro das famílias $F_{2}$, é possível que as mesmas sejam avaliadas em experimentos com repetições, já a partir da geração $F_{2}$ e $F_{2: 3}$, e a seleção precoce pode ser efetuada sem a utilização da seleção visual. Nessa condição, espera-se que a seleção precoce possa ser mais efetiva (ROSAL et al., 2000). O método de bulk dentro das famílias $\mathrm{F}_{2}$ 
permite, ainda, fazer seleção de maneira que sejam avançadas nas próximas gerações apenas as famílias que contenham as características desejadas incorporadas no seu genótipo.

\subsection{COMPONENTES GENÉTICOS}

A etapa intermediária que corresponde ao avanço das gerações de endogamia tem sido feita de forma relativamente rotineira, com a finalidade principal de desenvolver genótipos homozigotos, os quais, tendo fixado as combinações epistáticas favoráveis, aumentam a eficiência dos testes de desempenho agronômico (LOPES et al., 2002). Por outro lado linhagens homozigotas podem ser avaliadas com precisão experimental superior, pois dispõem de um maior número de sementes para locais, épocas de cultivo e anos agrícolas.

O avanço de gerações apresenta como desvantagens o longo período associado ao número de gerações e a demanda adicional de recursos humanos e financeiros. Uma das formas de contornar essa situação é a eficiente escolha dos genitores promissores logo nas gerações iniciais, de maneira que somente as respectivas populações sejam avançadas até originarem linhagens. Essa estratégia consegue eliminar ou reduzir, já nas gerações iniciais, problemas de incompatibilidade híbrida e diferenças na capacidade de combinação que levam à ocorrência de cruzamentos inferiores (ZORZETTO et al., 2008).

A possibilidade de se estimarem ganhos por determinada estratégia de seleção constitui-se em uma das mais importantes contribuições da genética quantitativa para o melhoramento de plantas, predizendo o sucesso do método de seleção adotado e determinando as estratégias mais eficazes. Várias são as estratégias utilizadas pelo melhorista para identificar os genótipos superiores numa população. Algumas levam em conta primeiramente, o desempenho da família e, 
posteriormente, a superioridade relativa dos indivíduos dentro da família (CRUZ; REGAZZI, 1994; REIS et al., 2004; BÁRBARO et al., 2007).

Em gerações avançadas de autofecundação, a seleção ao nível de família deve ser priorizada, facilitando a seleção de caracteres de baixa herdabilidade. Quando a seleção é praticada em determinado caráter, normalmente proporciona alterações em outros, devido a correlações genéticas existentes. Essa resposta correlacionada à seleção pode ser ou não de interesse para o melhorista. Seleção indireta é uma alternativa que pode aumentar a eficiência para caractere de baixa herdabilidade, quando esta se correlaciona com caráter de alta herdabilidade (BACKES et al., 2002).

A seleção baseada em um ou em poucos caracteres mostra-se ineficiente na obtenção de genótipo superior, mas com desempenho menos favorável em relação aos outros caracteres não considerados na seleção. Uma maneira passível de melhorar a eficiência é a seleção simultânea por um conjunto de caracteres de importância agronômica.

A obtenção de estimativas de parâmetros genéticos e fenotípicos, tais como herdabilidade, correlações genéticas e fenotípicas e ganhos esperados com seleção, têm importância em programas de melhoramento genético, pois possibilitam a tomada de decisões relacionadas com a escolha do método mais apropriado para seleção em etapas iniciais e avançadas de um programa e também o peso que deve ser atribuído a cada caráter, separadamente ou em conjunto (ROSSMANN, 2001).

Com os índices de seleção, obtêm-se um valor numérico que funciona como caráter adicional, teórico, resultante da combinação de determinados caracteres escolhidos pelo pesquisador, sobre os quais se deseja praticar a seleção simultânea. De modo geral, o ganho sobre o caráter é reduzido, no entanto essa redução é compensada por uma melhor distribuição dos 
ganhos favoráveis nos demais caracteres. Diferentes índices referem-se a alternativas de seleção e de ganhos. Eles identificam de maneira rápida e eficiente, as progênies que podem ser mais adequadas para os propósitos do melhorista (CRUZ; REGAZZI, 1994; BÁRBARO et al., 2007).

$\mathrm{Na}$ literatura, existem poucas informações sobre o comportamento de populações de soja nas gerações iniciais, isso ocorre pela dificuldade de realização dos cruzamentos, e pela quantidade de sementes das plantas $F_{1}$ serem limitadas, além do trabalho despendido com as avaliações (ZORZETTO et al., 2008). Os testes das gerações iniciais, $F_{1}, F_{2}, F_{3}$, podem ser feitos em ambientes diversos, possibilitando a estimação da capacidade de combinação e efeitos sobre a expressão fenotípica dos caracteres associados a parâmetros genéticos de seleção (ROCHA; VELLO, 1999).

Assim, com o auxílio desses parâmetros genéticos, é possível identificar genótipos superiores e selecionar os melhores genitores para futuras hibridações. Com a estimativa de parâmetros genéticos torna-se possível conhecer a estrutura genética dos indivíduos, essencial para seleção dos genótipos superiores. Além disso, é possível escolher qual o melhor método de melhoramento para cada caso (VILELA, 2008).

\subsubsection{Herdabilidade}

A herdabilidade de um caráter métrico é uma de suas mais importantes propriedades, pois expressa o grau de correspondência entre o valor fenotípico e o genotípico, faz parte da maioria das expressões empregadas no melhoramento genético, principalmente na predição de ganhos genéticos decorrentes de seleção. As estimativas de herdabilidade entre caracteres agronômicos 
são de extrema utilidade nos processos de seleção, em programas de melhoramento de qualquer espécie. (JOHNSON; BERNARD, 1967; FALCONER, 1987).

A estimativa de herdabilidade refere-se a uma característica de uma população e é específica para o ambiente no qual os genótipos foram estudados. Adicionalmente, podem-se estimar herdabilidade diferentes para serem usadas em cálculos de predição, variando a unidade de seleção (OLIVEIRA et al., 2000).

O coeficiente de herdabilidade, como expressão quantitativa, reflete a importância da herança e do ambiente na expressão de caracteres; quanto maior, maior será o sucesso de uma seleção para um dado caráter, resultando numa relação positiva entre alta herdabilidade e eficácia seletiva. $\mathrm{O}$ coeficiente de herdabilidade pode variar de 0 a 1; no caso em que for igual à unidade, o fenótipo é completamente determinado pelo genótipo, não tendo influência do ambiente sobre a manifestação do caráter. Um coeficiente igual à zero sugere que a variabilidade do caráter não tem origem genética. Valores maiores que 0,5 representam alto coeficiente de herdabilidade; valores compreendidos entre 0,2 e 0,5 coeficiente de herdabilidade médios e menores que 0,2, coeficiente de herdabilidade baixos (ALLARD, 1974; SILVEIRA et al., 2006).

Muitos caracteres de importância agronômica apresentam baixas herdabilidades ou são de difícil medição ou identificação, podendo a eficiência de sua seleção ser aumentada pelo uso de uma característica auxiliar correlacionada com a característica principal. A seleção de uma característica de baixa herdabilidade pode ser efetiva quando se utilizam outros caracteres, de maiores herdabilidades, apresentando alta correlação com a característica de interesse (OLIVEIRA et al., 2000).

A estimativa de herdabilidade para caracteres, economicamente importantes, é necessária na escolha de estratégia de melhoramento genético, permitindo definir o momento em que a 
seleção será mais eficiente e qual a intensidade a ser aplicada (MUNIZ et al., 2002). A herdabilidade varia de acordo com as características agronômicas e os fatores que afetam essas estimativas são: o método utilizado para estimar o valor da herdabilidade, a diversidade na população, o nível de endogamia da população, o tamanho da amostra avaliada, o número e tipo de ambientes, a unidade experimental e a precisão na condução do experimento e da coleta de dados (BORÉM; MIRANDA, 2009).

\subsubsection{Correlação}

A correlação destaca-se como uma medida importante para o estabelecimento de estratégias de melhoramento genético eficientes, por indicar a influencia que um caráter pode ter sobre outro. Esse parâmetro tenta explicar a variação de duas variáveis de forma conjunta, ou seja, medindo o grau de associação de duas variáveis. Quando uma variável está correlacionada com outra, a variação de uma é acompanhada com a variação da outra (RAMALHO et al., 2004).

Os coeficientes de correlação (r) podem ser classificados em função da magnitude dos seus

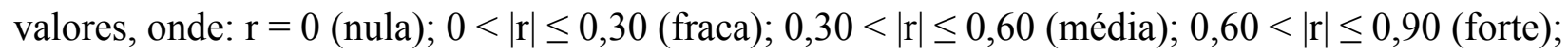
$0,90<|\mathrm{r}| \leq 1$ (fortíssima) e $|\mathrm{r}|=1$ (perfeita) (CARVALHO et al., 2004).

Com a correlação entre caracteres é possível fazer seleção indireta para um caráter desejado. Muitas vezes pode-se obter um progresso mais rápido do que na seleção direta. Entretanto, quando duas características são correlacionadas positivamente e com alto grau de associação, sendo uma delas indesejável, o melhorista encontra dificuldades (FALCONER, 1981). Isso também ocorre quando as duas características são desejáveis, mas apresentam correlações negativas com alto valor. 


\section{REFERÊNCIAS}

AGROESTE. Grupos de maturação, soja. 2014. Disponível em: <http://www.agroeste.com.br/intactarr2pro/beneficios_mostra.php?tipo=maturacao>. Acesso: 22 de outubro 2015.

AGROLINK. Nova variedade de soja chega ao mercado mineiro. 2012. Disponível: <http://www.agrolink.com.br/noticias/nova-variedade-de-soja-chega-ao-mercadomineiro_144148 .html>. Acesso: 30 de outubro 2015.

ALLARD, R. W. Princípios do melhoramento genético das plantas. Rio de Janeiro: Usaid, Edgard Blucher, 1974. 381p.

ALMEIDA, L. A.; KIIHL, R. A. S.; MIRANDA, M. A. C.; CAMPELO, G. J. A. 1999. Melhoramento da soja para regiões de baixas latitudes: In Recursos genéticos e melhoramento de plantas para o nordeste brasileiro. Disponível: http://www.cpatsa.embrapa.br/catalogo/livrorg/sojamelhoramento.pdf

ALMEIDA, R. D. Divergência genética entre cultivares de soja e correlações entre suas características, sob condições de várzea irrigada, no sul do Estado do Tocantins. Gurupi: Universidade Federal do Tocantins, 2008. 59 p. Dissertação Mestrado. 
AMARAL, V. M. G. A importância da soja como alimento funcional para qualidade de vida e saúde. Campinas: Universidade Estadual de Campinas, 2006. 86 p. Dissertação Mestrado.

BACKES, R. L.; REIS, M. S.; SEDIYAMA, T.; CRUZ, C. D.; TEIXEIRA, R. C. Estimativas de parâmetros genéticos em populações F5 e F6 de soja. Revista Ceres, n. 49, p. 201-216, 2002.

BÁRBARO, I. M.; CRUZ CENTURION, M. A. P.; DI MAURO, A. O.; UNÊDA-TREVISOLI, S. H.; COSTA, M. M. Comparação de estratégias de seleção no melhoramento de populações F5 $_{5}$ de soja. Revista Ceres, v. 54, n. 313, p. 250-261, 2007.

BASTIDAS, A. M.; SETIYONO, T. D.; DOBERMANN, A.; CASSMAN, K. G.; ELMORE, R.W.; GRAEF, G. L.; SPECHT, J. E. Soybean sowing date: the vegetative, reproductive, and agronomic impacts. Crop Science, v. 48, p.727-740, 2008.

BAYSAL, T.; DEMIRDÖVEN, A. Lipoxygenase in fruits and vegetables: A review. Enzyme and Microbial Technology, v. 40, p. 491-496, 2007.

BELLAVER, C.; COTREFAL, G.; GRECCO, M. Soja integral: processamento e uso. Alimento Animal, v.7, p. 28-30, 2002.

BENICASA, M. M. P. Análise de Crescimento de Plantas (noções básicas). Jaboticabal. FUNEP. 2004. 42 p. 
BESPALHOK, J. C., GUERRA, E. P., E OLIVEIRA, R. Melhoramento de Plantas. 2007. Acesso: 10 de março de 2013. Disponível em:<http://www.bespa.agrarias.ufpr.br/ paginas/livro/capitulo\%207.pdf>.

BEHRENS, J. H.; SILVA, M. A. A. P. Atitude do consumidor em relação à soja e produtos derivados. Ciência e Tecnologia de Alimentos, v. 24, p. 431-439, 2004.

BONETTI, L. P. Cultivares e seu melhoramento genético. In: FUNDAÇÃO CARGILL. Soja genética e melhoramento, v. 2, p. 741-800, 1983.

BONETTI, L. P. Distribuição da soja no mundo: origem, história e distribuição. In : MIYASAKA, S.; MEDINA, J.C. (Ed.). A soja no Brasil. Campinas: ITAL, p. 1-6, 1981.

BORÉM, A.; ALMEIDA, L. A.; KIIHL, R. A. S. Hibridização em soja. In: BORÉM, A. Hibridização artificial de plantas. Viçosa: UFV, 1999, p. 443-462.

BORÉM, A.; MIRANDA, G. V. Melhoramento de plantas. 5aed. Viçosa: Ed. Viçosa, 2009. 529 p.

BRIM, C. A. A modified pedigree method of selection in soybeans. Crop Science, v. 6, n. 220, 1966. 
CAMPELO, G. J.; KIIHL, R. A. S., ALMEIDA, L. A. Soja: Desenvolvimento para regiões de baixas latitudes. Teresina: Embrapa Meio-Norte, p. 36, 1998.

CARPENTIERI-PÍPOLO, V.; ALMEIDA, L. A.; KIIH, R. A. S. Inheritance of a long juvenile period under short-day conditions in soybean. Genetics and Molecular Biology, v. 25, p. 463469, 2002.

CARRÃO-PANIZZI, M. C. Melhoramento genético para obtenção de cultivares de soja mais adequados ao consumo humano. Revista Brasileira de Nutrição Clínica, v. 15, p. 330-340, 2001.

CARRÃO-PANIZZI, M. C.; SILVA, J. B. Soja na alimentação humana: qualidade na produção de grãos com valor agregado. In: Congreso De La Soja Del Mercosur, 5., 2011. Resumos. Rosário: Asociacións de la Cadena de la Soja Argentina, p. 1-3, 2011.

CARVALHO, F. I. F.; LORENCETTI, C.; BENIN, G. Estimativas e implicações da correlação no melhoramento vegetal. Pelotas: Ed. Universitária da UFPel, 2004. 142 p.

CARVALHO, A. D. F. Avaliação da eficiência do teste precoce no melhoramento genético de soja. Escola Superior de Agricultura Luiz de Queiroz, 2008. 102 p. Tese Doutorado.

CHEN, P.; BUSS, G. R. Breeding soybean for the soyfoods market: specific traits and strategies for selection. In: PROCEEDINS. III World Soybean Research Conference, IV 
International Soybean Processing and utilization and III Congresso Mundial de Soja. Foz do Iguaçu, Embrapa Soja, p. 830 - 835, 2004.

CISOJA-Centro De Inteligência da Soja. Sobre soja, Histórico, 2009. Disponível em: <http://www.cisoja.com.br>. Acesso em: 27 outubro 2015.

CONAB - Companhia Nacional de Abastecimento. Acompanhamento da safra brasileira: grãos safra 2014/2015: nono levantamento: junho de 2015.

CORDEIRO, A. C. C. Métodos de Melhoramento Genético de Arroz Irrigado. Boa Vista: Embrapa, 2008. 65 p.

CRANCIANINOV, W. S; FREITAS, A. M; SANTANA, A. C; MANDARINO, J. M. G; CARRÃO-PANIZZI, M. C. 2005. Composição química de soja verde para consumo como hortaliça. In: SIMPÓSIO LATINO AMERICANO DE CIÊNCIA DE ALIMENTOS, 6. Resumos. Campinas: Unicamp/FEA: SBCTA.

CRUZ, T. V. Crescimento e produtividade de cultivares de soja em diferentes épocas de semeadura no Oeste da Bahia. Cruz das Almas: Universidade Federal do Recôncavo da Bahia, 2007. 99 p. Dissertação Mestrado.

CRUZ, C. D. E; REGAZZI, A. J. Modelos biométricos aplicados ao melhoramento genético. Viçosa, UFV, 1994. 390 p. 
CRUZ, C. D.; REGAZZI, A. J. Modelos biométricos aplicados ao melhoramento genético. 2 ed. rev. Viçosa: Ed. UFV, 1997. 390 p.

DUFFY, C.; PEREZ, K.; PARTRIDGE, A. Implications of phytoestrogen intake for breast cancer. CA Cancer J Clin., v. 57, p. 260-277, 2007.

EMBRAPA. Tecnologia de produção de soja: região central do Brasil 2004, 2003. 237 p.

EMBRAPA. Catálago de produtos e serviços. BRSMG 800A, BRSMG 790A. 2009.

Disponível: <http://www.catalogosnt.cnptia.embrapa.br/catalogo20/catalogo_de_produtos_e_ servicos/arvore/CONT000h0cspof202wx7ha05ix163ajwr29i.html>. Acesso: 30 de outubro 2015.

EMBRAPA. Evolução e perspectivas de desempenho econômico associadas com a produção de soja nos contextos mundial e brasileiro. Documentos 319. 2011.

EMBRAPA - Empresa Brasileira de Pesquisa Agropecuária - Soja. Soja: Diferentes usos grãos, Londrina, Paraná. 2013. Disponível em: <https://www.embrapa.br/soja/cultivos/soja1/soja-naalimentacao> Acesso em 03 de novembro de 2015.

FALCONER, D. S. Introdução à genética quantitativa. Viçosa MG: UFV, 1981. 279 p. 
FALCONER, D. S. Introdução à genética quantitativa. Tradução de Silva, M. A. e Silva, J. C. Viçosa: Imprensa Universitária, 1987. 279 p.

FARIA, A. P.; FONSECA JÚNIOR, N. S. F.; DESTRO, D.; FARIA, R. T. Ganho genético na cultura da soja. Genetic gain in soybean crop, Semina: Ciencias Agrárias, v. 28, n. 1, p. 71-78, 2007.

FELIX, M. A.; CANNIATTI BRAZACA, S. G.; MACHADO, F. M. V. F. Análise sensorial dos grãos de soja (Glycine max (L.) Merril) tostados por diferentes tratamentos. Ciência e Tecnologia de Alimentos. v. 31, n. 1, p. 56-64, 2011.

FEHR, W. R. Principles of cultivar development: Theory and Technique. New York (USA): Mc-Graw Hill, 536 p.1987.

FIELTZ, M. R., RANGEL, M. A. S. Efeito da deficiência hídrica e do fotoperíodo no rendimento de grãos da soja semeada na região de Dourados, MS. Dourados, Embrapa Agropecuária Oeste, 2004. 5 p. Comunicado Técnico, 89.

GALLIARD, T.; CHAN, H. W. S. Lipoxygenases in the biochemistry of plants, P.K. New York: Academic, v. 4, 1980.

HAMAWAKI, O. T.; SAGATA, E.; HAMAWAKI, R. L.; MARQUES, M. C.; HAMAWAKI, C. D. L.; CORREIA, W. R. Desempenho de linhagens de soja de ciclo semiprecoce/médio e 
semitardio/tardio nas regiões do Triângulo Mineiro e Sul de Goiás. Bioscience Journal, v. 21, n. 3, p. 7-17, 2005.

HIRAOKA, N. K. A. Importância do uso da soja na alimentação. 2008. Disponível em: <http://www.diaadiaeducacao.pr.gov.br/portals/pde/arquivos/2520-6.pdf >. Acesso em: 02 de novembro de 2015.

JOHNSON, H. W.; BERNARD, R. L. Soybean, genetics and breeding. In: Norman, A.G. (ed.). The soybean genetics, breeding, physiology, nutrition and management. New York: Academic Press, 1967. p. 1-73.

KIIHL, R. A. S.; ALMEIDA, L. A. A. O futuro do melhoramento genético como agregador de tecnologia via semente. In: CONGRESSO DE TECNOLOGIA E COMPETITIVIDADE DA SOJANO MERCADO GLOBAL, 1., 2000, Cuiabá. Anais. Cuiabá: 2000. p. 45-47.

KITAMURA, K.; DAVIES, C.S.; KAIZUMA, N. Genetic analysis of a null-allele for lipoxygenase-3 in soybean seeds. Crop Science, v. 23, n.5, p. 924-927, 1983.

LIMA, W. F.; PÍPOLO, A. E.; MOREIRA, J. U. V.; CARVALHO, C. G. P.; PRETE, C. E. C.; ARIAS, C. A. A.; OLIVEIRA, M. F. DE; SOUZA, G. E. D.; e TOLEDO, J. F. F. Interação genótipo/ambiente de soja convencional e transgênica resistente a glifosato, no Estado do Paraná. Pesquisa Agropecuária Brasileira, v. 43, n. 6, p. 729-736, 2008. 
LOPES, A. C.; PANDINI, F.; ROCHA, M. M.; TSUTSUMI, Y. Variabilidade e correlações entre caracteres em cruzamentos de soja. Scientia Agrícola, v.59, n.2, p. 341-348, 2002.

MACHADO, C. F. Procedimentos para a escolha de genitores de feijão. Lavras: Universidade Federal de Lavras, 1999. 118 p. Dissertação Mestrado.

MARTINS, C. A. O.; SEDIYAMA, C. S; MOREIRA, M. A.; REIS, M. S.; ROCHA, V. S.; OLIVEIRA, M. G. A. Efeito da eliminação genética das lipoxigenases sobre as características agronômicas da soja. Pesquisa Agropecuária Brasileira, v. 37, n.10, p. 1389-1398, 2002.

MAGAlHãeS, A. C. N. Análise quantitativa do crescimento. In: FERRI, M. G. (Coord.). Fisiologia vegetal 1. São Paulo: EPU. Ed. da Universidade de São Paulo, 1979. v. 1, cap. 8, p. $331-350$.

MIRANDA, Z. F. S. Base genética de cultivares de soja no Brasil. Londrina: Universidade Estadual de Londrina, 2005. 80 p. Tese Doutorado.

MONTEIRO, M. R. P.; COSTA. N. M. B.; OLIVEIRA, M. G. A.; PIRES, C. V.; MOREIRA, M. A. Protein quality of soy lines lacking Kunitz's Trypsin Inhibitor and Lipoxygenase isozymes. Review of Nutrition, v. 17, n. 2, p. 195-205, 2004.

MUNIZ, F. R. S.; DI MAURO, A. O.; UNÊDA-TREVISOLI, S. H.; OLIVEIRA, J. A.;

BÁRBARO, I. M.; ARRIEL, N. H. C.; COSTA, M. M. Parâmetros genéticos e fenotípicos em 
populações segregantes de soja. Revista bras. de Oleaginosas e Fibrosas, v. 6, n. 3, p. 615-622, 2002.

MUNIZ, F. R. S. Análise da variabilidade genética em populações segregantes de soja. Jaboticabal: Universidade Estadual Paulista, 2007. 86 p. Tese Doutorado.

OETTERER, M.; REGITANO-D’ARCE, M. A. B.; SPOTO, M. H. Fundamentos de ciência e tecnologia de alimentos. Editora Manole, Barueri/SP, p. 384-396, 2006.

OLIVEIRA, A. C. B.; VIANA, J. M. S.; CRUZ, C. D.; SEDIYAMA, C. S.. Herdabilidade e correlações em plantas $F_{2}$ de soja cultivadas em diferentes condições ambientais. Acta Scientiarum, n. 22, p. 889-893, 2000.

OliveirA, M. A.; CARRÃO-PANIZZI, M. C.; MANDARINO, J. M. G.; LEITE, R. S. Produção de brotos de soja utilizando a cultivar BRS 216: caracterização físico-química e teste de aceitabilidade. Brazilian Journal of Food Technology, v. 16, n. 1, 2013.

PEIXOTO, C. P.; PEIXOTO, M. F. P. Dinâmica do crescimento vegetal (Princípios Básicos). Cruz das Almas, 2004.

PEIXOTO,C. P.; CRUZ, T. V.; PEIXOTO, M. F. S. P. Análise quantitativa do crescimento de plantas: Conceitos e Prática. Enciclopédia Biosfera, Centro Científico Conhecer - Goiânia, v.7, n.13, 2011. 
PENARIOL, A. Soja: cultivares no lugar certo. Informações agronômicas $\mathrm{n}^{\circ}$ 90, 2000. Disponível em: <http://www.ipni.net/PUBLICATION/IA-BRASIL.NSF/0/3D7A D150106A80E683257AA30069BE0F/\$FILE/pages13-14-90.pdf>. Acesso: 22 de outubro 2015.

PEREIRA, A. R.; MACHADO, E. C. Análise quantitativa do crescimento de vegetais. Campinas. Instituto Agronômico. Campinas, 1987. 33 p.

PÍPOLO, A. E.; ARIAS, C. A. A.; CARNEIRO, G. E. S.; TOLEDO, J. F. F.; OLIVEIRA, M. F.; PANIZZI, M. C. C.; KASTER, M.; ALDELNOOR, R. L.; MOREIRA, J. U. V. Desenvolvimento de geomoplasma e cultivares de soja. Circular Técnica, n. 52, 10 p. Londrina: EMBRAPA-Soja, 2007. ISSN 1516-7860.

RAMALHO, M. A. P.; SANTOS, J. B.; ZIMMERMANN, M. J. O. Genética quantitativa em plantas autógamas: aplicações no melhoramento do feijoeiro. Goiânia: UFG, 1993. 271 p.

RAMALHO, M. A. P.; SANTOS, J. B.; PINTO, C. A. B. P. Genética na agropecuária. 3 ed. rev., Lavras: UFLA, 2004. 472 p.

REIS, G. G.; MULLER, M. W. Análise de crescimento de plantas - mensuração do crescimento. Belém, CPATU, 1978. 35p. 
REIS, E. F.; REIS, M. S.; CRUZ, C. D.; SEDIYAMA, T. Comparação de procedimentos de seleção para produção de grãos em populações de soja. Ciência Rural, n. 34, p. 685-692, 2004.

REZENDE, P. M.; CARVALHO, E. A. Avaliação de cultivares de soja [Glycine max (L.) Merrill para o sul de Minas Gerais. Ciência e Agrotecnologia, v. 31, n. 6, p. 1616-1623, 2007.

RIGO, A. A. Obtenção e caracterização de farinhas de soja das cultivares BRS 267, BRS

257 e VMAX. Erechim: Universidade Regional Integrada do Alto Uruguai e das Missões, 2015. 89 p. Dissertação Mestrado.

ROBINSON, D. S.; WU, Z.; DOMONEYB, C.; CASEY, R. Lipoxygenases and the quality of foods. Food Chemistry, v. 54, p. 33-43, 1995.

ROCHA, M. M.; VELLO, N. A. Interação genótipos e locais para rendimento de grãos de linhagens de soja com diferentes ciclos de maturação. Bragantia, v.58, p. 69-81, 1999.

RODRIGUES, O.; DIDONET, A. D.; LHAMBY, J. C. B.; BERTAGNOLLI, P.F.; LUZ, J. S. Resposta quantitativa do florescimento da soja à temperatura e ao fotoperíodo. Pesquisa Agropecuária Brasileira, v. 36, p. 431-437, 2001.

ROSAL, C. J. S. Seleção precoce para a produtividade no feijoeiro (Phaseolus vulgaris L.). Lavras: Universidade Federal de Lavras, 1999. 50 p. Dissertação Mestrado. 
ROSAl C. J. S., RAMAlho M. A. P., GONÇAlVES F. M. A., ABREU, A. F. B. Seleção precoce para a produtividade de grãos no feijoeiro. Bragantia, n. 59, p.189-195, 2000.

ROSSMANN, H. Estimativas de parâmetros genéticos e fenotípicos de uma população de soja avaliada em quatro anos. Piracicaba: Escola Superior de Agricultura "Luiz de Queiroz”/USP, 2001. Dissertação Mestrado.

SANTOS, V. S. Seleção de pré-cultivares de soja baseada em índices. Piracicaba: Universidade de São Paulo, 2005. 104 p. Tese Doutorado.

SANTOS, E. R.; BARROS, H. B.; CAPONE, A.; FERRAZ, E. C.; SANTOS, A. F.; FIDELIS, R. R. Divergência entre genótipos de soja, cultivados em várzea irrigada. Revista Ceres, v. 58, n.6, p. 755-764, 2011.

SANTOS, E. R. Divergência genética entre genótipos de soja com base em características fisiológicas e morfoagronômicas. Gurupi: Universidade Federal do Tocantins, 2011. 105 p. Dissertação Mestrado.

SEDIYAMA, T. Tecnologia de produção da soja. Editora Mecenas LTDA . 2009. Londrina, $314 \mathrm{p}$. 
SEIBEL, N. F.; ALVES, F. P.; OLIVEIRA, M. A.; LEITE, R. S. Brazilian Soybean Varieties for Human Use. Intech open Science, 2013. Disponível: < http://cdn.intechopen.com/pdfswm/39505.pdf >. Acesso: 08 de novembro 2015.

SETIYONO, T. D.; WEISS, A.; SPECHT, J.; BASTIDAS, A. M.; CASSMAN, K. G.; DOBERMANN, A. Understanding and modeling the effect of temperature and day length on soybean phenology under high-yield conditions. Field Crops Research, v. 100, p. 257-271, 2007.

SILVA, M. D.; OLIVEIRA, M. G. A.; LANNA, A. C.; PIRES, C. V.; PIOVESAN, N. D.; JOSE, I. C.; BATISTA R. B.; BARROS, E. G.; MOREIRA, M. A. Caracterização da via das lipoxigenases em plantas de soja resistentes e susceptíveis a Diaporte phaseolorum f.sp. meridionalis, agente causal do cancro-da-haste. Revista Brasileira de Fisiologia Vegetal, v. 13, n. 3, p. 316-328, 2001.

SILVA, V. Características fisiológicas de cultivares de mamoneira (Ricinus communis L.) no Recôncavo Baiano. Cruz das Almas: Universidade Federal do Recôncavo da Bahia, 2008. 73 p. Dissertação Mestrado.

SILVA, J. B.; CARRÃO-PANIZZI, M. C.; PRUDÊNCIO, S. H. Chemical and physical composition of grain type and food type soybean for food processing. Pesquisa Agropecuária Brasileira, v. 44, n.7, p. 777-784, 2009. 
SILVA, V. M. P. Melhoramento Genético do Porte do Feijoeiro. Viçosa: Universidade Federal de Viçosa, 2011. 60 p. Tese Doutorado.

SILVEIRA, G. D.; MAURO, A. O. D.; CENTURION, M. A. P. C. Seleção de genótipos de soja para a região de Jaboticabal, SP, Ano agrícola 2003-2004. Científica, v. 34, n. 1, p. 92-98, 2006.

SMALING, E. M. A.; ROSCOE R. C.; LESSCHEN, J. P.; BOUWMANE, A. F.; COMUNELLO, E. From forest to waste: Assessment of the Brazilian soybean chain, using nitrogen as a marker. Agriculture, Ecosystems and Environment, v. 128, p. 185-197, 2008.

SOUZA, L. H. B. Crescimento e desenvolvimento de girassol em diferentes épocas de semeadura no Recôncavo da Bahia. Cruz das Almas: Universidade Federal do Recôncavo da Bahia, 2010. 88 p. Dissertação Mestrado.

ST MARTIN, S. K.; XIE, F.; ZHANG, H.; ZHANG, W.; SONG, X. Epistasis for quantitative traits in crosses between soybean lines from China and the United States. Crop Science, v. 49, p. 20-28, 2009.

SPEHAR, C. R. Impact of strategic genes in soybean on agricultural development in the Brazilian tropical savannahs. Field Crops Research, v. 41, p.141-146, 1995. 
SPEHAR, C. R.; MONTEIRO, P. M. F. O.; ZUFFO, N. L. Melhoramento genético da soja na região Centro-Oeste. In: ARANTES, N.A.; SOUSA, P.I. de M. de (Ed.). Cultura da soja nos cerrados. Piracicaba : Potafos, 1993. p. 229-253.

VASCONCELOS, I. M.; MAIA, A. A. B.; SIEBRA, E. A.; OLIVEIRA, J. T. A.; CARVALHO, A. F. F. U.; MELO, V. M. M.; CARLINI, C. R.; CASTELAR, L. I. M. Nutritional study of two Brasilian soybean (Glycine max) cultivars differing in the contents of antinutritional and toxic proteins. Journal of Nutrition and Biochemistry, v. 12, n.1, p. 55-62, 2001.

VILELA, M. S. Estimativas de parâmetros genéticos para caracteres de cenoura em sistemas de cultivo agroecológico. Brasília: Universidade de Brasília, 2008. 68 p. Dissertação Mestrado.

ZORZETTO, M. M.; MOTTA, F. C.; MORAIS, L. K.; KIIHL, T. A. M. Análise dialélica da capacidade combinatória em soja. Revista Biociências, v. 14, n. 2, 2008.

YOKOMIZO, G. K.; DUARTE, J. B.; VELLO, N. A. Correlações fenotípicas entre tamanho de grãos e outros caracteres em topocruzamentos de soja tipo alimento com tipo grão. Pesquisa Agropecuária Brasileira. v. 35, n. 11, p. 2235-2241, 2000. 
CAPítulo 1. CARACTERísticas AGRonômicas DE SOJA, SEM LIPOXIGENASES, INTRODUZIDAS EM BAIXAS LATITUDES DO ESTADO DO TOCANTINS

CHAPTER 1. AGRONOMIC CHARACTERISTICS OF FREE-LYPOXYGENASE SOYBEAN INTRODUCED IN LOW LATITUDES OF THE STATE OF TOCANTINS 


\section{RESUMO}

Objetivou-se com este trabalho avaliar os componentes fisiológicos e agronômicos de soja tipo alimento, introduzida no Estado do Tocantins, em comparação com soja tipo comum selecionada para as baixas latitudes. O experimento foi conduzido na Universidade Federal do Tocantins, localizado a $11^{\circ} 43^{\prime} \mathrm{S}$ e $49^{\circ} 04^{\prime} \mathrm{W}$. O desenho experimental foi de blocos ao acaso com quatro cultivares e quatro repetições. Os tratamentos foram BRSMG790A e BRS 257, do tipo alimento; A7002 e M 8585 do tipo comum de grão. Avaliaram-se: altura de plantas (AP), número de dias para o florescimento (NDF), número de dias para a maturação (NDM), número de dias do período reprodutivo (NDPR), número de vagens por planta (NVP), massa seca (MS), produção de grãos (PG), área foliar (AF) e taxas de crescimento: índice de área foliar (IAF), taxa de área foliar (TAF), taxa de assimilação líquida (TAL), taxa absoluta de crescimento (TAC) e taxa relativa de crescimento (TRC). As cultivares BRSMG 790A e BRS 257 apresentaram valores mais baixos de AP, AF, IAF, RAF, TAL, TCA e TCR refletido pelo florescimento e maturação, precoce que também influenciaram negativamente os componentes produtivos como NVP, MS e RG. Os cultivares do tipo alimento não apresentaram adaptação à produção comercial no Estado do Tocantins, mas podem ser empregados em hibridações com soja adaptada localmente, possuindo período juvenil longo, constituindo-se em fonte de variabilidade genética em programas de melhoramento de soja adaptadas às baixas latitudes.

Palavras-chave: Glycine max; índice de área foliar; taxa de assimilação líquida; taxa de crescimento relativo; razão de área foliar; massa seca 


\begin{abstract}
This study aimed at evaluating physiological and agronomic components of food type soybean introduced in the State of Tocantins, as compared to common type locally adapted cultivars. The experiment was conducted at the Federal University of Tocantins, located at $11^{\circ}$ $43^{\prime} \mathrm{S}$ and $49^{\circ} 04^{\prime} \mathrm{W}$. The experimental design was complete randomized block with four cultivars and four repetitions of food type BRSMG790A and BRS 257, and common type A7002 and M 8585. Evaluations were made on plant height (PH), number of days to flowering (NDF), number of days to maturity (NDM), number of days of the reproductive period (NDPR), number of pods per plant (NPP), dry matter (DM), grain yield (GY), leaf area (LA) and growth rates: leaf area index (LAI), leaf area ratio (LAR), net assimilation rate (NAR), absolute growth rate (AGR) and relative growth rate (RGR). The BRSMG 790A and BRS 257 had lower PH, LA, LAI, LAR, NAR, AGR and RGR, reflected by NDF and maturity, reducing NPP, DM and GY. These freelypoxigenase cultivars are not adapted to soybean commercial production at low latitudes of Tocantins but can be employed in hybridization with long-juvenile, locally adapted cultivars, being a source of genetic diversity in breeding programs.
\end{abstract}

Key words: Glycine max; leaf area index; net assimilation rate; relative growth rate; leaf area ratio; dry matter 


\subsection{INTRODUÇÃO}

Soja (Glycine max L.) foi introduzida e selecionada para a produção comercial nos principais países produtores como nos Estados Unidos da América e no Brasil onde é direcionada, principalmente, para produção de óleo e alimentação animal. No entanto, em países asiáticos como China, Coréia e Japão tem sido cultivada há milênios como importante fonte de proteínas e outros compostos como carboidratos, fibras, minerais, vitamina A, E, B1 e B2 para os humanos. A soja possui propriedades funcionais como as isoflavonas, além de ser rica em proteínas é também a única alternativa para as pessoas com intolerância à lactose (SILVA et al., 2012).

Os subprodutos da soja ganharam espaço considerável no mercado, por suas propriedades nutracêuticas, com numerosas alegações ligando seus efeitos à promoção da saúde. Contudo, estima-se que apenas $6 \%$ da soja produzida no Brasil seja destinada a produtos alimentares. Apesar das vantagens demonstradas pelo consumo da soja, muitos consumidores potenciais ainda evitam usá-la na dieta, principalmente devido à presença de odores e sabores indesejáveis proporcionados pelas enzimas lipoxigenase (SILVA et al., 2009).

Essa diferença sensorial faz da soja comum indesejável na preparação de alimentos como tofu e outros alimentos derivados. Visando melhorar o sabor da soja, programas de melhoramento genético vêm desenvolvendo cultivares de soja com características mais adequadas ao consumo humano a exemplo BRS 257, isenta das enzimas lipoxigenases e BRSMG 790A que apresenta sabor mais suave (CARRÃO-PANIZZI; SILVA, 2011). As cultivares do tipo alimento foram selecionados para maiores latitude do Brasil, as quais não apresentam juvenilidade longa. $\mathrm{O}$ 
periodo juvenil longo estende o período vegetativo e estão presentes em genótipos adaptados tropicais (SPEHAR et al., 2014).

A análise de crescimento baseia-se, fundamentalmente, no fato de que cerca de $90 \%$, em média, da matéria seca acumulada pelas plantas ao longo do seu desenvolvimento resulta da atividade fotossintética. A análise de crescimento permite avaliar o crescimento final da planta como um todo e a contribuição dos diferentes órgãos no desenvolvimento total (YUSUF et al., 1999). Apesar da complexidade, a análise de crescimento é um meio bastante preciso para avaliar e compreender os processos fisiológicos, quantificando as respostas das plantas às variações ambientais (MEHMET SINCIK et al., 2011). Além disso, tem sido útil no melhoramento genético das culturas por demostras quais apresentam maior eficiência fotossintética e rendimento (MORRISON et al., 1999).

Aplicações de análise de crescimento têm sido relatados para definir as fases de desenvolvimento da planta de diversas culturas como mamona (SANTOS et al., 2011c), feijãocaupi (SANTOS et al., 2011a, ANDRADE JÚNIOR et al., 2014 e FREITAS et al., 2014), tomate (MARTINAZZO et al., 2015) e soja (CRUZ et al., 2010).

A introdução de genótipo tem sido a forma mais utilizada, para avaliar a adaptação de uma cultura ao novo ambiente, enquanto a análise de crescimento permite estimar as causas das variações no desenvolvimento da planta. Ele tem sido essencial para compreender as diferenças estruturais e funcionais entre genótipos de mesma espécie, visando à seleção para a estabilidade de rendimento (SPEHAR et al., 2014).

O potencial de crescimento da soja em baixas latitudes do Brasil tem sido realizado por seleção de cultivares com fase vegetativa prolongada, incorporando alelos para período juvenil longo (SPEHAR et al., 2014). Esses alelos induzem a planta a crescer e a produzir em níveis 
comparáveis aos obtidos em regiões temperadas. As áreas agrícolas do Estado de Tocantins estão localizadas entre as latitudes $5-13^{\circ} \mathrm{S}$ e baixa altitude, onde a soja do tipo comum (destinada a produção de grão para produção de óleo e farelo) foi adaptada de forma competitiva. No entanto, o cultivo de soja com ausência de lipoxigenase (destinada à alimentação humana) nesta região ainda não foi realizado, justificando estudos para compreender as fases de crescimento e reprodução genotípicas.

Objetivou-se com este trabalho avaliar cultivares de soja do tipo de alimento, introduzidas no Estado do Tocantins com base na análise de crescimento e desempenho agronômico. Esperase que os resultados possam ser úteis para auxiliar programas de melhoramento de soja na obtenção de cultivares de soja, com ausência de lipoxigenase e com rendimentos competitivos para baixa latitude.

\subsection{MATERIAL E MÉTODOS}

O experimento foi conduzido, na Universidade Federal do Tocantins, Campus Universitário de Gurupi, Estado do Tocantins, localizada a $11^{\circ} 43^{\prime} \mathrm{S} 49^{\circ} 04^{\prime} \mathrm{W}$ e altitude de $280 \mathrm{~m}$, em Latossolo Vermelho Amarelo Distrófico na classificação de solos da FAO (IUSS Grupo de Trabalho WRB , 2015).

As análises químicas e físicas do solo foram realizadas no laboratório de solos do Departamento de Solos da Universidade Federal de Lavras e apresentaram as seguintes

características: $\mathrm{pH}=5,6 ; \mathrm{Al}+\mathrm{H}=2,6 \mathrm{cmol}_{\mathrm{c}} \mathrm{dm}^{-3} ; \mathrm{Ca}+\mathrm{Mg}=2,8 \mathrm{cmol}_{\mathrm{c}} \mathrm{dm}^{-3} ; \mathrm{K}=72 \mathrm{mg} \mathrm{dm}^{-3}$; $\mathrm{P}=3,7 \mathrm{mg} \mathrm{dm}^{-3} ; \mathrm{V}=53,5 \% ; \mathrm{SB}=3,0 \mathrm{cmol}_{\mathrm{c}} \mathrm{dm}^{-3} ; \mathrm{CTC}=5,6 \mathrm{cmol}_{\mathrm{c}} \mathrm{dm}^{-3}$; matéria orgânica: 2,2 dag $\mathrm{Kg}^{-1} ;$ areia $=71 \mathrm{dag} \mathrm{Kg}^{-1} ;$ silte $=5,0 \mathrm{dag} \mathrm{Kg}^{-1} ; \operatorname{argila}=24,0 \mathrm{dag} \mathrm{Kg}^{-1}$. 
O clima foi classificado como Aw, umido com déficit hídrico moderado (KOTTEK et al., 2006). Durante o crescimento da planta os dados climáticos foram coletados na estação meteorológica do Campus com distância de 50 m (Figura 1).

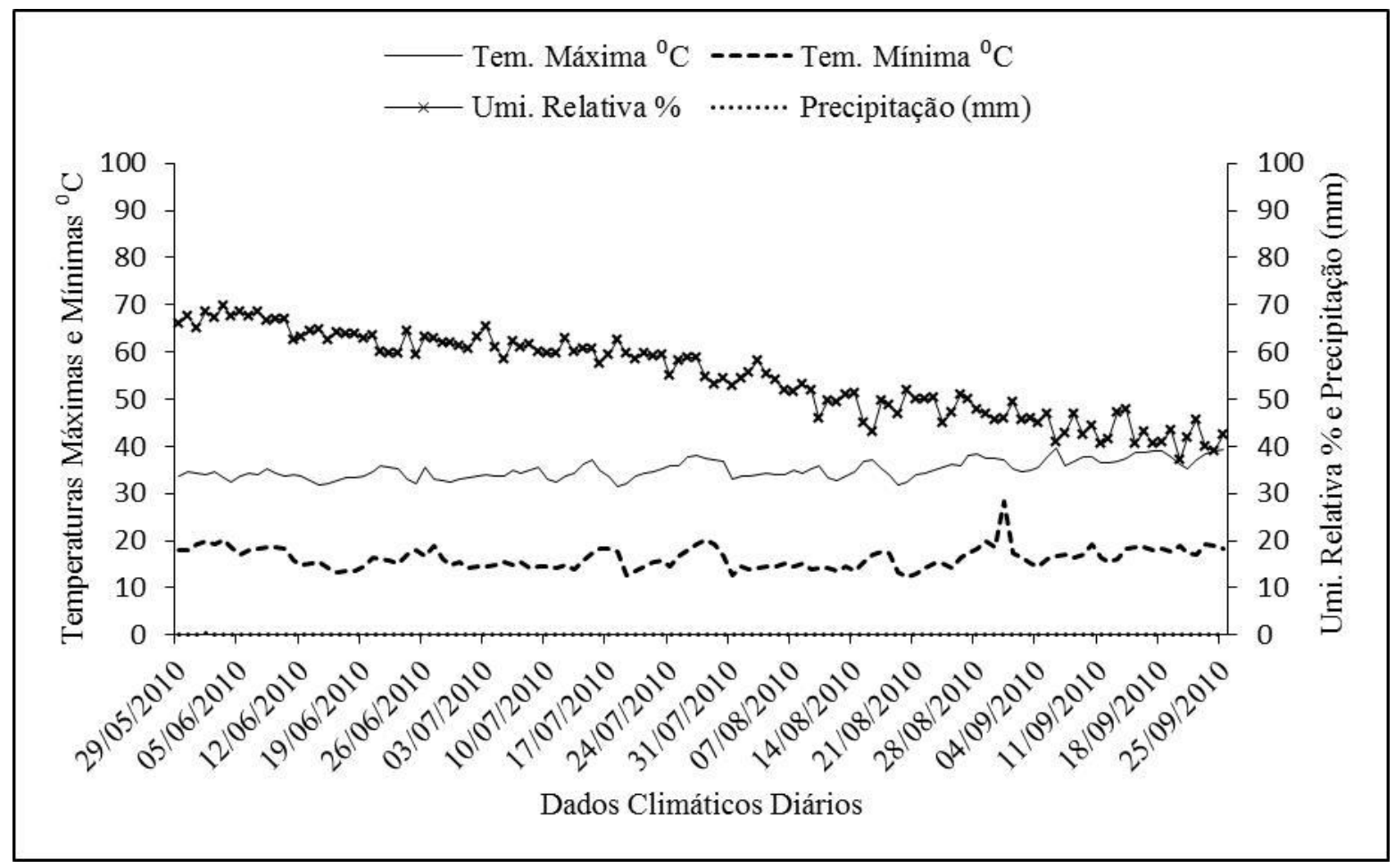

Figura 1. Valores médios diários de temperaturas máxima e mínima $\left({ }^{\circ} \mathrm{C}\right)$, total diário de precipitação pluvial $(\mathrm{mm})$ e valores médios diários da umidade relativa do ar (\%), ocorridas durante o período de 29 de maio a 25 de setembro de 2010, Gurupi, TO.

O experimento foi implantado em 29 de maio de 2010, sob sistema de plantio direto. As adubações de semeadura foram feitas baseando-se nos resultados da análise do solo, sendo aplicadas no sulco de semeadura correspondendo a $60 \mathrm{~kg}$ de $\mathrm{P}_{2} \mathrm{O}_{5} \mathrm{ha}^{-1}$, $60 \mathrm{~kg}$ de $\mathrm{K}_{2} \mathrm{O}$ ha ${ }^{-1}$, da formulação NPK 00-16-16, no momento da semeadura inoculou-se as sementes com estirpes de Bradyrhizobium japonicum. 
O delineamento experimental adotado foi o de blocos casualizados com quatro tratamentos e quatro repetições. Foram testados quatro tratamentos sendo: duas cultivares de soja tipo alimento: BRSMG 790A (apresenta sabor suave) e BRS 257 (triplo nulo para lipoxigenases) e duas cultivares de soja tipo comum: A7002 e M 8585 (destinadas a produção de óleo e farelo). As cultivares apresenta período m as seguintes características (Tabela 1).

Tabela 1. Cultivares de soja tipo alimento (BRSMG 790A e BRS 257) e tipo comum (A 7002 e M 8585) e suas respectivas caracteristicas: região indicada ao cultivo, maturação relativa e empresa responsável pelo lançamento.

\begin{tabular}{lccc}
\hline Cultivar & Região de cultivo & Maturação relativa & Empresa \\
\hline BRSMG 790A & MG, GO, DF e SP & 7.9 & Embrapa \\
BRS $257^{2}$ & RS, PR, SP & 6.4 & Embrapa \\
A 7002 & \\
M $8585^{3}$ & MT, MG, GO, DF, TO & 8.2 & Nidera \\
& MT, MG, GO, DF, TO & 8.5 & Monsanto
\end{tabular}

Fonte: Tecnologias de Produção de Soja - Região Central do Brasil 2009 e 2010.

${ }_{2}^{1}$ Apresenta sabor suave, destinada a alimentação humana.

${ }_{3}^{2}$ Triplo nula para lipoxigenase, destinada a alimentação humana

3 Apresenta período juvenil longo e presença de lipoxigenases, grãos destinados a produção de óleo e farelo.

A unidade experimental foi composta por cinco linhas de 6 metros de comprimento, espaçadas de 0,45 m entre linhas e 0,08 m entre plantas. Para análise de crescimento foi considerada como parcela útil a segunda fileira, que foi subdividida em dez subparcelas para amostragens periódicas das plantas. Para produtividade foi adotada como parcela útil a quanta fileira. 
$\mathrm{O}$ experimento foi mantida livre de ervas daninhas por capinas manuais e irrigado antes $\mathrm{VC}$ até R8 (FEHR et al., 1971). Adotou-se sistema de irrigação por aspersão, com turno de rega de 65 minutos com lâmina de água de $6 \mathrm{~mm}$, três vezes por semana, de forma a manter o solo com $70 \%$ da capacidade de campo.

As plantas para análise de crescimento foram coletadas aos 15, 25, 35, 45, 55, 65, 75, 85, 95 e 105 dias após a emergência (DAE), totalizando em dez amostragens, com intervalo de dez dias. Em cada avaliação foram coletadas cinco plantas por parcela.

As variáveis avaliadas para análise de crescimento foram: a) Altura de plantas (AP): medindo da base da planta até a extremidade apical (tufo foliar) da haste principal, com auxilio de uma trena graduada; b) massa seca (MS): As plantas coletadas tiveram a parte aérea dividida em: folhas, caules, flores e vagens e posteriormente secas em estufa de ventilação forcada a $70{ }^{\circ} \mathrm{C}$ até atingir massa constante. Em seguida foram pesadas em balança de precisão para obtenção de massa seca total; c) área foliar (AF): foi determinada a partir da massa seca de dez discos, posteriormente estimada com base na relação entre área foliar e massa foliar conforme descrito por Daughtry (1990); d) índice de área foliar (IAF): determinado pela relação entre a área foliar média das plantas e a superfície correspondente de terreno, $\mathrm{m}^{2} \mathrm{~m}^{-2}$; e) razão de área foliar (RAF): definida como sendo o quociente entre IAF e MS, em $\mathrm{m}^{2} \mathrm{~g}^{-1}$; f) taxa de assimilação líquida (TAL): determinada pela razão entre TCC e IAF, em $\mathrm{g} \mathrm{m}^{-2} \mathrm{dia}^{-1}$; g) taxa de crescimento absoluto (TCA); h) taxa de crescimento relativo (TCR): expressa em $\mathrm{g} \mathrm{g}^{-1} \mathrm{dia}^{-1}$ e calculada pelo quociente entre a taxa de crescimento da cultura e a MS. As medidas de crescimento da cultura e suas análises foram adaptadas de metodologias existentes (HOFFMANN; POORTER, 2002; PRICE; MUNNS, 2010). 
Para os dados referentes à análise de crescimento, foram grafadas curvas de modelos lineares ou polinomial quadrático, com base nas médias de cada coleta realizada, e a análise de regressão adotada foi a que melhor se ajustou aos dados e no maior valor do coeficiente de determinação $\left(\mathrm{R}^{2}\right)$. A utilização de equações de regressão não só corrige as oscilações normais, como permite avaliar a tendência do crescimento em função dos tratamentos (PRICE; MUNNS, 2010).

Quanto às características agronômicas foram avaliadas: a) florescimento (NDF): período que correspondeu ao número de dias decorridos entre a emergência das plântulas até $50 \%$ do florescimento das plantas da parcela; b) maturação (NDM), período que correspondeu ao número de dias decorridos desde a emergência das plântulas até a data em que $95 \%$ das vagens das plantas da parcela apresentaram-se maduras; c) número de dias do período reprodutivo (NDPR), período decorrido entre o início do florescimento até a maturação; d) número de vagens, por plantas (NVP), média obtida pela contagem direta de vagens de cinco plantas; e) rendimento de grãos (RG): determinado após a trilha das plantas e limpeza dos grãos com posterior correção da

umidade dos grãos para 13\%, convertendo-os em $\mathrm{Kg} \mathrm{ha}^{-1}$. Os dados foram submetidos à análise de variância, e ao teste de Tukey $(\mathrm{P} \leq 0,05)$ de probabilidade pelo teste $\mathrm{F}$ usando o programa estatístico SISVAR.

\subsection{RESULTADOS E DISCUSSÃO}

Altura de plantas ajustou-se a curvas quadráticas, com $\mathrm{R}^{2}$ entre de 0,97 e 0,98 (Tabela 2 e Figura 2A). Indiferentemente da cultivar verificou-se crescimento lento no período inicial de desenvolvimento das plantas até os 25 DAE. Após este período as cultivares A7002 e M 8585, 
sobressaíram significativamente as cultivares tipo alimento, seguido por fase de rápido crescimento até os 65 DAE (Figura 2A).

Tabela 2: Equações ajustadas para altura de plantas (AP), massa seca (MS), área foliar (AF), índice de área foliar (IAF), razão de área foliar (RAF), taxa de assimilação liquida (TAL), taxa de crescimento absoluto (TCA) e taxa de crescimento relativo (TCR) de para plantas de soja tipo alimento BRSMG 790A, BRS 257 e tipo comum A7002 e M 8585 cultivadas em Gurupi, TO, localizado a $11^{\circ} 43^{\prime}$ de latitude Sul

\begin{tabular}{|c|c|c|c|c|}
\hline Cultivares & $\mathrm{AP}(\mathrm{cm})$ & $\mathrm{R}^{2}$ & MS (g planta $\left.{ }^{-1}\right)$ & $\mathrm{R}^{2}$ \\
\hline BRSM790A & $y=-0,008 x^{2}+1,372 x-9,957$ & $0,97^{* *}$ & $y=4,4473 x-7,6086$ & 0,93 \\
\hline BRS257 & $y=-0,0075 x^{2}+1,072 x-1,482$ & $0,98^{* *}$ & $y=3,5128 x-5,3048$ & $0,97^{* *}$ \\
\hline A7002 & $y=-0,013 x^{2}+2,401 x-26,99$ & $0,98^{* *}$ & $y=4,2745 x-9,4902$ & $0,91^{* *}$ \\
\hline M8585 & $y=-0,0104 x^{2}+2,099 x-23,54$ & $0,98^{* *}$ & $Y=4,0444 x-8,364$ & $0,94^{* *}$ \\
\hline Cultivares & $\mathrm{AF}\left(\mathrm{cm}^{2}\right.$ planta $\left.^{-1}\right)$ & & IAF & \\
\hline BRSM790A & $y=-0,569 x^{2}+69,35 x-1069$ & $0,73^{*}$ & $y=-0,18 x^{2}+2,021 x-2,34$ & $0,73^{*}$ \\
\hline BRS257 & $y=-0,291 x^{2}+34,51 x-443,78$ & $0,86^{*}$ & $y=-0,092 x^{2}+1,003 x-0,88$ & $0,86^{*}$ \\
\hline A7002 & $y=-0,312 x^{2}+48,57 x-757,62$ & $0,82^{*}$ & $y=-0,099 x^{2}+1,443 x-1,66$ & $0,82^{*}$ \\
\hline M8585 & $y=-0,365 x^{2}+58,63 x-958,85$ & $0,83^{*}$ & $y=-0,116 x^{2}+1,745 x-2,14$ & $0,83^{*}$ \\
\hline Cultivares & $\operatorname{RAF}\left(\mathrm{cm}^{2} \mathrm{~g}^{-1}\right)$ & $\mathrm{R}^{2}$ & $\operatorname{TAL}\left(\mathrm{g} \mathrm{cm}^{2} \mathrm{dia}^{-1}\right)$ & $\mathrm{R}^{2}$ \\
\hline BRSM790A & $y=1,666 x^{2}-39,877 x+234,9$ & 0,99 & $y=5 E-06 x^{2}-0,0002 x+0,0013$ & 0,96 \\
\hline $\mathrm{BRS} 257$ & $Y=2,826 x^{2}-51,128 x+243$ & $0,99^{* *}$ & $y=-4 E-06 x^{2}-6 E-05 x+0,001$ & $0,99^{* *}$ \\
\hline A7002 & $y=0,326 x^{2}-24,66 x+229,63$ & $0,99^{* *}$ & $y=4 E-06 x^{2}-8 E-05 x+0,0007$ & $0,91^{* *}$ \\
\hline M8585 & $y=0,935 x^{2}-29,87 x+237,86$ & $0,98^{* *}$ & $y=5 E-06 x^{2}-8 E-05 x+0,0006$ & $0,95^{* *}$ \\
\hline Cultivares & $\operatorname{TCA}\left(\mathrm{g}^{1} \mathrm{dia}^{-1}\right)$ & $\mathbf{R}^{2}$ & $\operatorname{TCR}\left(\mathrm{g} \mathrm{g}^{1} \mathrm{dia}^{-1}\right)$ & $\mathbf{R}^{2}$ \\
\hline BRSM790A & $y=0,0105 x^{2}+0,001 x+0,152$ & $0,98^{\pi}$ & $y=0,0039 x^{2}-0,0604 x+0,239$ & 0,96 \\
\hline BRS257 & $y=-0,0013 x^{2}+0,085 x+0,013$ & $0,98^{* *}$ & $y=0,0035 x^{2}-0,0553 x+0,22$ & $0,97^{* *}$ \\
\hline A7002 & $y=0,01 x^{2}+0,0089 x+0,079$ & $0,99^{* *}$ & $y=0,0019 x^{2}-0,0316 x+0,150$ & $0,97^{* *}$ \\
\hline M8585 & $y=0,004 x^{2}+0,0511 x+0,010$ & $0,99^{* *}$ & $y=0,0024 x^{2}-0,0367 x+0,159$ & $0,97^{* *}$ \\
\hline
\end{tabular}

Fonte: Elaboração dos autores. 

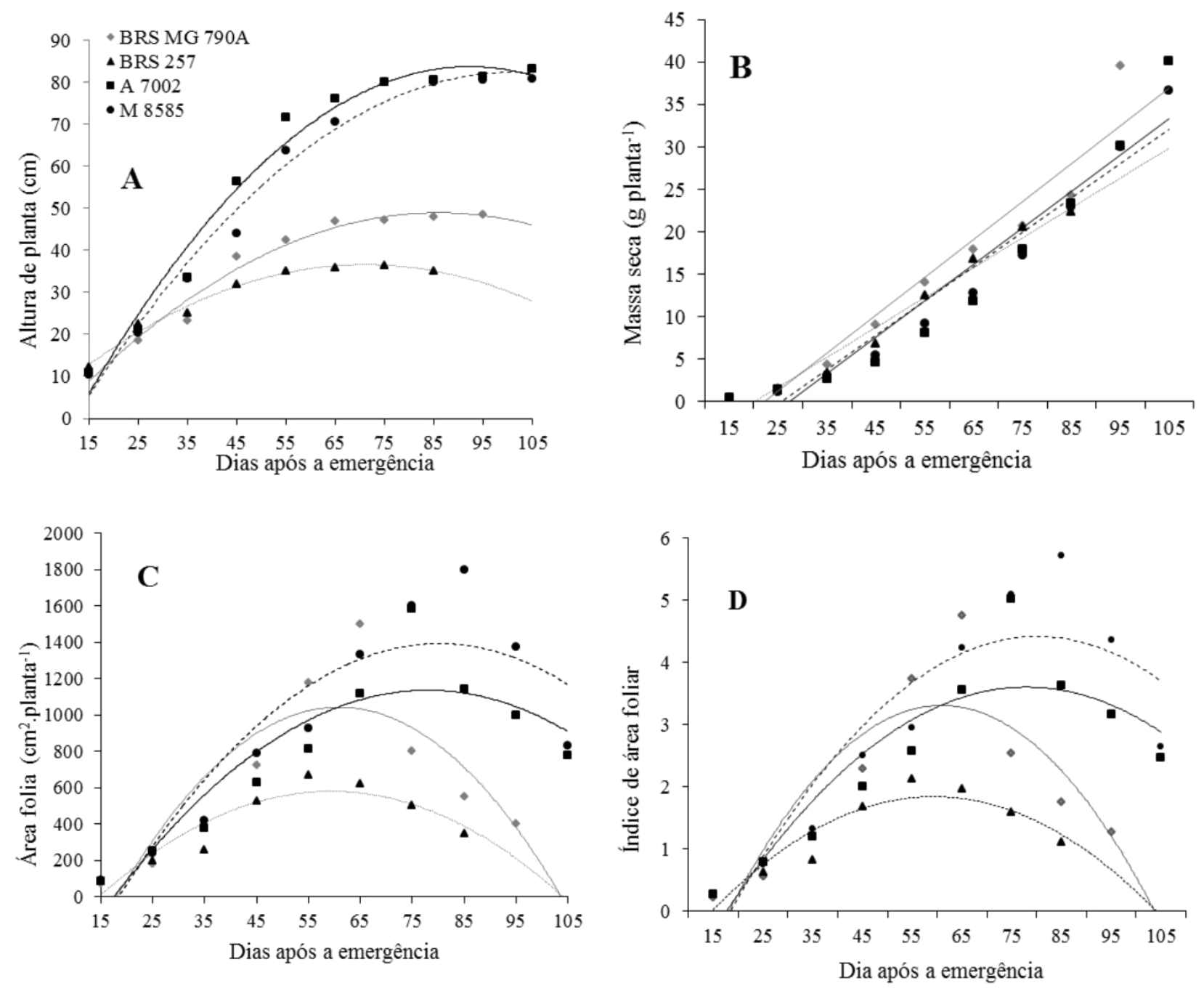

Figura 2: Atura de plantas (A), massa seca (B), área foliar (C) e índice de área foliar (D) de plantas de soja tipo alimento BRSMG 790A ( $(-)$, BRS 257(……) e tipo comum A7002 (- $)$ e M 8585 (------) cultivadas em Gurupi, TO, a $11^{\circ} 43$ ' Sul.

Verificou-se uma tendência de estabilização na altura da BRS 257 aos 45 DAE, e aos 55 DAE na BRSMG 790A. Nas cultivares A 7002 e M 8585 essa estabilização foi observada mais tardiamente a partir 65 DAE. Essas cultivares ainda apresentaram uma expressiva diferença na altura máxima de suas plantas, com média máxima de $82 \mathrm{~cm}$, enquanto a BRS 257 e BRSMG 
790A apresentaram altura média máxima de 36,5 e 48,6 cm, respectivamente. Também foi observada a resposta quadrática para o crescimento das plantas em soja cultivada em altas latitudes do norte (PEDERSEN; LAUER, 2004).

A altura da planta está diretamente relacionada com grupos de maturação, a resposta a duração do dia e a presença de periodo juvenil longo (SPEHAR et al., 2014). As cultivares do tipo de alimento, tiveram plantas baixas, resposta típica a condições de dias curtos prevalecentes no Tocantins, enquanto as plantas de soja tipo comum são altas para se adequar a colheita. Genótipos desprovidos de alelos juvenis começaram a floração a partir do estádio $\mathrm{V}_{3}$ em regiões tropicais, onde as plantas crescem sob curta duração do dia (ALMEIDA et al., 1999). Este florescimento precoce resulta em plantas de menores alturas, com impacto negativo direto na biomassa e produtividade de grãos (SPEHAR et al., 2014).

Para massa seca de plantas (MS) foram ajustados modelos lineares para as cultivares ao longo do tempo (Figura 2B). No entanto, observaram-se os maiores incrementos para A7002, M 8585 e BRSMG 790A, enquanto os menores valores foram mostrados pela BRS 257 (Figura 2B). Desde a emergência até 35 DAE diferenças entre as cultivares não foram significativas. Entre 45 e 75 DAE as cultivares tipos alimento apresentaram maior massa seca. Aos 85 DAE, no entanto, houve diferença entre as cultivares, a BRS 257 encerra-se o ciclo com MS acumulada de $22 \mathrm{~g}$. Aos 95 DAE a BRSMG 790A atingiu a maturidade com $40 \mathrm{~g}$ de matéria seca. Isto era esperado, considerando as diferenças no grupo de maturação. A maturação precoce da BRS 257 rendeu menos do que a BRSMG 790A e a diferença relacionada com o alargamento do ciclo da planta por mais de dez dias, como demonstrado à soja tipo comum (SPEHAR et al., 2014).

As cultivares A7002 e M 8585 comportaram-se de forma semelhante em acúmulo de matéria seca durante o ciclo da planta (Fig. 2B). As tipo alimento tenderam acumular maior 
biomassa durante um menor período, coincidindo com sua seleção e recomendação de áreas de latitude mais elevadas do sul. O ciclo de maturação (NDM) das cultivares do tipo de alimento (BRS 257 e BRSMG 790A) foi mais precoce do que as tipo comum (A 7002 e M 8585) coincidindo com sua seleção e recomendação de áreas de latitude mais elevadas do sul, fato que teve um impacto negativo sobre o número de vagens por planta e produtividade de grãos (Tabela $3)$.

Tabela 3. Médias de características agronômicas de cultivares de soja: tipo alimento (BRSMG 790A e BRS 257) e tipo comum (A7002 e M 8585) para avaliação de adaptação em Gurupi TO, localizado a $11^{\circ} 43^{\prime}$ sul.

\begin{tabular}{lccccc}
\hline \multirow{2}{*}{ Cultivares } & \multicolumn{5}{c}{ Características } \\
\cline { 2 - 6 } & NDF & NDM & NDPR & NVP & RG \\
\hline BRSMG 790A & $29 \mathrm{~b}$ & $96 \mathrm{c}$ & $67 \mathrm{~b}$ & $46 \mathrm{~b}$ & $1033 \mathrm{c}$ \\
RS 257 & $24 \mathrm{c}$ & $78 \mathrm{~d}$ & $54 \mathrm{c}$ & $29 \mathrm{c}$ & $583 \mathrm{~d}$ \\
A7002 & $31 \mathrm{~b}$ & $108 \mathrm{~b}$ & $77 \mathrm{a}$ & $70 \mathrm{a}$ & $3696 \mathrm{a}$ \\
M 8585 & $39 \mathrm{a}$ & $126 \mathrm{a}$ & $81 \mathrm{a}$ & $77 \mathrm{a}$ & $3180 \mathrm{~b}$ \\
\hline Média & 31 & 101 & 70 & 55 & 1858 \\
\hline
\end{tabular}

Médias seguidas de mesma letra na coluna não diferem pelo teste de Tukey $(\mathrm{P} \leq 0,05)$.

NDF: número de dias para o florescimento; NDM: número de dias para a maturação; NDPR número de dias do período reprodutivo, número de vagem por planta NVP e RG: rendimento de grãos.

A resposta linear à acumulação de massa seca foi similar à obtida com o gerbera (LUDWIG et al., 2013) enquanto resultados divergentes foram obtidos com arroz (ALVAREZ et al., 2012) e a soja (OLIVEIRA et al., 2013) onde os pesquisadores obtiveram curva sigmoides para produção de biomassa. No entanto, em altitudes mais baixas como Gurupi, onde o experimento foi realizado, as temperaturas mais elevadas contribuem para acelerar o ciclo da planta, quando 70 
consideradas em graus-dias (SPEHAR et al., 2014), justificando a resposta de crescimento apresentado.

A área foliar (AF) e índice de área foliar (IAF), ajustada a modelo quadrático (Tabela 2) e mostrou tendência semelhante (Fig. 2C e 2D). As cultivares não apresentaram diferenças significativas em AF e IAF para os primeiros 25 DAE. O máximo de área foliar aconteceu a 55 DAE para BRS 257 e aos 65 DAE para BRSMG 790A. Após este período, houve uma redução em AF e IAF, na fase reprodutiva os fotoassimilados e minerais são translocados para os grãos, provocando a senescência das folhas mais velhas. Isso foi observado quando se comparam as cultivares de soja do tipo comum e soja do tipo de alimento, as quais apresentaram os menores valores tanto para AF e IAF.

O índice de área foliar mede a área de cobertura do solo representado pelas folhas na planta (PRICE; MUNNS, 2010). Os valores dos índices das cultivares introduzida do tipo de alimento foram notóriamente mais baixos quando comparados com as cultivares tipo comum que foram selecionadas localmente. Salienta-se que a BRS 257 apresentou menor AF e IAF de apenas 2,13, enquanto o IAF máximo para as cultivares M 8585 e A 7002 foi superior a cinco como seria de esperar (NGUY-ROBERTSON et al., 2012). O IAF máximo ocorreu em momentos diferentes entre as cultivares, justificando a diferença varietal no grupo condicionado por resposta a curta duração do período do dia. Os valores máximos para IAF foram observados aos 55 DAE para BRS 257, aos 65 DAE para BRSMG 790A, aos 75 DAE para A 7002 e aos 85 DAE para M 8585 essas diferenças podem também ser associados a resposta de alta temperatura (SPEHAR et al., 2014).

Houve declínio no IAF após a produção máxima da AF para todas as cultivares, esse fato, pode ser atribuído ao direcionamento dos fotoassimilados aos grãos em formação, não só para 
atender o acúmulo crescente de matéria seca, mas também, da biossíntese de óleo e de proteína nas sementes (HEIFFIG et al., 2006). Além disso, a rápida drenagem causou redução na área foliar útil, levando a senescência e queda das folhas mais velhas (CAMPOS et al., 2008).

$\mathrm{O}$ índice de área foliar na soja em $\mathrm{R}_{1}$ deve ser de 5.5 para obtenção de alto rendimento (NGUY-ROBERTSON et al., 2012). Assim, quanto mais rápido a obtenção desse índice maior será o indicativo de adequação das plantas no tempo e no espaço, o que permite maior produtividade de grãos. Os valores de IAF mais baixos para BRS 257 explicam a redução de rendimento significativo relatado aqui. Os fatores ambientais como temperatura e duração do dia têm efeito direto sobre IAF, dependendo da latitude, altitude, data e características genotípicas semeadura. Este experimento foi conduzido em condição de dias curtos, fazendo com que ocorrece a indução de florescimento antecipado nas cultivares que não apresentam alelos de periodo juvenil longo (SPEHAR et al., 2014). Como resultado da floração precoce há um menor o crescimento da planta, com a redução da AF, implicando em menor número de vagens e grãos.

A razão de área foliar (RAF), correspondente à relação entre a resposta de área foliar para interceptação de luz, CO2 e matéria seca. Essa taxa declina durante o crescimento da planta, em função do sombreamento e consequente redução da área fotossinteticamente ativa (PRICE; MUNNS, 2010 ). A RAF ajustou ao modelo quadrático com R $^{2}$ variando de 0,98 e 0,99 (Tabela 2). Ela foi máxima aos 15 DAE para todas as cultivares, com um declínio contínuo em seguida (Fig. 3A). As cultivares dividiram-se em dois grupos distintos, onde as tipo de alimento tiveram os menores valores. As menores RAF foram obtidas no final do ciclo, aos 85 DAE a BRS 257, de 95 DAE a BRSMG 790A e 105 DAE para A7002 e M8585. 

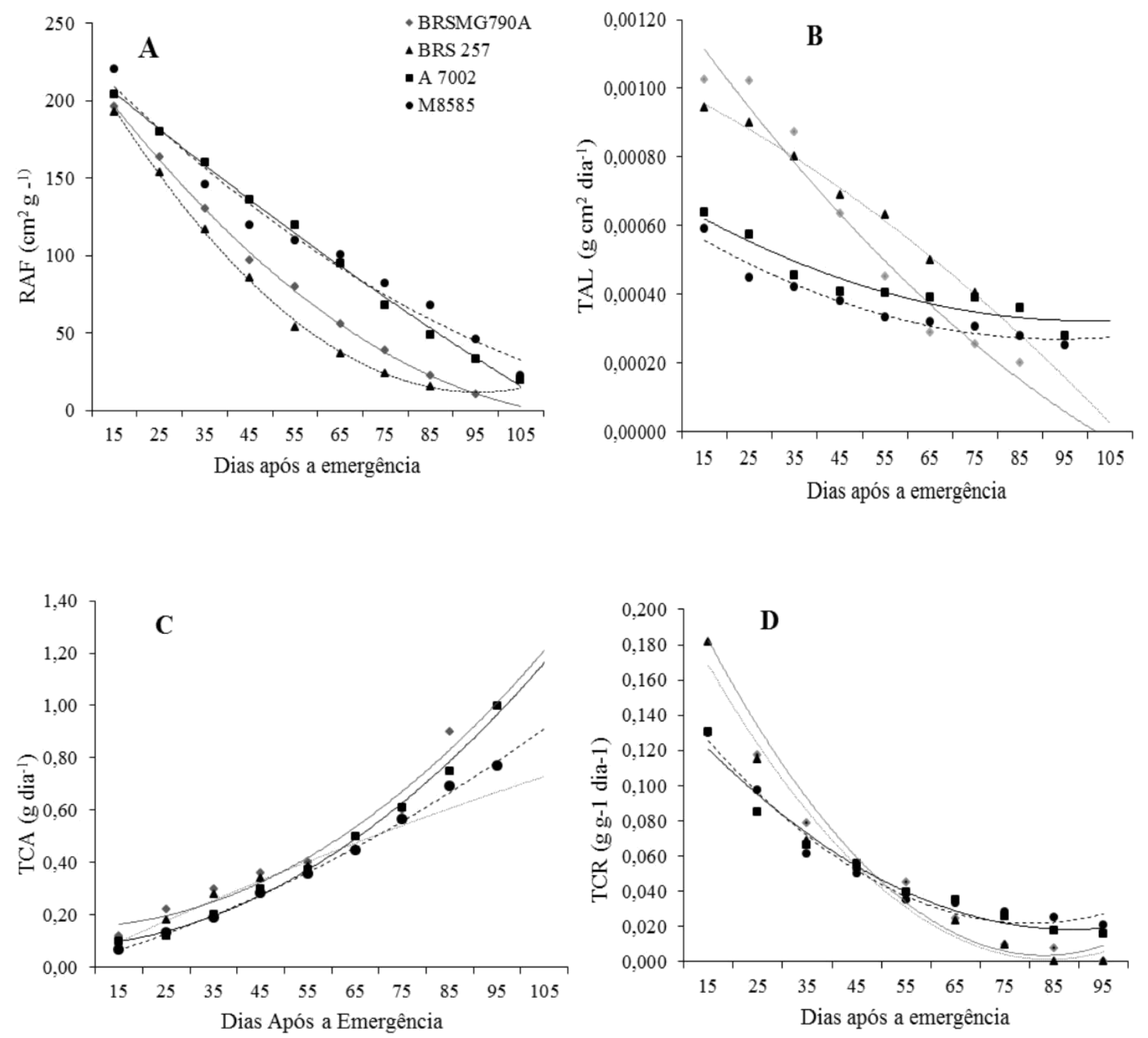

Figura 3: Razão de área foliar (RAF) (A), taxa de assimilação liquida (TAL) (B), taxa de crescimento absoluto (TCA) (C) e taxa de crescimento relativo (TCR) (D) de plantas de soja tipo alimento BRSMG790A (一), BRS 257(……) e tipo comum A7002 (- $)$ e M 8585 (------) cultivadas em Gurupi, TO, a $11^{\circ} 43^{\prime}$ Sul.

A RAF mostrou alto valor no início do ciclo da planta como demonstrado aqui, pois há maior atividade fotossintética, pela expansão foliar e interceptação de luz (LUDWIG et al., 2010). Os valores da RAF declinam ao longo do ciclo da planta devido ao sombreamento das 
folhas superiores às folhas inferiores. Há uma relação inversa entre a área foliar e razão de área foliar, as plantas fixam mais carbono em baixa AF. Tendência semelhante da RAF também foi verificada na cultura do Tomate (MARTINAZZO et al., 2015).

A taxa de assimilação líquida (TAL) representa o equilíbrio entre o produto da fotossíntese e as perdas devido à respiração, indicando a eficiência da planta na produção de matéria seca. A TAL foi ajustada ao modelo quadrático onde o $\mathrm{R}^{2}$ variou de 0,91 para A 7002 a 0,99 para BRS 257 (Tabela 2). A TAL decresceu gradativamente em todos cultivares no experimento (Figura 3B).

As cultivares destinadas ao consumo humano, BRSMG 790A e BRS 257, apresentaram maior TAL no início do ciclo sendo superior nas do tipo comum, M 8585 e A 7002, até os 45 e 65 DAE, respectivamente. As cultivares do tipo comum tenderam apresentar o mesmo comportamento ao logo do período avaliado, ou seja, não apresentando variação significativa entre elas. Esse desempenho ocorreu, possivelmente devido ao período vegetativo prolongado, com menores índices iniciais da fotossíntese, mas mantida durante o ciclo da planta por mais tempo, indicando a sua capacidade de adaptação ao crescimento sob baixa latitude e alta temperatura. A tendência encontrada aqui divergiu daqueles com plantas de feijão-caupi e tomate; onde a TAL oscilou durante o ciclo das plantas (FREITAS et al., 2014. MARTINAZZO et al., 2015).

Os valores da taxa de crescimento absoluto (TCA) foram ajustados a equações do modelo quadrático para $\mathrm{R}^{2}$ entre 0,98 e 0,99 (Tabela 2). O crescimento inicial das plantas foi lento até 35 DAE (Fig. 3C). Aos 75 DAE todas as cultivares apresentaram TCA semelhante, mas, depois disso, as cultivares do tipo comum apresentaram valores crescentes superando as cultivares do tipo de alimentos. 
A taxa de crescimento relativo (TCR) foi decrecentes apresentando comportamento similar aos observados para RAF e TAL (Fig. 3D). As equações TCR foram significativas para a resposta quadrática com $\mathrm{R}^{2}$ de 0,96 e 0,97 (Tabela 2).

As cultivares formaram dois grupos de soja: tipo comum e tipo de alimentos. Dentro do grupo, não houve diferença significativa entre as cultivares fato que contribuiu para esse agrupamento. Da emergência aos 35 DAE, as cultivares do tipo alimento apresentaram maior TCR e não diferiu da soja do tipo comum até os 45 e 55 DAE. Após este período as tipo comum sobressaíram as demais. A tendência dos dados para TCR corroboraram aos de Souza et al. (2016) em plantas de café. O aumento e declínio da TCR ao longo do ciclo da planta estão associados a flutuações na taxa de assimilação líquida (FREITAS, et al., 2014).

Os valores médios de NDF, NDM, NDPR, NVP e RG (Tabela 3) confirma a falta de adaptação da soja tipo de alimento BRSMG 790A e BRS 257, em decorrência da precocidade, tanto do florescimento quanto da maturação, consequentemente resultando em menor rendimento de grãos. A BRS 257 foi a mais precoce florescendo aos 24 DAE e encerrando o ciclo aos 78 DAE. Como consequência foi a menos produtiva, sendo 82 e $84 \%$ inferior as M 8585 e A7002, respectivamente. Esses resultados estão de acordo para a BRS 257, estão de acordo com os verificados por Santos et al. (2011b) quando cultivada em Formoso do Araguaia - TO.

A cultivar tipo alimento BRSMG 790A apresentou um ciclo de 96 dias e igualou significativamente a 7002 quanto ao NDF. No entanto, o seu período reprodutivo foi inferior a 10 dias fato que contribuiu para a redução no rendimento de grãos. As cultivares tipo de comum produziram $2405 \mathrm{~kg} \mathrm{ha}^{-1}$ superior a BRSMG 790A. A diferença de 12 dias no ciclo também influenciou negativamente a altura das plantas uma vez que a BRSMG 790A foi em média 41\% 
inferior a A7002 e M 8585 (Figura 2A). A AP influenciou nos componentes produtivos como NVP e RG.

As medições de análise de crescimento como área foliar, índice de área foliar, razão de área foliar, taxa de assimilação líquida e taxa de crescimento relativo foram eficientes para demonstrar a falta de adaptação da BRSMG 790A e BRS 257 na latitude $11^{\circ} 43^{\prime}$. Isto foi corroborado pelas características agronômicas como o número de dias para o florescimento, número de dias para a reprodução, número de vagens por planta e a produtividade de grãos.

Mesmo que as cultivares do tipo alimento (BRS 257 e BRSMG 790A) não tenha apresentado capacidade de adaptação às baixas latitudes do Estado do Tocantins, elas poderam ser úteis em programas de melhoramento para cruzar com genótipos de periodo jovenil longo como A7002 e M 8585. Ambos apresentam em sua constituição genética alelos que condicionam periodo junil longo e alelos dominantes para lipoxigenase que condiciona a presença de lipoxigenase (CARPENTIERI-PIPOLO et al., 2009;. LENIS et al., 2010). Os possíveis recombinantes devem apresentar ambas características de periodo juvenil longo e ausência de lipoxigenases.

\subsection{CONCLUSÕES}

As cultivares tipo alimento apresentaram baixos índices fisiológicos quando cultivada em $11^{\circ} 43^{\prime}$ de latitude sul.

A cultivar tipo alimento BRS 257 apresentou os menores valores para os caracteres agronômicos.

Baseado na análise de crescimento e nos caracteres agronômicos não recomenda-se o cultivo 
comercial das cultivares BRS790A e BRS 257 na latitude $11^{\circ} 43^{\prime}$ sul.

Análise de crescimento foi eficiente para quantificar a resposta biológica de soja do tipo alimento, quando cultivada em baixas latitudes.

A soja do tipo alimento é útil em programas de melhoramento genético de plantas visando à obtenção de genótipos com periodo juvenil longo e livre de lipoxigenase.

\subsection{REFERÊNCIAS}

ALVAREZ, R. C. F.; CRUSCIOL, C. A. C.; NASCENTE, A. S. Análise de crescimento e produtividade de cultivares de arroz de terras altas dos tipos tradicional, intermediário e moderno. Pesq. Agropec. Trop. v. 42, n. 4, p. 397-406, 2012.

ANDRADE JÚNIOR, A. S.; IRENE FILHO, J.; FERREIRA, J. O. P.; RIBEIRO, V. Q.; BASTOS, E. A. Medidas de crescimento em cultivares de feijão-caupi submetidas a diferentes regimes hídricos. Comunicata Scientiae, n. 5, v. 2, p. 187-195, 2014.

ALMEIDA, L. A.; KIIHL, R. A. S.; MIRANDA, M. A. C.; CAMPELO, G. J. A. Melhoramento da soja para regiões de baixas latitudes, In Recursos genéticos e melhoramento de plantas para o nordeste brasileiro. QUEIROZ, M. A.; GOEDERT, C. O.; RAMOS, S. R. R. eds. 1999.

CAMPOS, M. F.; ONO, E. O.; FERnANDES, C. S.; RODRIGUES, B. J. D. Análise de crescimento em plantas de soja tratadas com substâncias reguladoras. Revista Biotemas, v. 21, n. 3, p. 53-63, 2008. 
CARPENTIERI-PIPOLO, V.; ALMEIDA, L. A.; KIIHL, R. A. S.; ROSOLEM, C. A. Inheritance of long juvenile period under short day conditions for the BR80-6778 soybean (Glycine max (L.) Merrill) line. Euphytica, v. 112, p. 203-209, 2000.

CARRÃO-PANIZZI, M. C.; SILVA, J. B. DA. Soja na alimentação humana: qualidade na produção de grãos com valor agregado. In: Congresso da soja no Mercosul, 2011, Rosário. Anais..., Rosário: ACSOJA, 2011.

CRUZ, T. V.; PEIXOTO, C. P.; MARTINS, M. C. Crescimento e produtividade de soja em diferentes épocas de semeadura no oeste da Bahia. Scientia Agraria, v.11, n.1, p.33-42, 2010.

DAUGHTRY, C. S. T. Direct measurements of canopy structure. In: GOEL, N. S., NORMAN, J. M. Instrumentation for studying vegetation canopies for remote sensing in optical and thermal infrared regions. Remote sensing reviews, v. 5, n. 1, p: 45-60, 1990. cap. 4.

FEHR, W. R.; CAVINESS, C. E.; BURMOOD, D .T.; PENNINGTON, J. S. Stage of development descriptions for soybeans, Glycyne max L. Merril. Crop Science, v. 11, p. 929-931, 1971.

FREITAS, R. M. O.; DOMBROSKI, J. L. D.; FREITAS, F.C. L.; NOGUEIRA, N. W.; PINTO, J. R. S. Crescimento de feijão-caupi sob efeito de veranico nos sistemas de plantio direto e convencional. Bioscience Journal, v. 30, n. 2, p. 393-401, 2014. 
HEIFFIG, L. S.; Câmara, G. M. S.; M. L. A.; Pedroso, D. B.; Piedade, S. M. S. Fechamento e índice de área foliar da cultura da soja em diferentes arranjos espaciais. Bragantia, v. 65, n. 2, p. 285-295, 2006.

HOFFMANN, W. A.; POORTER, H. Avoiding bias in calculation of relative growth rate. Annals of Botany, 91:685-689, 2002.

IUSS WORKING GROUP W. R. B. World Reference Base for Soil Resources 2014, update. International soil classification system for naming soils and creating legends for soil maps.

World Soil Resources Reports, n. 106. FAO, Rome, 2015.

KOTTEK, M.; GRIESER, J.; BECK, C.; RUDOLPH, B.; RUBEL, F. World Map of the KöppenGeiger climate classification updated. Meteorologische Zeitschrift, v. 15, p. 259-263, 2006.

LENIS, J. M.; GILlMAN, J. D.; LEE, J. D.; SHANNON, J. G.; BILYEU, C. Soybean seed lipoxygenase genes: molecular characterization and development of molecular marker assays.

Theoretical and Applied Genetics, v. 120, p. 1139-1149, 2010.

LUDWIG, F.; GUERRERO, A. C.; FERNANDES, D. M.; BOAS, R. L. V. Análise de crescimento de gérbera de vaso conduzida em diferentes substratos. Horticultura Brasileira, v. 28, p. 70-74, 2010. 
LUDWIG, F.; GUERRERO, A. V.; GONÇALVES, S. O.; FERNANDES, D. M.; VILLAS BÔAS, R. L. Lâminas de fertirrigação e substratos na produção e qualidade de gérbera de vaso. Irriga, v. 18, n. 4, p. 635-646, 2013.

MARTINAZZO, E. G.; PERBONI, A. T.; POSSO, D. A.; AUMONDE, T. Z.; BACARIN, M. A. Análise de crescimento e partição de assimilados em plantas de tomateiro cv. Micro-Tom submetidas ao nitrogênio e piraclostrobina. Semina: Ciências Agrárias, v. 36, n. 5, p. 3001$3012,2015$.

MEHMET SINCIK, A.; GÖKSOY, T.; ETIN TURAN, Z. How growth dynamics affect soybean development across cultural practices, Soybean. In: Ng, T (Ed.) Soybean applications and technology. ISBN, 978-953-307-207-4, 2011, InTech: available in $<\mathrm{http}: / /$ www.intechopen.com/books/soybean-applications-andtechnology/how-growth-dynamicsaffect-soybean-development-across-cultural-practices>.

MORRISON, M. J.; VOLDENG, H. D.; COBER, E. R. Physiological Changes from 58 Years of Genetic Improvement of Short-Season Soybean Cultivars in Canada. Crop Science, v. 91, p. 685-689, 1999.

NGUY-ROBERTSON, A.; GITELSON, A.; PENG, Y.; VIÑA, A.; ARKEBAUER, T.; RUNDQUIST, D. Green Leaf Area Index Estimation in Maize and Soybean: Combining Vegetation Indices to Achieve Maximal Sensitivity. Agronomy Journal, v. 10, n. 1336-1347, 2012. 
OLIVEIRA, P.; NASCENTE, A. S.; KLUTHCOUSKI, J. Soybean growth and yield under cover crops. Rev. Ceres, v. 60, n. 2, p. 249-256, 2013.

PEDERSEN, P.; LAUER, J. G. Soybean growth and development in various management systems and planting dates. Crop Science, n. 44, p. 508-515, 2004.

PRICE, C.; MUNNS, R. 2010. Growth analysis: a quantitative approach. In: MUNNS, R.; SCHMIDT, S.; BEVERIDGE, C. (Eds.) Plants in action. Australian Society of Plant Scientists, New Zealand Society of Plant Biologists, and New Zealand Institute of Agricultural and Horticultural Science.

SANTOS, E. R., BORGES, P. R. S., SIEBENEICHLER, S. C., CERQUEIRA, A. P., PEREIRA, P. R. Crescimento e teores de pigmentos foliares em feijão-caupi cultivado sob dois ambientes de luminosidade. Revista Caatinga, n. 24, p. 14-19, 2011a.

SANTOS, E. R.; BARROS, H. B.; FERRAZ, E. C.; CELlA, A. J.; CAPONE, A.; SANTOS, A. F.; FIDELIS, R. R. Divergência entre genótipos de soja, cultivados em várzea irrigada. Rev. Ceres, v. 58, n.6, p. 755-764, 2011 b.

SANTOS, V. M.; CASTRO, H. G.; CARDOSO, D. P.; LIMA, S. O.; LEAL, T. C. A. B.; SANTOS, G. R. Avaliação do crescimento e da produtividade da mamoneira BRS 149, 
Nordestina em dois níveis tecnológicos. Journal of Biotecnology and Biodiversity, v. 2, p. 5866, 2011c.

SILVA, J. B.; CARRÃO-PANIZZI, M. C.; PRUDÊNCIO, S. H. Chemical and physical composition of grain-type and food-type soybean for food processing. Pesquisa Agropecuária Brasileira, v. 44, p. 777-784, 2009.

SILVA, J. B.; CARRÃO-PANIZZI, M. C.; MANDARINO, J. M. G.; LEITE, R. S.; MÔNACO, A. P. A. Isoflavone contents of whole soybeans and their components, obtained from different cultivars (Glycine $\max$ (L.) Merrill). Brazilian Journal of Food Technology, v. 15, p. 150-156, 2012.

SOUZA, A. J. J.; GUIMARÃES, R. J.; COLOMBO, A., SANT'ANA, J. A. V.; CASTANHEIRA, D. T. Quantitative analysis of growth in coffee plants cultivated with a waterretaining polymer in an irrigated system. Revista Ciência Agronômica, v. 47, n. 1, p. 162-171, 2016.

SPEHAR, C. R., FRANCISCO, E. R.; PEREIRA, E. A. Yield stability of soybean cultivars in crop seasons and sowing dates at low latitude Brazilian Savannah Highlands. Journal of Agricultural Science, v. 153, p. 1059-1068, 2014.

YUSUF, I. R.; SIEMENS, J. C.; BULLOCK, D. G. Growth analysis of soybean under no-tillage and conventional tillage systems. Crop Science, v. 91, p. 928-933, 1999. 
CAPÍTULO 2. PARÂMETROS GENÉTICOS E AVALIAÇÃo AGRONÔMICA EM PROGENIES F $F_{2}$ DE SOJA NO DISTRITO FEDERAL

CHAPTER 2. GENETIC PARAMETERS AND AGRONOMIC EVALUATION PROGENIES F2 SOY THE FEDERAL DISTRICT 


\section{RESUMO}

Este estudo teve como objetivo avaliar a variabilidade existente entre progênies de soja, na geração $F_{2}$, oriundas de vinte cruzamentos biparentais, entre genitores com caracteres especiais, destinadas a alimentação humana e genitores que apresentam período juvenil longo, por meio de características agronômicas e componentes genéticos. O experimento foi conduzido na Fazenda Água Limpa, UnB - DF, no ano agrícola 2013/14. O delineamento experimental adotado foi o de blocos casualizados com quatro repetições. Foram avaliadas as características agronômicas e estimada a herdabilidade e a relação entre o coeficiente de variação genético e ambiental. Foram calculadas ainda, as correlações fenotípicas entre os caracteres. A hibridação entre cultivares com período juvenil longo e de cultivares com ausência de lipoxigenase originou grande variação no número de dias para a maturação em soja. O cruzamento Amaralina x UFVTN105 apresentou maior probabilidade de selecionar para altura de plantas, enquanto o cruzamento UFVTN105 x M 8867 apresentou maior frequência de recombinantes com produtividade. A seleção por número de dias para a maturação e altura de plantas foi efetiva na geração $F_{2}$ para se obter soja sem lipoxigenase, com base no razão $\mathrm{CVg} / \mathrm{CV}$ e. Correlações positivas e significativas de magnitude forte entre as variáveis NDM x AP e NV x RG e de magnitude mediana entre AP x AIV, indicam a possibilidade de ganho por seleção para soja produtiva e sem lipoxigenase.

Palavras-chave: Glycine max, Seleção precoce, resposta a seleção, herdabilidade, razão CVg / CVe. 


\begin{abstract}
This study aimed to evaluate the variability among soybean progeny in the $\mathrm{F}_{2}$ generation, coming from twenty two-parent crosses between parents with special characters, intended for human consumption and parents which have long juvenile period, through agronomic traits and genetic components. The experiment was conducted at Água Limpa Farm, UnB - DF in the 2013/2014 crop season. The experimental design was a randomized block with four replications. Agronomic characteristics were evaluated and used to estimate heritability and the relationship between the coefficient of genetic and environmental variation. It was also calculated the correlations between characters. The hybridization among cultivars with long juvenile period and cultivars with free-lipoxygenase caused great variation in the number of days for maturation. The Amaralina x UFVTN 105 crossing is more likely to yield desirable genotypes for plant height, while the UFVTN 105 x M 8867 crossing has a higher frequency of recombinants with productivity. The selection by number of days to maturity and plant height is effective in the $\mathrm{F}_{2}$ generation to obtain free-lipoxygenase soybean, based on $\mathrm{CVg} / \mathrm{CVe}$ ratio. Positive and significant correlations of strong magnitude between variables number of days do maturity $\mathrm{x}$ plant height and number of pods per plant $\mathrm{x}$ grain yield and intermediate magnitude between plant height $\mathrm{x}$ first pod height indicate the possibility of gain from selection for productive and freelipoxygenase soybean.
\end{abstract}

Key words: Glycine max, Early selection, response to selection, heritability, CVg / CVe ratio. 


\subsection{INTRODUÇÃO}

O Brasil foi segundo maior produtor de soja (Glycine max. (L.) Merrill) no mundo na safra 2014/15, sendo superado apenas pelos Estados Unidos da América. Da soja brasileira, a maior parte é exportada e usada para ração animal. Entretanto, o consumo na alimentação humana entre os brasileiros tem aumentado em decorrência dos benefícios a saúde e aumento da oferta de produtos à base de soja de melhor qualidade no mercado. A principal razão do baixo uso para consumo humano deve-se ao sabor desagradável "beany flavour", atribuído à presença de enzimas do tipo lipoxigenase (TSUKAMOTO et al., 2001).

Apesar da cultura da soja estar disseminada por todo o país ainda existem poucos cultivares destinados à alimentação humana, tornando necessária a obtenção de cultivares para as diferentes regiões de cultivo, principalmente áreas de cerrado de menores latitudes. Os cultivares disponíveis destinados a esse fim quando introduzidos em regiões de baixa latitude apresentam reduzido crescimento de planta e baixo rendimento de grãos. Um dos principais fatores que afetam o desenvolvimento e a produtividade da soja é o fotoperíodo. A espécie floresce sob dias curtos (FIETZ; RANGEL, 2008).

Os programas de melhoramento de soja exerceram influência marcante sobre o desenvolvimento dessa leguminosa no Brasil (VASCONCELOS et al., 2015). A maior parte do território brasileiro encontra-se em regiões tropicais, com baixa amplitude entre o dia mais longo e o mais curto do ano. Portanto, a soja adaptada às baixas latitudes apresenta um componente genético que a difere das regiões tradicionais de cultivo. Trata-se do período juvenil longo (PJL), alongando a fase vegetativa da soja sob condições de dias curtos (SPEHAR et al., 2014). 
Portanto, espera-se que a variabilidade genética nos programas de melhoramento de soja às baixas latitudes, incorpore alelos de período juvenil longo, possibilitando seleção de recombinantes com características agronômicas e de rendimento, resultando ganhos genéticos significativos (MUNIZ, 2007). Avanços na seleção de soja comum, com lipoxigenase, são demonstrados por crescimento de plantas e aumentos no período vegetativo e rendimento (SPEHAR et al, 2014). A soja com ausência de lipoxigenase, em contraste, não incorpora alelos de período juvenil, encurtando o ciclo da planta em baixas latitudes (SANTOS et al., 2011 ).

A solução para contornar essa limitação consiste em hibridar soja tipo alimento com soja comum contendo alelos de período juvenil longo (SANTOS et al., 2011 ). O teste em gerações iniciais, após hibridações, tem sido utilizado no melhoramento de espécies autógamas para avaliar o potencial das progênies $F_{2}$ ou $F_{3}$ em gerar linhagens agronomicamente superiores (ST MARTIN; GERALDI, 2002). Esse método permitiu eliminar progênies de baixo potencial agronômico, concentrando-se esforços e recursos naquelas que reúnem caracteres de interesse.

O método baseado na premissa de que o desempenho de progênie em gerações precoces permite prever o desempenho das linhas puras dela derivadas (CARVALHO et al., 2009). Ademais, as estimativas de parâmetros genéticos em gerações iniciais possibilitam dirigir o processo de seleção dos genótipos mais promissores (COSTA et al., 2008), além de definir genitores com maior probabilidade de gerar recombinantes livres de interações indesejáveis (ST MARTIN et al., 2009).

A estimativa de parâmetros genéticos torna possível conhecer a estrutura genética das populações, permitindo a seleção dos genótipos que se destacaram. Ainda, ao se estimarem os parâmetros genéticos de populações permite escolher o método de melhoramento mais eficiente para cada caso (VILELA, 2008). 
A herdabilidade é uma referência importante para o melhorista de plantas, por expressar a razão entre variância genética e variância fenotípica, onde esta última corresponde à variância genotípica e a ambiental. O coeficiente de herdabilidade não é uma propriedade de um caráter em si, mas a propriedade de um caráter para determinada população avaliada em ambiente específico (GILIOLI et al., 1980). Assim, valores de herdabilidade não são extrapoláveis para outras populações ou condições de ambiente, diferentes daquele em que foi estudado. A mais importante função da herdabilidade no estudo genético de um caráter métrico é o seu papel preditivo, expressando a confiança do valor fenotípico como um guia para o valor genético (DESTRO et al.,1987).

O coeficiente de correlação é outro parâmetro de importância, no melhoramento, entre os caracteres. A existência de correlação entre caracteres pode ser atribuída à ação dos mesmos fatores genéticos ou à resposta semelhante às condições ambientais, podendo-se selecionar por associação entre eles (OLIVEIRA et al., 2000).

Este estudo teve como objetivo avaliar a variabilidade existente entre progênies de soja, na geração $\mathrm{F}_{2}$, oriundas de vinte cruzamentos biparentais, entre genitores com caracteres especiais, destinadas a alimentação humana e genitores que apresentam período juvenil longo, por meio de características agronômicas e componentes genéticos.

\subsection{MATERIAL E MÉTODOS}

Os cruzamentos foram realizados na Estação Experimental de Biologia da Universidade de Brasília. Os genitores utilizados nos cruzamentos e suas principais características morfológicas 
encontram-se na Tabela 1. Os tratamentos testados encontram-se na Tabela 2, que foi constituído por 20 cruzamentos efetivos.

Tabela 1. Características morfológicas - cor da flor (CF), cor da pubescência (CP), cor do tegumento (CT) - origem e natureza da instituição (NI) de genótipos de soja utilizados em hibridações.

\begin{tabular}{|c|c|c|c|c|c|}
\hline Genótipo & $\mathbf{C F}$ & $\mathbf{C P}$ & CT & Origem & $\mathbf{N} \mathbf{I}$ \\
\hline $1-\mathrm{M} 8867^{1}$ & $\mathrm{~B}$ & $\mathrm{C}$ & A & Monsoy & Privada \\
\hline 2- M $9144^{1}$ & $\mathrm{R}$ & $\mathrm{C}$ & A & Monsoy & Privada \\
\hline $3-\mathrm{M} 8585^{1}$ & B & $\mathrm{C}$ & $\mathrm{A}$ & Monsoy & Privada \\
\hline 4- Conquista ${ }^{1}$ & $\mathrm{R}$ & M & A & Embrapa & Pública \\
\hline 5- BRSGO Amaralina ${ }^{1}$ & B & M & A & Embrapa & Pública \\
\hline 6- BRS $257^{4}(\mathrm{TN})$ & B & $\mathrm{C}$ & A & Embrapa & Pública \\
\hline 7- BRSMG $800 \mathrm{~A}^{3}$ & $\mathrm{R}$ & $\mathrm{C}$ & M & Embrapa & Pública \\
\hline 8- BRSMG 790A 3 & $\mathrm{R}$ & $\mathrm{C}$ & A & Embrapa & Pública \\
\hline 9- A $7002^{1}$ & $\mathrm{R}$ & $\mathrm{C}$ & A & Nidera & Privada \\
\hline $10-\mathrm{CD} 219^{1}$ & B & $\mathrm{C}$ & A & Coodetec & Cooperativa \\
\hline $11-\mathrm{DM} 309^{1}$ & B & M & A & Agropec. Dois Marcos & Privada \\
\hline 12- UFVTN105 & $\mathrm{R}$ & $\mathrm{C}$ & $\mathrm{A}$ & UFV & Pública \\
\hline $13-\mathrm{UnB} 1125^{2}$ & $\mathrm{R}$ & M & $\mathrm{P}$ & $\mathrm{UnB}$ & Pública \\
\hline 14- Linhagem Preta ${ }^{2}$ & $\mathrm{R}$ & M & $P$ & UnB & Pública \\
\hline $15-\mathrm{HCSI}^{5}$ & $\mathrm{R}$ & $\mathrm{C}$ & $\mathrm{A}$ & - & - \\
\hline \multicolumn{6}{|c|}{$\begin{array}{l}{ }^{1} \text { Soja com PJL de interesse para a indústria de óleo e farelo cultivada na região do Cerrado; } \\
\text { UnB } 31125 \text { e Linhagem Preta genótipos com tegumento pretos e PJL, selecionados na } \\
\text { UnB; }{ }^{4} \text { Soja destinada a alimentação humana, indicadas ao cultivo em MG, SP, GO e DF; } \\
\text { Soja para alimentação humana, com alelos recessivos para as três enzimas lipoxigenases } \\
\text { (TN) } 5 \text { Genótipo com hábito de crescimento semideterminado. } \\
\text { B: branca; R: roxa; C: cinza; M: marrom; } \\
\text { A: amarelo; M: marrom; P: preto. }\end{array}$} \\
\hline
\end{tabular}


Tabela 2. Tratamentos testados - vinte cruzamentos, com seus genitores femininos (GF) e masculinos (GM).

\begin{tabular}{ccllll}
\hline \multicolumn{1}{c}{ GF } & & GM & GF & & GM \\
\hline 1- BRS 257 (TN) & x & CD 219 (PJL) & 11- M 8585 (PJL) & x & BRSMG 800A \\
2- BRS 257 (TN) & x & DM 309 (PJL) & 12- M 8585 (PJL) & x & BRSMG 790A \\
3- BRS 257 (TN) & x & M 8867 (PJL) & 13- M 8585 (PJL) & x & BRS 257 (TN) \\
4- BRS 257 (TN) & x & M 9144 (PJL) & 14- UFVTN105 (TN) & x & M 9144 (PJL) \\
5- BRS 257 (TN) & x & HCSI & 15- UFVTN105 (TN) & x & M8867 (PJL) \\
6- BRS 257 (TN) & x & A 7002 (PJL) & 16- UFVTN105 (TN) & x & M 8585 (PJL) \\
7- BRS 257 (TN) & x & Conquista (PJL) & 17- BRSMG 800A & x & A 7002 (PJL) \\
8- BRS 257 (TN) & x & UnB 1125 (PJL) & 18- Conquista & x & UFVTN105 (TN) \\
9- BRS 257 (TN) & x & Preta (PJL) & 19- Amaralina (PJL) & x & UFVTN105 (TN) \\
10- M 8585 (PJL) & x & UFVTN105 (TN) & 20- M 9144 (PJL) & x & UFVTN105 (TN) \\
\hline
\end{tabular}

TN: Triplo nulo (ausência de lipoxigenases).

Nas hibridações utilizaram-se como genitores masculinos oito cultivares de soja que apresentam PJL. A seleção foi baseada no desempenho agronômico na Região dos cerrados e na dissimilaridade genética. Para genitores femininos empregaram-se quatro cultivares destinados à alimentação humana. Buscou-se, quando possível utilizar marcadores morfológicos recessivos no momento de decidir o genitor feminino, a fim de identificar precocemente o sucesso da hibridação. Observou-se principalmente cor da flor e da pubescência, onde o genitor feminino foi prioritariamente portador de alelos recessivos (flor branca e pubescência cinza).

Os cruzamentos foram realizados em casa de vegetação na Estação Experimental de Biologia da UnB. As sementes dos genitores foram semeadas em vasos plásticos de 4L contendo a mistura de $1 / 4$ de substrato Bioplant ${ }^{\circledR}$ e $3 / 4$ de latossolo vermelho amarelo. A calagem e as adubações foram feitas para atender às necessidades e o acúmulo de nutrientes na planta, com adaptação para vaso (BATAGLIA et al., 1976). No momento da semeadura, as sementes 90 
foram tratadas com fungicida Carbendazim-Thiram 200 SC, posteriormente inoculadas com estirpes de Bradyrhizobium japonicum. Semanalmente, foram semeados dois vasos por cultivar afim de ampliar as possibilidades de coincidência na floração. A primeira etapa de cruzamentos iniciou-se em dezembro de 2011 e se estenderam até janeiro de 2012. A segunda etapa teve início em novembro de 2012 e estenderam-se até janeiro de 2013. A irrigação foi realizada manualmente, mantendo-se o substrato dos vasos na capacidade de campo.

Os cruzamentos foram concentrados no período de 8:00 às 11:00 horas, diariamente, após o aparecimento dos primeiros botões florais. Nas plantas receptoras de pólen foram escolhidos botões antes da antese, realizando-se emasculação com auxilio de uma pinça de relógio. As flores doadoras de pólen foram escolhidas nos genitores masculinos quando abertas e na antese, transferindo-se o pólen para o estigma da flor feminina, com auxílio da pinça. Cada botão hibridizado recebeu uma etiqueta com a identificação de seus progenitores.

\subsubsection{Geração $\mathbf{F}_{1}$}

As sementes oriundas dos cruzamentos deram origem à geração $\mathrm{F}_{1}$. Em maio de 2013, na Estação Experimental de Biologia da UnB, as sementes híbridas foram semeadas em canteiros com substrato à base de solo e matéria orgânica, com adubação para atender as exigências da planta (BATAGLIA et al., 1976). No momento da semeadura as sementes foram tratadas com fungicida Carbendazim-Thiram 200 SC, posteriormente inoculadas com estirpes de

Bradyrhizobium japonicum. As plantas híbridas foram identificadas pela coloração do hipocótilo, flor, pubescência. Os híbridos foram suplementados por iluminação artificial (temporizador analógico com lâmpadas incandescentes de 200 w), afim de, prolongar o fotoperíodo em 5:30 h 
(17:00 as 22:30). A irrigação foi realizada por aspersão. A colheita e beneficiamento dos grãos foram realizados individualmente por híbridos, entre setembro e outubro de 2013. As sementes foram identificadas e armazenadas em câmara fria a $10^{\circ} \mathrm{C}$.

\subsubsection{Geração $\mathbf{F}_{2}$}

O experimento foi conduzido na Fazenda Água Limpa, UnB - DF, latitude $15^{\circ} 56^{\prime} \mathrm{S}$, longitude $47^{\circ} 56^{\prime} \mathrm{W}$ e altitude média de $1.080 \mathrm{~m}$. Segundo Köeppen, o clima é do tipo Aw tropical chuvoso de inverno seco. O solo é classificado como Latossolo Vermelho-Amarelo - LVA, textura argilosa, fase Cerrado. O solo da área foi analisado quimicamente para recomendação de calagem e adubação, para atender as exigências da cultura.

A semeadura foi realizada em 30 de dezembro de 2013. O delineamento experimental adotado foi o de blocos casualizados com quatro repetições. Os tratamentos foram constituídos por 20 cruzamentos (Tabela 2). Cada parcela foi composta por uma linha com 2,5 $\mathrm{m}$ de comprimento, espaçadas entre si por $1,0 \mathrm{~m}$ e $0,10 \mathrm{~m}$ entre plantas (modificado de SPEHAR, 1998).

Realizaram-se aração e gradagens antecedendo à semeadura, precedida por inoculação e tratamento das sementes com estirpes de Bradyrhizobium japonicum na dose de $500 \mathrm{~g}$ de inoculante para $50 \mathrm{~kg}$ e fungicida Carbendazim-Thiram $200 \mathrm{SC}$, na dose de $200 \mathrm{~mL} / 100 \mathrm{~kg}$. A adubação foi realizada com base na análise de solo e nas recomendações para a cultura, correspondendo a $500 \mathrm{~kg} \mathrm{ha}^{-1}$ da formulação NPK 00-16-16. O controle das plantas daninhas foi feito por meio de capina manual. Para controle da ferrugem asiática (Phakopsora pachyrhizie) 
foram realizadas pulverizações 0,6 L.ha ${ }^{-1}$ do fungicida Opera® (Piraclostrobina e Epoxiconazol) com intervalos de 20 dias a partir do estádio R1 (FEHR; CAVINESS, 1977) das plantas de soja.

A colheita ocorreu a partir de abril de 2014, de acordo com a maturação (estádio R9). As plantas foram colhidas em conjunto de acordo com a maturação por parcela, posteriormente avaliadas e armazenadas individualmente.

\subsubsection{Avaliações}

As características agronômicas avaliadas foram: a) número de dias para maturação (NDM), período que correspondeu ao número de dias decorridos desde a emergência das plântulas até a data em que $95 \%$ das vagens das plantas da parcela apresentaram-se maduras; b) altura das plantas (AP), realizada na maturação medindo da base da planta até a inserção do rácemo no ápice da haste principal; c) altura de inserção da primeira vagem (AIV), realizada na maturação medindo a distância, a partir da superfície do solo até a primeira vagem da haste principal; d) número de vagens por plantas (NVP), média obtida por contagem direta de vagens por plantas; e) rendimento de grãos por planta (RG): determinado após a trilha das plantas e limpeza das sementes convertendo-os em g planta ${ }^{-1}$.

\subsubsection{Estatística}

Foi realizada análise de variância, com base na média de parcelas, em blocos ao acaso, visando avaliar a existência de variabilidade genética entre os tratamentos e estimação de parâmetros genéticos e não genéticos. Após a análise de variância os dados passaram por 
comparação das médias pelo teste de Scott Knott de todas as variáveis. A estimativa dos componentes da variância foi realizada pelo programa Genes (CRUZ, 1997). Foram estimados: variância genotípica entre médias; variância ambiental; herdabilidade no sentido amplo; coeficiente de variação genética; correlações fenotípicas; razão CVg/CVe, onde valores maiores que 1,0 (um) possibilitam uma seleção efetiva por métodos mais simples de melhoramento e favorecem a seleção fenotípica de caracteres (PIMENTEL-GOMES, 1985; CRUZ et al., 2004).

\subsection{RESULTADOS E DISCUSSÃO}

A partir da análise de variância foi possível verificar a diferença significativa entre os tratamentos, para todas as variáveis a $\mathrm{p}<0,01$, exceto para AIV que foi significativo a $\mathrm{p}<0,05$ (Tabela 3) pelo teste F.

Tabela 3. Resumo da análise de variância, de 20 cruzamentos de soja, geração $F_{2}$, utilizando dados de ensaio conduzido na Fazenda Água Limpa, Brasília, 2014.

\begin{tabular}{ccccccc}
\hline & & \multicolumn{5}{c}{ Quadrado médio } \\
\cline { 3 - 6 } FV & GL & NDM & AP & AIV & NVP & RG \\
\hline Blocos & 3 & 2118,51 & 407,02 & 12,21 & 1050,26 & 22,76 \\
Tratamentos & 19 & $181,30 * *$ & $269,83 * *$ & $5,09 *$ & $800,79 * *$ & $38,14 * *$ \\
Resíduos & 57 & 18,23 & 25,12 & 2,73 & 339,94 & 16,20 \\
\hline Média & 120,13 & 71,81 & 9,66 & 70,63 & 13,098 \\
\hline CV(\%) & 3,55 & 6,98 & 17,13 & 26,10 & 30,00 \\
\hline ** e * significativos a P < 0,01 e P < 0,05, respectivamente, pelo teste F. \\
$\begin{array}{l}\text { NDM: número de dias para a maturação; AP: altura das plantas; AIV: altura da inserção da } \\
\text { primeira vagem; NVP: número de vagens por plantas e RG: rendimento de sementes por planta. }\end{array}$
\end{tabular}


Estes resultados demonstram a diversidade entre os genótipos avaliados na geração $F_{2}$. Os coeficientes de variação para as características estudadas, de 3,55 a 30\%, confirmam o apresentado na literatura para a cultura da soja (LOPES et al., 2002; CARVALHO et al., 2009).

Os resultados médios das variáveis estudadas nas progênies dos 20 cruzamentos encontram-se na Tabela 4. Número de dias à maturação e altura de plantas possibilitou maior discriminação entre os tratamentos, ou seja, aqueles em que se obtiveram o maior número de grupos significativamente diferentes.

O NDM variou de 107 dias (BRS 257 x HCSI) a 132 dias (Conquista x UFVTN105), com uma oscilação de 25 dias no ciclo, evidenciando a variabilidade entre as progênies analisadas. $\mathrm{O}$ grupo mais precoce foi composto pelas progênies dos cruzamentos BRS 257 x UnB 1125, BRS 257 x A 7002 e BRS 257 x HCSI, que completaram o ciclo em média aos 109 DAE, comprovando assim, uma maior precocidade. $\mathrm{O}$ fator que, possivelmente, pode ter influenciado no ciclo dessas progênies foi a ausência de período juvenil longo (SPEHAR et al, 2014), uma vez que seus genitores, principalmente o feminino BRS 257, é recomendados para a região sul do país.

As maiores alturas de plantas foram observadas pelas progênies derivadas do cruzamento Amaralina x UFVTN105, com média de $87 \mathrm{~cm}$. No geral, para altura de plantas, foram englobadas no mesmo grupo as progênies oriundas dos cruzamentos Amaralina x UFVTN105, Conquista x UFVTN105, M 8585 x BRSMG 790A e BRS 257 x DM 309 com média de $83 \mathrm{~cm}$. Entretanto, as progênies inseridas nos cruzamentos pertencentes ao, segundo grupo, com melhor AP, também apresentaram altura satisfatória para cultivo comercial, com média superior a $70 \mathrm{~cm}$. Verificou-se ainda que os piores resultados foram obtidos pelas progênies referente aos cruzamentos BRS 257 x M 8867 e BRS 257 x HCSI com média de $56 \mathrm{~cm}$, no limite inferior ao 
recomendado para a colheita mecanizada (REZENDE; CARVALHO, 2007).

A AIV formou dois grupos significativos e variou entre valores máximo de 11,27 $\mathrm{cm} \mathrm{e}$ mínimo de 7,11 cm (Tabela 4).

Tabela 4. Médias de caracteres agronômicos de genótipos, geração $F_{2}$, provenientes de híbridos de soja para alimentação humana com período juvenil longo - FAL, Brasília - DF, $15^{\circ} 56^{\prime} \mathrm{S}$ e $47^{\circ} 06^{\prime} \mathrm{O}$, altitude $1100 \mathrm{~m}$.

\begin{tabular}{lllrrrc}
\hline & \multicolumn{1}{c}{ Genótipo } & NDM & $\begin{array}{c}\text { AP } \\
(\mathrm{cm})\end{array}$ & $\begin{array}{r}\text { AIV } \\
(\mathrm{cm})\end{array}$ & NVP & $\begin{array}{c}\text { RG } \\
(\text { g.planta }\end{array}$ \\
\hline 1 & Conquista x UFVTN105 & $132 \mathrm{a}$ & $82,59 \mathrm{a}$ & $10,72 \mathrm{a}$ & $52,34 \mathrm{~b}$ & $11,45 \mathrm{~b}$ \\
2 & Amaralina x UFVTN105 & $130 \mathrm{a}$ & $87,10 \mathrm{a}$ & $8,76 \mathrm{~b}$ & $69,87 \mathrm{~b}$ & $10,62 \mathrm{~b}$ \\
3 & M 8585 x BRSMG 790 & $129 \mathrm{a}$ & $81,89 \mathrm{a}$ & $10,37 \mathrm{a}$ & $70,05 \mathrm{~b}$ & $11,38 \mathrm{~b}$ \\
4 & UFVTN105 x M 9144 & $128 \mathrm{a}$ & $73,40 \mathrm{~b}$ & $9,95 \mathrm{a}$ & $82,12 \mathrm{a}$ & $15,74 \mathrm{a}$ \\
5 & M 9144 x UFVTN105 & $125 \mathrm{~b}$ & $74,77 \mathrm{~b}$ & $10,27 \mathrm{a}$ & $65,38 \mathrm{~b}$ & $10,85 \mathrm{~b}$ \\
6 & M 8585 x UFVTN105 & $122 \mathrm{~b}$ & $76,21 \mathrm{~b}$ & $9,61 \mathrm{a}$ & $55,88 \mathrm{~b}$ & $9,51 \mathrm{~b}$ \\
7 & M 8585 x BRS 257 & $122 \mathrm{~b}$ & $70,91 \mathrm{c}$ & $8,60 \mathrm{~b}$ & $68,10 \mathrm{~b}$ & $9,65 \mathrm{~b}$ \\
8 & M 8585 x BRSMG 800a & $121 \mathrm{~b}$ & $75,83 \mathrm{~b}$ & $10,71 \mathrm{a}$ & $65,10 \mathrm{~b}$ & $13,23 \mathrm{~b}$ \\
9 & UFVTN105 x M 8585 & $121 \mathrm{~b}$ & $71,61 \mathrm{c}$ & $11,27 \mathrm{a}$ & $57,74 \mathrm{~b}$ & $9,17 \mathrm{~b}$ \\
10 & BRS 257 x M 9144 & $121 \mathrm{~b}$ & $63,35 \mathrm{c}$ & $8,70 \mathrm{~b}$ & $91,52 \mathrm{a}$ & $17,24 \mathrm{a}$ \\
11 & BRSMG 800A x A 7002 & $121 \mathrm{~b}$ & $66,38 \mathrm{c}$ & $8,97 \mathrm{~b}$ & $98,75 \mathrm{a}$ & $17,03 \mathrm{a}$ \\
12 & UFVTN105 x M 8867 & $121 \mathrm{~b}$ & $70,54 \mathrm{c}$ & $8,94 \mathrm{~b}$ & $93,18 \mathrm{a}$ & $21,69 \mathrm{a}$ \\
13 & BRS 257 x Preta linhagem & $117 \mathrm{c}$ & $69,97 \mathrm{c}$ & $10,23 \mathrm{a}$ & $72,29 \mathrm{~b}$ & $12,98 \mathrm{~b}$ \\
14 & BRS 257 x DM 309 & $117 \mathrm{c}$ & $80,82 \mathrm{a}$ & $10,54 \mathrm{a}$ & $63,67 \mathrm{~b}$ & $12,15 \mathrm{~b}$ \\
15 & BRS 257 x CD 219 & $117 \mathrm{c}$ & $67,74 \mathrm{c}$ & $11,08 \mathrm{a}$ & $59,14 \mathrm{~b}$ & $12,49 \mathrm{~b}$ \\
16 & BRS 257 x M 8867 & $116 \mathrm{c}$ & $57,68 \mathrm{~d}$ & $7,84 \mathrm{~b}$ & $62,08 \mathrm{~b}$ & $10,91 \mathrm{~b}$ \\
17 & BRS 257 x Conquista & $115 \mathrm{c}$ & $65,91 \mathrm{c}$ & $9,01 \mathrm{~b}$ & $59,69 \mathrm{~b}$ & $14,10 \mathrm{~b}$ \\
18 & BRS 257 x UnB 1125 & $112 \mathrm{~d}$ & $76,09 \mathrm{~b}$ & $10,82 \mathrm{a}$ & $82,72 \mathrm{a}$ & $13,79 \mathrm{~b}$ \\
19 & BRS 257 x A 7002 & $109 \mathrm{~d}$ & $69,51 \mathrm{c}$ & $9,54 \mathrm{a}$ & $89,27 \mathrm{a}$ & $14,88 \mathrm{a}$ \\
20 & BRS 257 x HCSI & $107 \mathrm{~d}$ & $53,91 \mathrm{~d}$ & $7,11 \mathrm{~b}$ & $53,81 \mathrm{~b}$ & $13,04 \mathrm{~b}$ \\
\hline
\end{tabular}

Médias seguidas de mesma letra minúscula na coluna não diferem pelo teste de $\mathrm{Scott}$ Knott $(\mathrm{p} \leq$ $0,05)$.

NDM: número de dias para a maturação; AP: altura de planta; AIV: altura da primeira vagem; NVP: número de vagem por planta e RG: rendimento de grãos por planta. 
Foram formados dois grupos significativos para NVP, com valores oscilando entre 52,34 a 98,75 entre as progênies dos cruzamentos Conquista x UFVTN105 e BRSMG 800A x A 7002 respectivamente (Tabela 4), com uma média geral de 70,63 vagens por planta. O primeiro grupo foi composto por seis cruzamentos com valores médios de 89,60 que variaram de 82,12 a 98,75 vagens por plantas. O segundo grupo foi constituído por quatorze cruzamentos onde os valores oscilaram de 52,34 a 72,29 com média de 62,51. Vislumbra-se diferença de 30,23\% nos valores entre estes dois grupos. Esses resultados corroboram aos encontrados por Santos et al. (2011) que obtiveram uma média de 71,80 vagens por planta em 48 genótipos de soja analisados.

Para rendimento de grãos por planta, também foram formados dois grupos significativos, o primeiro composto por progênies de cinco cruzamentos e o segundo por quinze cruzamentos. $\mathrm{O}$ cruzamento que apresentou maior RG foi UFVTN105 x M 8867 com 21,69 g.planta ${ }^{-1}$ (Tabela 4). Em contrapartida o cruzamento que apresentou piores valores foi UFVTN105 x M 8585 com 9,17 g.planta ${ }^{-1}$. A diferença observada entre as progênies desses dois cruzamentos foi de $58 \%$. Os valores obtidos nesta pesquisa para RG divergem aos encontrados por Martins et al (2002).

O coeficiente de herdabilidade, como expressão quantitativa, reflete os valores de herança e do ambiente na expressão de caracteres de interesse. Quanto maior for esse coeficiente, maior será o sucesso da seleção para um dado caráter, resultando numa relação positiva entre alta herdabilidade e eficácia seletiva. O coeficiente de herdabilidade pode variar de 0 a 1 , quando o fenótipo é completamente determinado pelo genótipo, não tendo influência do ambiente; quando igual à zero, a variabilidade do caráter não tem origem genética. Valores maiores que 0,5 representam alta herdabilidade; valores compreendidos entre 0,2 e 0,5 e menores que 0,2 , respectivamente, representam coeficientes de herdabilidade médios e baixos (ALLARD, 1974; SILVEIRA et al., 2006). 
As estimativas de herdabilidade no sentido amplo, obtidas para as variáveis NDM e AP, foram altas e relativamente maiores do que aquelas obtidas para as características relacionadas com a produção, isto é, o NVP e RG (Tabela 5). Esses resultados estão de acordo com Oliveira et al. (2000) e Silveira et al. (2006).

Tabela 5. Estimativas das variâncias fenotípica $\left(V_{f}\right)$, genotípica $\left(V_{g}\right)$, ambiental $\left(V_{e}\right)$, herdabilidade senso amplo $\left(\mathrm{h}_{\mathrm{a}}{ }^{2}\right)$, coeficiente de variação genético $\left(\mathrm{CV}_{\mathrm{g}}\right)$ e razão entre coeficiente de variação genético e ambiental $\left(\mathrm{CV}_{\mathrm{g}} / \mathrm{CV}_{\mathrm{e}}\right)$, utilizando-se dados de ensaio conduzido na Fazenda Água Limpa - DF para características agronômicas. Brasília, 2014.

\begin{tabular}{lccccc}
\hline \multicolumn{1}{c}{ Variância Estimada } & $\mathrm{NDM}$ & $\mathrm{AP}$ & $\mathrm{AIV}$ & $\mathrm{NVP}$ & $\mathrm{RG}$ \\
\hline $\mathrm{V}_{\mathrm{f}}$ (média) & 45,33 & 67,46 & 1,27 & 200,19 & 9,54 \\
$\mathrm{~V}_{\mathrm{e}}$ (média) & 4,56 & 6,28 & 0,68 & 84,99 & 4,050 \\
$\mathrm{~V}_{\mathrm{g}}$ (média) & 40,77 & 61,17 & 0,59 & 115,21 & 5,49 \\
$\mathrm{~h}_{\mathrm{a}}^{2}$ (média) & 0,90 & 0,91 & 0,46 & 0,57 & 0,57 \\
$\mathrm{CV}_{\mathrm{g}}$ & 5,314 & 10,89 & 7,95 & 15,19 & 17,88 \\
$\mathrm{CV}_{\mathrm{g}} / \mathrm{CV}_{\mathrm{e}}$ & 1,49 & 1,56 & 0,46 & 0,58 & 0,58 \\
\hline
\end{tabular}

NDM: número de dias para a maturação; AP: altura de planta; AIV: altura da primeira vagem; NVP: número de vagem por planta e RG: rendimento de grãos por planta.

Número de dias para maturação apresentou alta herdabilidade de 0,90 . Isso explica o fato de oito das nove progênies envolvendo a cultivar BRS 257 nos cruzamentos como genitor feminino, terem ficado nos dois grupos que apresentaram menores NDM. Ressalta-se ainda que as progênies oriundas do cruzamento BRS 257 x HCSI, apresentaram o menor NDM isso, possivelmente, ocorreu pelo fato desses genitores serem adaptados a região de maior latitude. Em contrapartida, o grupo que apresentou maiores médias para ciclo, 130 dias da emergência à maturação fisiológica, foi composto por genitores que apresentaram maior adaptação ao ambiente de cultivo. 
A herdabilidade média para altura de plantas foi superior a 0,91 , corroborando com os resultados obtidos por Oliveira et al. (2000) com herdabilidade no sentido amplo para altura de plantas em $\mathrm{F}_{2}$ de 0,95 .

Os caracteres influenciados por poucos genes apresentam alta herdabilidade em gerações precoces, ocorrendo à fixação de tipos distintos em poucas gerações de autofecundação. Por isso, para esses caracteres, principalmente no que se refere ao NDM $\left(\mathrm{h}_{\mathrm{a}}{ }^{2}=0,90\right)$ que é influenciado por apenas dois genes de acordo com Bernard (1971), e AP $\left(\mathrm{h}_{\mathrm{a}}{ }^{2}=0,91\right)$ pode-se fazer seleção em gerações precoces, facilitando a condução do programa de melhoramento que objetivam incorporar essas características.

$\mathrm{O}$ quociente $\mathrm{CVg} / \mathrm{CV}$ e representa uma informação muito importante para o melhorista e, segundo Vencovsky e Barriga (1992), quando atinge o valor 1,0 ou mais, indica uma situação muito favorável para a seleção

Os coeficientes da relação $\mathrm{CVg} / \mathrm{CVe}$ apresentaram valores acima da unidade para as variáveis NDM $(1,49)$ e AP $(1,56)$ (Tabela 5) sendo estas favoráveis a seleção fenotípica, em gerações precoces. Caracteres que obtém valores maiores que 1 (um) possibilitam uma seleção efetiva por métodos mais simples de melhoramento como a massal. Resultados semelhantes para AP e AIV também foram obtidos por Finholdt (2012), onde os valores encontrados para AP foi de 1,29 .

A herdabilidade observada para AIV, NVP e RG foi de 0,46; 0,57 e 0,57 respectivamente (Tabela 5). E a razão CVg/CVe foi de 0,46 para AIV e 0,58 para NVP e RG sendo entretanto, abaixo de 1, isso reflete uma condição desfavorável a seleção, uma vez que a variância genética foi menor que a variância ambiental. De acordo com Alves (2004), valores desta magnitude indicam que o emprego de métodos simples de seleção, como massal, não proporcionariam 
ganhos expressivos durante o processo de seleção. $\mathrm{O}$ emprego de métodos baseados no desempenho de famílias é mais adequado do que aqueles que utilizam a seleção com base no desempenho individual de plantas.

Os valores mais baixos de herdabilidade encontrados para NVP, AIV e de RG por planta, na geração $\mathrm{F}_{2}$, indicam a alta influência de fatores ambientais sobre os mesmos (Tabela 5). Segundo Gilioli et al. (1980) a altura da primeira de inserção da vagem (AIV), parece ser uma herança quantitativa, sendo, portanto, muito afetado pelo ambiente. Ainda neste trabalho os autores verificaram que os valores encontrados para essa variável nas plantas $F_{2}$ de soja foram inferiores aos genitores. Os caráteres NV e RG são de natureza poligênica (quantitativa), controlado por muitos genes, e sofrem maiores influência ambiental. Por isso, as estimativas de herdabilidade são menores em comparação aos demais caracteres agronômicos (MUNIZ, 2007).

As estimativas de herdabilidade no sentido amplo obtidas para NVP e RG por planta na geração $F_{2}$ foram relativamente baixas, e estão de acordo com os resultados de Oliveira et al. (2000) ao avaliar progênies de soja $F_{2}$ em campo e Costa et al. (2008) que encontrou valores baixo para herdabilidade para a maioria das famílias dos cruzamentos obtidos na geração $\mathrm{F}_{3}$ de soja. Assim a seleção para essas variáveis pode ser ineficiente nas primeiras gerações.

A correlação é um parâmetro importante nos programas de melhoramento genético, por indicar a influencia que um caráter pode ter sobre outro, explicando o grau de associação de duas variáveis. Assim, a variação de uma característica acompanha a variação da outra (RAMALHO, 2004; VILELA, 2008).

Os coeficientes de correlação (r) podem ser classificados em função da magnitude dos seus

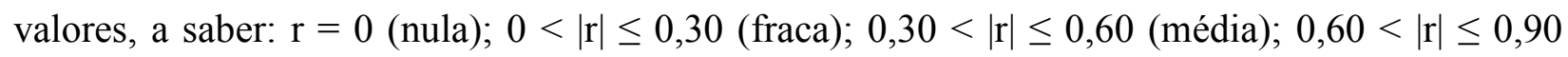
(forte); $0,90<|\mathrm{r}| \leq 1$ (fortíssima) e $|\mathrm{r}|=1$ (perfeita) (CARVALHO et al., 2004). 
Com a correlação entre caracteres é possível fazer seleção indireta para um caráter desejado. Muitas vezes pode-se obter progresso mais rápido do que na seleção direta. Entretanto, quando duas características são correlacionadas positivamente e com alto grau de associação, sendo uma delas indesejável, o melhorista encontra dificuldades. Isso também ocorre quando as duas características são desejáveis, mas apresentam correlações negativas com alto valor (FALCONER, 1981).

Os dados referentes às correlações fenotípicas encontram-se na Tabela 6. Foram obtidas correlações positivas e significativas a ( $p<0,01)$, entre as variáveis NDM x AP, AP x AIV, NV x RG. As correlações entre as variáveis NDM x AP e NV x RG apresentaram magnitude forte de 0,687 e 0,777 respectivamente. E magnitude mediana para a correlação entre AP x AIV. Corroborando com Silva et al. (2015) que também obtiveram correlação positiva e significativa de magnitude media entre AP x AIV.

Tabela 6. Estimativas de valores de correlação fenotípica entre características de progênies $F_{2}$ de soja oriundas de 20 cruzamentos. Fazenda Água Limpa. Brasília, 2014.

\begin{tabular}{cccccc}
\hline & NDM & AP & AIV & NVP & RG \\
\hline NDM & 1 & $0,687^{* *}$ & 0,301 & $-0,059$ & $-0,188$ \\
AP & - & 1 & $0,598^{* *}$ & $-0,079$ & $-0,280$ \\
AIV & - & - & 1 & $-0,134$ & $-0,211$ \\
NVP & - & - & - & 1 & $0,777^{* *}$ \\
RG & - & - & - & - & 1 \\
\hline ** significativos a p $<0,01$ pelo teste F. & & &
\end{tabular}

NDM: número de dias para a maturação; AP: altura de planta; AIV: altura da primeira vagem; NVP: número de vagem por planta e RG: rendimento de grãos por planta. 
Observou-se uma relação direta para NVP e RG, quanto maior a produção de vagem maior o RG, exceto as progênies do cruzamento BRS 257 x UnB 1125 que não acompanharam a mesma tendência (Tabela 4). Essa constatação foi confirmada pela estimativa de correlação (Tabela 6) onde o valor foi significativo $(0,77)$ apresentando, entretanto forte magnitude (SILVA et al., 2015).

O que contribuiu para esse resultado foi que as plantas mais precoces e com menor altura produziram, proporcionalmente, maior quantidade de vagens e consequentemente maior RG. Plantas de soja apresentam alta plasticidade, ou seja, capacidade de se adaptar às condições ambientais e de manejo, por meio de modificações na morfologia e nos componentes do rendimento (TAVARES et al., 2013). A forma com que tais modificações ocorrem pode esta relacionada a fatores como altitude, latitude, fertilidade do solo, época de semeadura, população de plantas e espaçamento entre linhas, sendo importante o conhecimento das interações entre estes, para definição do conjunto de práticas favoráveis ao rendimento agrícola da lavoura (HEIFFIG, 2002).

Assim, o fator que, possivelmente, influenciou nos resultados, deste trabalho, foi o espaçamento adotado nas parcelas. Progênies com menor ciclo e altura de plantas apresentaram uma quantidade maior de ramificações, o que ocasionou em maiores valores para os componentes produtivos, como NVP e RG.

\subsection{CONCLUSÕES}

A hibridação entre cultivares com período juvenil longo e de cultivares com ausência de lipoxigenase origina grande variação no número de dias para a maturação em soja. 
O cruzamento Amaralina x UFVTN105 apresenta maior probabilidade de selecionar para altura de plantas, enquanto o cruzamento UFVTN105 x M 8867 apresenta maior frequência de recombinantes com produtividade.

A seleção por número de dias para a maturação e altura de plantas é efetiva na geração $\mathrm{F}_{2}$ para se obter soja sem lipoxigenase, com base no quociente $\mathrm{CVg}$ / CVe.

Correlações positivas e significativas de magnitude forte entre as variáveis NDM x AP e NV x RG e de magnitude mediana entre AP x AIV, indicam a possibilidade de ganho por seleção para soja produtiva e sem lipoxigenase.

\title{
2.5 REFERÊNCIAS
}

\author{
ALVES, J. C. S. Estimativa de parâmetros genéticos para caracteres de semente e de planta \\ em populações de cenoura (Daucus carota L.) derivadas da cultivar Brasília. Brasília: \\ Universidade de Brasília, 2004. 68 p. Dissertação Mestrado.
}

ALLARD, R. W. Princípios do melhoramento genético das plantas. Rio de Janeiro: Usaid, Edgard Blucher, 1974. 381p.

BAtAGliA, O. C.; MASCARENHAS, H. A. A.; TEIXEIRA, J. P. F.; TISSELI FILHO, O. Acúmulo de matéria seca e nutrientes, em soja cultivar Santa-Rosa. Bragantia, v. 35, n. 21, p. 237-247, 1976. 
BERNARD, R.L. Two major genes for time of flowering and maturity in soybeans. Crop Sci., v. 11, p. 242-244, 1971.

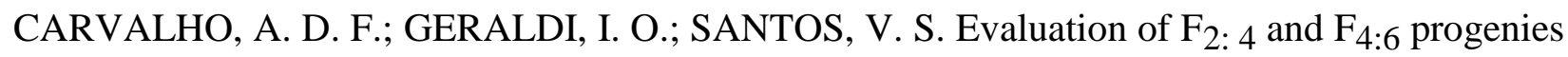
of soybeans and perspectives of using early generation testing for grain yield. Bragantia, v. 68, n. 4, p. 857-861, 2009.

CARVALHO, F. I. F.; LORENCETTI, C.; BENIN, G. Estimativas e implicações da correlação no melhoramento vegetal. Pelotas: Ed. Universitária da UFPel, 2004. 142 p.

COSTA, M. M.; DI MAURO, A. O.; UNÊDATREVISOlI, S. H.; ARRIEL, N. H. C.; BÁRbARO, I. M.; SILVEIRA, G. D.; MUNIZ, F. R. S. Heritability estimation in early generations of two-way crosses in soybean. Bragantia, v. 67, n. 1, p. 101-108, 2008.

CRUZ, C. D.; REGAZZI, A. J.; CARNEIRO, P. C. S. Modelos biométricos aplicados ao melhoramento genético. 3. ed. Viçosa: UFV, 480 p, 2004.

CRUZ, C. D. Programa Genes: aplicativo computacional em genética e estatística. Viçosa: Editora UFV, 1997. 442 p.

DeStro, D.; SediYAmA, T.; SILVA, J. C.; SediyAMA, C. S.; ThiÉBAUT, J. T. L. Estimativas de herdabilidade de alguns caracteres em dois cruzamentos de soja. Pesquisa Agropecuária Brasileira, v. 22, n. 3, p. 291-304, 1987. 
FALCONER, D. S. Introdução à genética quantitativa. Viçosa MG: UFV, 1981. 279 p.

FEHR, W. R. \& CAVINESS, C. E. Stages of soybean development. Iowa State University. 12p (Special Report, 80), 1977.

FIETZ, C. R.; RANGEL, M. A. S. Época de semeadura de soja para região de Dourados - MS, com base na deficiência hídrica e no fotoperíodo. Engenharia Agrícola, v. 28, n. 4, p. 666-672, 2008.

FINHOLDT, R. S. Estimativas do coeficiente de herdabilidade entre e dentro de famílias $\mathbf{f}_{5}$ de soja. Jaboticabal, 2012. 53 p. Dissertação Mestrado.

GILIOLI, J. L.; SEDIVAMA, S.; SILVA, J. C.; THIÉBAUT, J. T. L.; REIS, M. S. Estimativas de herdabilidade e de correlações fenotípicas para alguns caracteres, em quatro mutantes naturais em soja. Pesquisa Agropecuária Brasileira, n. 15, v. 4, p. 379-384, 1980.

HEIFFIG, L. S. Plasticidade da cultura da soja (Glycine max (L) Merrill) em diferentes arranjos espaciais. Piracicaba: Universidade de São Paulo, 2002. Dissertação Mestrado.

LOPES, A. C. A.; VEllo, N. A.; PANDINI, F.; ROCHA, M. M.; TSUTSUMI, C. Y. Variabilidade e correlações entre caracteres em cruzamentos de soja. Scientia Agricola, v. 59, n. 2, p. 341-348, 2002. 
MARTINS, C. A. O.; SEDIYAMA, C. S; MOREIRA, M. A.; REIS, M. S.; ROCHA, V. S.; OLIVEIRA, M. G. A. Efeito da eliminação genética das lipoxigenases sobre as características agronômicas da soja. Pesquisa Agropecuária Brasileira, v. 37, n.10, p. 1389-1398, 2002.

MUNIZ, F. R. S. Análise da variabilidade genética em populações segregantes de soja. Jaboticabal: Universidade Estadual Paulista, 2007. p. 94. Tese Doutorado.

OLIVEIRA, A. C. B.; VIANA, J. M. S.; CRUZ, C. D.; SEDIYAMA, C. S. Herdabilidade e correlações em plantas $F_{2}$ de soja cultivadas em diferentes condições ambientais. Acta Scientiarum, v. 22, p. 889- 893, 2000.

PIMENTEL-GOMES, F. Curso de estatística experimental. São Paulo: Esalq, 1985. 467 p.

RAMAlHO, M. A. P. SANTOS, J. B., PINTO, C. A. B. P. Genética na agropecuária. 3 ed. rev., Lavras: UFLA, 2004. 472 p.

REZENDE, P.M.; CARVALHO, E. A. Avaliação de cultivares de soja Glycine max (L.) Merrill para o sul de Minas Gerais. Ciência e Agrotecnologia, v.31, n.6, p.1616-1623, 2007.

SANTOS, E. R.; BARROS, H. B.; FERRAZ, E. C.; CELlA, A. J. S.; CAPONE, A.; SANTOS, A. F.; FIDELIS, R. R. Divergência entre genótipos de soja, cultivados em várzea irrigada. Rev. Ceres, v. 58, n.6, p. 755-764, 2011. 
SILVA, S. S. B.; AZEVEDO, C. V. G.; OLIVEIRA, M. P.; TEIXEIRA, L. C. A. A.; JUHASZ, A. C. P.; UNÊDA-TREVISOLI, S. H. Correlações fenotipicas entre componentes de produção em linhagens F3 de soja. Ciência \& Tecnologia, v. 7, número especial, 2015.

SILVEIRA, G. D.; MAURO, A. O. D.; CENTURION, M. A. P. C. Seleção de genótipos de soja para a região de Jaboticabal - Ano agrícola 2003-2004. Científica, v.34, n.1, p. 92-98, 2006.

SPEHAR, C. R., FRANCISCO, E. R.; PEREIRA, E. A. Yield stability of soybean cultivars in crop seasons and sowing dates at low latitude Brazilian Savannah Highlands. Journal of Agricultural Science, v. 153, p. 1059-1068, 2014.

SPEHAR, C. R. Comparison between hill and row plots methods on selection of soybeans for aluminium tolerance in a Brazilian savannah (Cerrado) acid soil. Pesquisa Agropecuária Brasileira, v. 33, n. 6, p. 899-904,1998.

ST MARTIN, S. K.; XIE, F.; ZHANG, H.; ZHANG, W.; SONG, X. Epistasis for quantitative traits in crosses between soybean lines from China and the United States. Crop Science, v. 49, p. 20-28, 2009.

ST MARTIN, S. K.; GERALDI, I. O. Comparison of Three Procedures for Early Generation Testing of Soybean. Crop Science, v. 42, p.705-709, 2002. 
TAVARES, L. C.; RUFINO, C. A.; BRUNeS, A. P.; TUNES, L. M.; BARROS, A. C. S. A.; PESKE, S. T. Desempenho de sementes de soja sob deficiência hídrica: rendimento e qualidade fisiológica da geração F . Cienc. Rural, v. 43, n. 8, p. 1357-1363, 2013.

TSUKAMOTO, C; KUDOU, S.; KIKUCHI, A.; CARRÃO-PANIZZI, M. C.; ONO, T.; KITAMURA, K. K. (2001) Isoflavones in soybean products: composition, concentration and physiological effects. In: I Simpósio Brasileiro sobre os Benefícios da Soja para a Saúde Humana, Anais, Embrapa Soja. p. 9-14.

VASCONCELOS, E. S; REIS, M. S.; SEDIYAMA, T.; CRUZ, C. D. Produtividade de grãos, adaptabilidade e estabilidade de genótipos de soja de ciclos precoce e médio. Semina, v. 36, n. 3, p. 1203-1214, 2015.

VILELA, M. S. Estimativas de parâmetros genéticos para caracteres de cenoura em sistemas de cultivo agroecológico. Brasília: Brasília: Universidade de Brasília, 2008. 68 p.

Dissertação Mestrado.

VENCOVSKY, R.; BARRIGA, P. Genética biométrica no fitomelhoramento. Ribeirão Preto: Sociedade Brasileira de Genética, 1992. 469 p. 
CAPÍTULO 3. DESENVOLVIMENTO DE GENÓTIPOS DE SOJA COM AUSÊNCIA DE LIPOXIGENASES PARA CULTIVO EM BAIXAS LATITUDES

$\begin{array}{lllll}\text { CHAPTER } & 3 . & \text { SOYBEAN GENOTYPES DEVELOPMENT FREE }\end{array}$ LIPOXYGENASE TO GROWING IN LOW LATITUDES 


\section{RESUMO}

A inativação genética das enzimas lipoxigenases permite contornar problemas associados ao sabor indesejável das sementes da soja. Diante disso, objetivou-se com este trabalho avaliar características agronômicas de híbridos de soja, na geração $\mathrm{F}_{2}$, entre genitores sem lipoxigenase e com período juvenil longo, bem como identificar progênies sem lipoxigenases associadas a período juvenil longo. A pesquisa foi conduzida na Fazenda Água Limpa, UnB - DF, em 20132014, estudando-se 12 cruzamentos e 10 genitores com juvenilidade longa. O delineamento experimental foi de blocos casualizados com quatro repetições. A parcela foi constituída por uma linha com 2,5 m, espaçada por $100 \mathrm{~cm}$; foram avaliadas as características agronômicas: número de dias para maturação, altura das plantas, altura de inserção da primeira vagem, número de vagens por plantas e rendimento de grãos por planta. $\mathrm{O}$ teste colorimétrico para determinação da atividade de lipoxigenases foi baseado na descoloração das enzimas lipoxigenases (Lox) sobre o substrato ácido linoléico e co-oxidação com o azul de metileno (Lox -1 e Lox-2) e $\beta$-caroteno (Lox-3). As progênies com ciclo mais longo foram originadas do cruzamento M $8585 \mathrm{x}$ UFVTN105. O cruzamento Amaralina x UFVTN105 apresentou o maior número de progênies TN e com maior altura de planta. No total 35 progênies apresentaram ausência de lipoxigenases com período juvenil longo, com probabilidade de adaptação às baixas latitudes da região do Cerrado.

Palavras-chave: Glycine max, progênie, colorimetria, soja tipo alimento, período juvenil longo, seleção. 


\begin{abstract}
The elimination of lipoxygenase allows circumventing problems associated with undesirable beany flavor of soybean grains. In view of this, the work aimed at evaluating agronomic characteristics of soybean hybrids between lipoxygenase free and long juvenile period parents in generation $\mathrm{F}_{2}$, to recover recombinants in progenies associating the two characters. The experiment was conducted at Água Limpa Farm, University of Brasília, Brazil in 2013-2014 to study 12 hybrids and 10 parental accessions. The experimental design was a complete randomized block with four repetitions. The plot consisted of a $2.5 \mathrm{~m}$ long single row, spaced by $0.5 \mathrm{~m}$; the blocs were distant from the others by $1.0 \mathrm{~m}$. The following characteristics were evaluated: number of days to maturity, plant height, first pod height, number of pods per plant, and grain yield per plant. The colorimetric test to determine the lipoxygenase (Lox) enxyme activity was based on coloring of Lox enxymes over linoleic acid substrate and co-oxidation with methylene blue (Lox-1 e Lox-2) and $\beta$-carotene (Lox-3). The progenies with longer maturity period originate from M 8585 x UFVTN105 cross. The Amaralina x UFVTN 105 cross had the largest number of progenies combining lipoxygenase free, long juvenile period. In total, 35 progenies show the desirable combination with potential adaptability to the low latitudes of Brazilian Savannah.
\end{abstract}

Key Words: Glycine max, progeny, colorimetry, food type soybean, long juvenile period, selection. 


\subsection{INTRODUÇÃO}

A cultura da soja Glycine max (L.) é de grande importância econômica para o Brasil. Tem se destacado no agronegócio pelo aumento do interesse dos produtores, pelo aumento da demanda e do preço do grão no mercado mundial. O cultivo em $31,510^{6}$ ha com elevado rendimento se deve às mudanças ocorridas nos últimos 30 anos, com maior utilização de produtos e insumos agrícolas e obtenção de cultivares adaptadas às baixas latitudes, incorporando áreas inexploradas do Cerrado (FARINHA et al., 2009).

A soja é uma importante alternativa alimentar na nutrição humana, apresentando alto teor e qualidade proteica, lipídios, teores consideráveis de vitaminas do complexo B, fibras alimentares, oligossacarídeos com potencial prebiótico como rafinose e estaquiose, vitaminas e minerais. Ademais, contribui com outros benefícios à saúde humana, na prevenção e tratamento de doenças cardiovasculares, câncer, osteoporose e sintomas da menopausa (DANTAS et al., 2010).

Da soja produzida no Brasil, a maior parte é exportada para uso em ração animal (KINOUCHI et al., 2002; DANTAS et al., 2010). Entretanto, seu consumo entre os brasileiros como componente da alimentação tem aumentado passando de 3\% de grãos para $6 \%$ em 2006, por divulgação dos seus benefícios a saúde e também pelo crescimento de produtos à base de soja de melhor qualidade no mercado (CARRÃO-PANIZZI, 2000; EMBRAPA, 2011).

A soja ainda é pouco usada no consumo humano devido ao seu sabor desagradável conhecido como "beany flavor" atribuído pelas enzimas lipoxigenases (TSUKAMOTO et al., 2001) . As lipoxigenases são dioxigenases que contêm um átomo de ferro associado às suas estruturas, sendo responsáveis por catalisarem a adição do oxigênio molecular ao sistema 
pentadieno dos ácidos graxos polinsaturados, formando compostos voláteis de cadeias curtas como aldeídos e cetonas, responsáveis pelos sabores indesejáveis (SILVA et al., 2009).

As lipoxigenases são codificadas por três genes e apresenta herança mendeliana simples, os alelos que determinam a ausência dessas isoenzimas são recessivos. Os locos que controlam a Lox-1 e 2 estão ligados e o loco que controla Lox-3 apresenta segregação independente (KITAMURA et al., 1983). A inativação genética das lipoxigenases é a forma mais eficiente de reduzir o "beany flavor", pois o tratamento térmico prejudica sensivelmente às proteínas presentes nos grãos (MONTEIRO et al., 2004).

Alguns programas de melhoramento desenvolveram cultivares especiais, sem lipoxigenases, visando alimentos mais aceitáveis pelos consumidores brasileiros (CARRÃOPANIZZI, 2000; AZEVEDO et al., 2004). Contudo, a cultivar Conquista (que não apresenta características especiais a alimentação humana) ainda é a mais usada na indústria de alimentos (AGROLINK, 2012). Possivelmente, por existirem poucas cultivares destinadas ao consumo humano, adaptadas as diversas áreas de cultivo do Brasil, principalmente em baixas latitudes, limitando a expansão do cultivo. Cultivares sem lipoxigenase existentes, quando introduzidas em menores latitudes, apresentam baixo rendimento (SANTOS et al., 2011).

O desenvolvimento de genótipos de soja com características mais adequadas ao uso como alimento pode viabilizar o aumento de consumo e aumentar o valor agregado ao grão (CARRÃOPANIZZI; SILVA, 2011). Amplia as alternativas de mercado interno e externo para produtores e processadores podendo atender o mercado de soja orgânica, com cultivares de soja especial.

Parte considerável da área mundial cultivada com soja está localizada em latitudes maiores que $30^{\circ}$, onde prevalecem condições de clima temperado. O Brasil representa uma exceção dentro desse contexto, pois cerca de metade da produção brasileira é colhida em latitudes menores que 
$20^{\circ}$ (ROCHA et al., 2012). O desenvolvimento da soja é influenciado por vários fatores ambientais, entre estes a temperatura, a precipitação pluvial, a umidade relativa do ar, a umidade do solo e, principalmente, o fotoperíodo. A época de semeadura exerce influência decisiva sobre a quantidade e a qualidade da produção (MOTTA et al., 2000)

A expansão da soja em baixas latitudes tornou-se possível com o lançamento de cultivares com características agronômicas de melhor adaptação às condições edafoclimáticas dos trópicos e período juvenil longo (PJL). O PLJ estende a fase vegetativa da soja, elevando o crescimento da planta e a produtividade (SPEHAR et al., 2014). Assim pesquisas que visam criar, identificar genótipos mais adaptadas são de fundamental importância na otimização do sistema produtivo da soja e expansão de cultivo nas regiões de baixa latitude (ROCHA et al., 2012).

Pesquisas voltadas para aquisição de cultivares de soja do tipo alimento, livre de lipoxigenase, tornam-se necessárias para ampliar a área de cultivo nessas regiões de menores latitudes. Nesse sentido, objetivou-se avaliar os componentes agronômicos de cruzamentos de soja, na geração $F_{2}$, entre genitores sem lipoxigenase e genitores com período juvenil longo, visando selecionar recombinantes que reúnem as duas características.

\subsection{MATERIAL E MÉTODOS}

Os cruzamentos foram realizados na Estação Experimental de Biologia da Universidade de Brasília. Os genitores utilizados nos cruzamentos encontram-se na Tabela 1. Os 12 cruzamentos efetivos encontram-se na Tabela 2. 
Tabela 1. Genitores de soja utilizados nos cruzamentos. Origem da instituição.

\begin{tabular}{|c|c|c|c|}
\hline Genótipo & Instituição & Genótipo & Instituição \\
\hline $1-\operatorname{BRS} 257^{1}$ & EMBRAPA & 6- BRSGO Amaralina & EMBRAPA \\
\hline 2- UFVTN105 ${ }^{1}$ & UFV & 7- M $8867^{2}$ & Monsoy \\
\hline 3- M $9144^{2}$ & Monsoy & 8- A $7002^{2}$ & Nidera \\
\hline $4-\mathrm{M} 8585^{2}$ & Monsoy & 9- $\mathrm{CD} 219^{2}$ & Coodetec \\
\hline 5- Conquista ${ }^{2}$ & EMBRAPA & 10- DM $309^{2}$ & Agrop. Dois Marcos \\
\hline
\end{tabular}

Tabela 2. Doze cruzamentos, com seus genitores femininos (GF) e masculinos (GM).

\begin{tabular}{ccllll}
\hline \multicolumn{1}{c}{ GF } & & \multicolumn{1}{c}{ GM } & \multicolumn{1}{c}{ GF } & \multicolumn{1}{c}{ GM } \\
\hline 1- BRS 257(TN) & x & CD 219 (PJL) & 7- UFVTN105 (TN) & x & M 9144 (PJL) \\
2- BRS 257(TN) & x & DM 309 (PJL) & 8- M 8585 (PJL) & x & UFVTN105 (TN) \\
3- BRS 257(TN) & x & M 8867 (PJL) & 9- UFVTN105 (TN) & x & M 8867 (PJL) \\
4- BRS 257(TN) & x & M 9144 (PJL) & 10- M 8585 (PJL) & x & BRS 257 (TN) \\
5- BRS 257(TN) & x & A 7002 (PJL) & 11- Amaralina (PJL) & x & UFVTN105 (TN) \\
6- BRS 257(TN) & x & Conquista (PJL) & 12- Conquista (PJL) & x & UFVTN105 (TN) \\
\hline
\end{tabular}

TN: Triplo nulo (ausência de lipoxigenases).

Nas hibridações utilizaram-se como genitores oito cultivares de soja que apresentam PJL. A seleção foi baseada no desempenho agronômico na região dos Cerrados. Também empregou duas cultivares destinados à alimentação humana, ambas com ausência completa das enzimas lipoxigenases (TN). Os cruzamentos realizados envolveram um genitor com PJL e um genitor TN. 
Buscou-se, quando possível utilizar marcadores morfológicos recessivos no momento de decidir o genitor feminino, a fim de identificar precocemente o sucesso da hibridação. Observouse principalmente cor da flor e da pubescência, onde o genitor feminino foi prioritariamente portador de alelos recessivos (flor branca e pubescência cinza).

Os cruzamentos foram realizados em casa de vegetação na Estação Experimental de Biologia da UnB. As sementes dos genitores foram semeadas em vasos plásticos de 4L contendo a mistura de $1 / 4$ de substrato Bioplant ${ }^{\circledR}$ e $3 / 4$ de latossolo vermelho amarelo. A calagem e as adubações foram feitas para atender às necessidades e o acúmulo de nutrientes na planta, com adaptação para vaso (BATAGLIA et al., 1976). No momento da semeadura, as sementes foram tratadas com fungicida Carbendazim-Thiram 200 SC, posteriormente inoculadas com estirpes de Bradyrhizobium japonicum. Semanalmente, foram semeados dois vasos por cultivar afim de ampliar as possibilidades de coincidência na floração. A primeira etapa de cruzamentos iniciouse em dezembro de 2011 e se estenderam até janeiro de 2012. A segunda etapa teve início em novembro de 2012 e estenderam-se até janeiro de 2013. A irrigação foi realizada manualmente, mantendo-se o substrato dos vasos na capacidade de campo.

Os cruzamentos foram concentrados no período de 8:00 às 11:00 horas, diariamente, após o aparecimento dos primeiros botões florais. Nas plantas receptoras de pólen foram escolhidos botões antes da antese, realizando-se emasculação com auxilio de uma pinça de relógio. As flores doadoras de pólen foram escolhidas nos genitores masculinos quando abertas e na antese, transferindo-se o pólen para o estigma da flor feminina, com auxílio da pinça. Cada botão hibridizado recebeu uma etiqueta com a identificação de seus progenitores.

As sementes oriundas dos cruzamentos deram origem à geração $\mathrm{F}_{1}$. Em maio de 2013, na Estação Experimental de Biologia da UnB, as sementes híbridas foram semeadas em canteiros 
com substrato à base de solo e matéria orgânica, com adubação para atender as exigências da planta (BATAGLIA et al., 1976). No momento da semeadura as sementes foram tratadas com fungicida Carbendazim-Thiram 200 SC, posteriormente inoculadas com estirpes de

Bradyrhizobium japonicum. As plantas híbridas foram identificadas pela coloração do hipocótilo, flor, pubescência. Os híbridos foram suplementados por iluminação artificial (temporizador analógico com lâmpadas incandescentes de $200 \mathrm{w}$ ), afim de, prolongar o fotoperíodo em 5:30 h (17:00 as 22:30). A irrigação foi realizada por aspersão. A colheita e beneficiamento dos grãos foram realizados individualmente por híbridos, entre setembro e outubro de 2013. As sementes foram identificadas e armazenadas em câmara fria a $10^{\circ} \mathrm{C}$.

O experimento foi conduzido na Fazenda Água Limpa, UnB - DF, latitude $15^{\circ} 56^{\prime}$ S, longitude $47^{\circ} 56^{\prime} \mathrm{W}$ e altitude média de $1.080 \mathrm{~m}$. Segundo Köeppen, o clima é do tipo Aw tropical chuvoso de inverno seco. O solo é classificado como Latossolo Vermelho-Amarelo - LVA, textura argilosa, fase Cerrado. O solo da área foi analisado quimicamente para recomendação de calagem e adubação, para atender as exigências da planta (BATAGLIA et al., 1976).

O experimento foi implantado em 30 de dezembro de 2013. O delineamento experimental adotado foi o de blocos casualizados com quatro repetições. Foram constituídos 22 tratamentos compostos por 12 híbridos e 10 cultivares usados como genitores (Tabela 1 e Tabela 2). Dos híbridos foram obtidas 1115 progênies $F_{2}$. Cada parcela foi composta por uma linha de 2,5 m de comprimento, espaçadas entre si por $100 \mathrm{~cm}$ e 0,10 cm entre plantas, adaptado de Spehar (1998).

O solo foi preparado com aração e gradagem. No momento da semeadura, inocularam-se as sementes com estirpes de Bradyrhizobium japonicum, na dose de $500 \mathrm{~g}$ de inoculante para $500 \mathrm{~kg}$ de sementes, e com fungicida Carbendazim-Thiram 200 SC, na dose de $200 \mathrm{~mL} / 100 \mathrm{~kg}$ de semente. A adubação de semeadura foi realizada com base na análise de solo e nas 
recomendações para a cultura, correspondendo a $500 \mathrm{~kg} \mathrm{ha}^{-1}$ da formulação NPK 00-16-16. O controle de plantas daninhas foi feito por meio de capina manual. Para controle da ferrugem asiática (Phakopsora pachyrhizi) foram realizadas pulverizações com 0,6 L.ha ${ }^{-1}$ do fungicida Opera® (Piraclostrobina e Epoxiconazol) com intervalos de 20 dias a partir do estádio $\mathrm{R}_{1}$

(FEHR; CAVINESS, 1977) das plantas de soja, conforme recomendação do fabricante.

A colheita ocorreu a partir de abril de 2014, de acordo com a maturação (estádio R9). As plantas foram colhidas em conjunto de acordo com a maturação por parcela, posteriormente avaliadas e armazenadas individualmente.

As características agronômicas avaliadas foram: a) número de dias para maturação (NDM), período que correspondeu ao número de dias decorridos desde a emergência das plântulas até a data em que $95 \%$ das vagens das plantas da parcela apresentaram-se maduras; b) altura das plantas (AP), realizada na maturação medindo da base da planta até a inserção do racimo no ápice da haste principal, com auxilio de uma régua graduada; c) altura de inserção da primeira vagem (AIV), realizada na maturação medindo a distância, a partir da superfície do solo até a primeira vagem da haste principal, com auxilio de uma régua graduada; d) número de vagens por plantas (NVP), média obtida por contagem direta de vagens por plantas; e) rendimento de grãos por planta $(\mathrm{RG})$ foi determinado após a trilha das vagens e limpeza das sementes, a pesagem foi realizada em balança analítica, com precisão de 0,001 e os valores expressos em g planta $^{-1}$.

Os dados foram submetidos à análise de variância e ao teste $\mathrm{F}$, visando avaliar a existência de variabilidade genética entre os tratamentos. Quando constatado efeito significativo entre tratamentos, os dados foram comparados e as médias agrupadas pelo teste de Scott Knott a $\mathrm{P} \leq$ 0,05 de significância pelo programa estatístico SISVAR. 
Foram realizadas seleções nas progênies $F_{2}$ obtidas nos 12 cruzamentos (Tabela 2), tendo como critério a altura de plantas. Foram selecionados genótipos que apresentaram altura de plantas igual ou superior a $70 \mathrm{~cm}$ para serem avaliados individualmente para presença de lipoxigenases, empregado o método qualitativo de calorimetria, com o objetivo de selecionar as progênies com ausência completa das enzimas lipoxigenases e que apresentam período juvenil longo (PJL). Diante dessa seleção, foram analisados em laboratório 528 progênies $F_{2}$.

O teste bioquímico colorimétrico foi usado para determinar a atividade das enzimas lipoxigenases de acordo com Suda et al. (1995) e Kikuchi; Carrão-Panizzi (2001) baseado na atividade de descoramento das isoenzimas Lox sobre o substrato ácido linoléico e co-oxidação com o azul de metileno (Lox-1 e Lox-2) e $\beta$-caroteno (Lox-3), a partir de produtos formados pela reação enzima-substrato com formação de radicais peroxil que interagem com os indicadores azul de metileno e $\beta$-caroteno ocorrendo descoramento.

\subsubsection{Método Colorimétrico - Determinação da presença/ausência da lipoxigenase}

Essa etapa foi realizada no Laboratório de Análise de Alimentos - UnB, no período de 16 de dezembro de 2015 a 20 de fevereiro de 2016.

\subsubsection{Preparo das Amostras de Soja}

Triturou-se até ao ponto de farinha, um grão de soja, de cada progênie com auxílio de almofariz e pistilo. Aproximadamente $2,5 \mathrm{mg}$ desta farinha foi colocada em um tubo de ensaio e devidamente identificado, uma amostra por progênie. 


\subsubsection{Preparo do Substrato - Linoleato de Sódio (AXELROD, 1981)}

Foram pesados $70 \mathrm{mg}$ de ácido linoléico e $70 \mathrm{mg}$ de Tween 20 que foram homogeneizados com $4 \mathrm{~mL}$ de água destilada livre de oxigênio degaseificada (banho de ultra-som sob vácuo por 20 min.) com auxílio de espátula de plástico. Aos poucos foram adicionados $\mathrm{NaOH} 0,1 \mathrm{~N}$ até a solução ficar incolor. Essa solução foi transferida para um balão volumétrico de $25 \mathrm{~mL}$ e o volume foi completado com água destilada livre de oxigênio (degaseificada). A solução final foi dividida em alíquotas de $3 \mathrm{~mL}$ e mantidas sob refrigeração a $4{ }^{\circ} \mathrm{C}$ e recoberto por papel alumínio até o momento de uso.

\subsubsection{Preparo da Solução de Beta-caroteno (SUDA et al., 1995)}

O $\beta$-caroteno foi dissolvido em $5 \mathrm{~mL}$ de acetona até saturação e centrifugado a $2.000 \mathrm{rpm}$ por quatro minutos. Posteriormente, o sobrenadante foi diluído em igual volume de acetona e acondicionado em um frasco âmbar recoberto com papel alumínio e armazenado a $4{ }^{\circ} \mathrm{C}$ até o momento de sua utilização. Esta solução foi preparada diariamente.

\subsubsection{Preparo do Extrato da Cultivar "Kanto 102"}

As sementes do genótipo "Kanto 102" (presença da lipoxigenase Lox2) foram trituradas até o ponto de farinha. Em um Becker, foram adicionados $1 \mathrm{~mL}$ de água destilada para cada $\mathrm{mg}$ de farinha. Essa solução foi homogeneizada e deixada em repouso por 5 minutos. 


\subsubsection{Preparo da Solução de Azul de Metileno 0,1 mM}

Solubilizaram-se $8,26 \mathrm{mg}$ de azul de metileno em $100 \mathrm{~mL}$ água destilada deionizada e armazenou-se em um frasco âmbar recoberto com papel alumínio.

\subsubsection{As Soluções de Tampão Fosfato 0,2 M e Tampão Borato 0,2M}

O Fosfato de Sódio, buffer (tamponado) pH 6,8 a 0,2M e o Borato de Sódio, buffer (tamponado) $\mathrm{pH}$ 9,5 a 0,2M foram adquiridos previamente preparados pelo fabricante (Dinâmica).

\subsubsection{Preparo das Soluções de Lox1 e Lox3}

Lox3: Foram adicionados $12,5 \mathrm{~mL}$ de tampão fosfato de sódio $0,2 \mathrm{M}$ em um frasco de âmbar recoberto com papel alumínio; 5,0 mL do substrato linoleato de sódio $10 \mathrm{mM} ; 17,5 \mathrm{~mL}$ de água destilada ultrasonificada a vácuo e 5,0 $\mathrm{mL}$ da solução saturada de $\beta$-caroteno.

Lox1: Em um frasco de âmbar recoberto com papel alumínio foram adicionados $25,0 \mathrm{~mL}$ de tampão borato de sódio $0,2 \mathrm{M} ; 5,0 \mathrm{~mL}$ do substrato linoleato de sódio $10 \mathrm{mM} ; 5,0 \mathrm{~mL}$ de água destilada ultrasonificada e 5,0 de azul de metileno $100 \mathrm{mM}$. 


\subsubsection{Teste Para Lipoxigenases 1 e 3}

Em cada tubo de ensaio, contendo a farinha de soja dos genótipos analisados, com uma micro pipeta foram adicionados às soluções seguindo a ordem: $20 \mu \mathrm{L}$ da solução de "Kanto 102"; $250 \mu \mathrm{L}$ da solução de Lox3 e $250 \mu \mathrm{L}$ da solução de Lox.

\subsubsection{Leituras}

Após adicionar os reagentes nas amostras em tubos de ensaio, aguardaram-se 5 minutos para realizar as leituras do teste (na maioria dos casos a reação ocorreu em menos de um minuto).

A presença ou ausência das enzimas lipoxigenases foi determinada pela coloração, sendo incolor para presença das três lipoxigenases; amarela para ausência da isoenzima Lox 3; azul para ausência das enzimas Lox 1 e Lox 2; e verde para ausência das três isoenzimas (Lox 1, Lox 2 e Lox 3). Para detecção das lipoxigenases não houve necessidade de analisar a isoenzima Lox 2 , uma vez que o locus Lox1 encontra-se ligado ao locus Lox2.

Quando detectou triplo nulo, o teste foi repetido em mais quatro amostras, totalizando cinco repetições, para aumentar a probabilidade de o genótipo ser duplo recessivo em ausência de lipoxigenase.

\subsection{RESULTADOS E DISCUSSÃO}

A análise de variância mostrou diferença significativa entre os tratamentos, para todas as variáveis a $\mathrm{P}<0,01$ (Tabela 3). Estes resultados demonstram a diversidade entre os genótipos. Os 
coeficientes de variação para as características oscilaram entre 4,79 a 24,57\% e estão de acordo com Lopes (2002) e Carvalho et al. (2009).

Tabela 3. Resumo da análise de variância de 10 cultivares de soja e 12 cruzamentos, na geração $\mathrm{F}_{2}$, utilizando dados de ensaio conduzido na Fazenda Água Limpa, Brasília, 2014.

\begin{tabular}{ccccccc}
\hline & & \multicolumn{5}{c}{ Quadrado médio } \\
\cline { 3 - 7 } FV & GL & NDM & AP & AIV & NVP & RG \\
\hline Blocos & 3 & 729,071 & 169,991 & 9,192 & 366,465 & 14,858 \\
Genótipos & 21 & $923,058^{* *}$ & $358,336^{* *}$ & $6,948^{* *}$ & $1398,941^{* *}$ & $54,773^{* *}$ \\
Resíduos & 63 & 37,341 & 23,711 & 2,174 & 214,153 & 10,060 \\
\hline Média & 128 & 69,44 & 9,70 & 59,56 & 13,47 \\
CV(\%) & 4,79 & 7,01 & 15,19 & 24,57 & 23,54 \\
\hline ** significativos a P $<0,01$ pelo teste $\mathrm{F}$ & & &
\end{tabular}

** significativos a $\mathrm{P}<0,01$ pelo teste $\mathrm{F}$.

NDM: número de dias para a maturação; AP: altura das plantas; AIV: altura da inserção da primeira vagem; NVP: número de vagens por plantas e RG: rendimento de grãos por planta.

Os resultados das variáveis agronômicas das progênies e dos seus genótipos encontram-se na Tabela 4. O NDM e NVP foram às variáveis que possibilitaram maior discriminação entre os tratamentos, apresentando o maior número de grupos significativamente diferentes. 
Tabela 4. Médias de caracteres agronômicos de 10 cultivares de soja, usados como genitores e 12 cruzamentos na geração $F_{2}$, (provenientes de genitores com ausência de lipoxigenases com soja de período juvenil longo) utilizando dados de ensaio conduzido na Fazenda Água Limpa, Brasília, 2014.

\begin{tabular}{|c|c|c|c|c|c|c|}
\hline & Genótipo & $\begin{array}{l}\text { AP } \\
(\mathrm{cm})\end{array}$ & NDM & $\begin{array}{l}\text { AIV } \\
(\mathrm{cm})\end{array}$ & NVP & $\begin{array}{c}\mathrm{RG} \\
\left.\text { (g.planta }^{-1}\right)\end{array}$ \\
\hline 1 & Amaralina x UFVTN105 & $87,10 \mathrm{a}$ & $130 \mathrm{c}$ & $8,76 \mathrm{~b}$ & $70,00 \mathrm{~b}$ & $10,62 \mathrm{c}$ \\
\hline 2 & Conquista $\mathrm{x}$ UFVTN105 & $82,59 \mathrm{a}$ & $132 \mathrm{c}$ & $10,72 \mathrm{a}$ & $52,34 \mathrm{c}$ & $11,45 \mathrm{c}$ \\
\hline 3 & BRS 257 x DM 309 & $80,82 \mathrm{a}$ & $117 \mathrm{e}$ & $10,54 \mathrm{a}$ & $63,67 \mathrm{c}$ & $12,15 \mathrm{c}$ \\
\hline 4 & M 8585 & $81,00 \mathrm{a}$ & $146 \mathrm{~b}$ & $9,40 \mathrm{~b}$ & $55,00 \mathrm{c}$ & $19,67 \mathrm{a}$ \\
\hline 5 & UFVTN105 & $77,73 \mathrm{a}$ & $121 \mathrm{~d}$ & $9,76 \mathrm{~b}$ & $52,00 \mathrm{c}$ & $17,36 \mathrm{~b}$ \\
\hline 6 & UFVTN105 x M 9144 & $73,40 \mathrm{~b}$ & $128 \mathrm{~d}$ & $9,95 \mathrm{a}$ & $82,12 \mathrm{a}$ & $15,74 \mathrm{~b}$ \\
\hline 7 & M 8585 x UFVTN105 & $71,61 \mathrm{~b}$ & $121 \mathrm{~d}$ & $11,27 \mathrm{a}$ & $57,74 \mathrm{c}$ & $9,17 \mathrm{c}$ \\
\hline 8 & CD 219 & $71,03 \mathrm{~b}$ & $146 \mathrm{~b}$ & $11,20 \mathrm{a}$ & $47,00 \mathrm{c}$ & $13,18 \mathrm{c}$ \\
\hline 9 & M 8585 x BRS 257 & $70,91 \mathrm{~b}$ & $122 \mathrm{~d}$ & $8,60 \mathrm{~b}$ & $68,10 \mathrm{~b}$ & $9,65 \mathrm{c}$ \\
\hline 10 & UFVTN105 x M 8867 & $70,54 \mathrm{~b}$ & $121 \mathrm{~d}$ & $8,94 \mathrm{~b}$ & 93,18 a & $21,70 \mathrm{a}$ \\
\hline 11 & Amaralina & $70,35 \mathrm{~b}$ & $162 \mathrm{a}$ & $11,62 \mathrm{a}$ & $62,00 \mathrm{c}$ & $12,87 \mathrm{c}$ \\
\hline 12 & M 9144 & $70,00 \mathrm{~b}$ & $132 \mathrm{c}$ & $9,20 \mathrm{~b}$ & $60,00 \mathrm{c}$ & $11,85 \mathrm{c}$ \\
\hline 13 & BRS 257 x A 7002 & $69,51 \mathrm{~b}$ & 109 e & $9,54 \mathrm{~b}$ & $89,27 \mathrm{a}$ & $14,88 \mathrm{~b}$ \\
\hline 14 & Conquista & $68,01 \mathrm{~b}$ & $146 \mathrm{~b}$ & $9,66 \mathrm{~b}$ & $41,00 \mathrm{~d}$ & $12,28 \mathrm{c}$ \\
\hline 15 & BRS 257 x CD 219 & $67,74 \mathrm{~b}$ & $117 \mathrm{e}$ & $11,08 \mathrm{a}$ & $59,14 \mathrm{c}$ & $12,49 \mathrm{c}$ \\
\hline 16 & DM 309 & $68,00 \mathrm{~b}$ & $146 \mathrm{~b}$ & $12,00 \mathrm{a}$ & $32,00 \mathrm{~d}$ & $14,66 \mathrm{~b}$ \\
\hline 17 & BRS $257 \times$ Conquista & $65,91 \mathrm{~b}$ & $115 \mathrm{e}$ & $9,01 \mathrm{~b}$ & $59,69 \mathrm{c}$ & $14,10 \mathrm{c}$ \\
\hline 18 & BRS 257 x M 9144 & $63,35 \mathrm{c}$ & $121 \mathrm{~d}$ & $8,70 \mathrm{~b}$ & $91,52 \mathrm{a}$ & $17,24 \mathrm{~b}$ \\
\hline 19 & A 7002 & $59,00 \mathrm{c}$ & $132 \mathrm{c}$ & $10,35 \mathrm{a}$ & $43,00 \mathrm{~d}$ & $10,75 \mathrm{c}$ \\
\hline 20 & M 8867 & $58,15 \mathrm{c}$ & $132 \mathrm{c}$ & $8,62 \mathrm{~b}$ & $53,00 \mathrm{c}$ & $17,83 \mathrm{a}$ \\
\hline 21 & BRS 257 x M 8867 & $57,68 \mathrm{c}$ & $116 \mathrm{e}$ & $7,84 \mathrm{~b}$ & $62,08 \mathrm{c}$ & $10,91 \mathrm{c}$ \\
\hline 22 & BRS 257 & $45,00 \mathrm{~d}$ & $94 \mathrm{f}$ & $6,60 \mathrm{~b}$ & $16,00 \mathrm{e}$ & $5,86 \mathrm{c}$ \\
\hline
\end{tabular}

Médias seguidas de mesma letra na coluna não diferem pelo teste de Scott $\operatorname{Knott}(\mathrm{P} \leq 0,05)$. AP: altura de plantas; AIV: altura de inserção de vagens; NDM: número de dias para a maturação; AP: altura de planta; AIV: altura da primeira vagem; NVP: número de vagem por planta; RG: rendimento de grãos por planta. 


\subsubsection{Altura de Plantas}

Verificou a formação de quarto grupos significativos para altura de plantas (Tabela 4). A altura geral variou de 44,75 a 87,10 cm entre BRS 257 e Amaralina x UFVTN105. O primeiro grupo apresentou média de $81,8 \mathrm{~cm}$ e foi formado por cinco genótipos destes três cruzamentos (Amaralina x UFVTN105, Conquista x UFVTN105, BRS 257 x DM 309) e dois genitores (UFVTN105 e M 8585).

No segundo grupo ficaram inseridos 55\% dos genótipos que variaram de 65,91 a 73,40 cm, destes cinco genitores (CD 219, Amaralina, M 9144, Conquista, DM 309) com média de 69,30 $\mathrm{cm}$. Observou-se ainda que três dos cruzamentos com UFVTN105 como genitor feminino (UFVTN105 x M 9144, M 8585 x UFVTN105, UFVTN105 x M 8867) e três com BRS257 (BRS 257 x A 7002, BRS 257 x CD 219, BRS 257 x Conquista) ficaram inseridos neste grupo.

O terceiro grupo teve média de $59,5 \mathrm{~cm}$ e foi formado por quarto genótipo, destes dois genitores (A 7002 e M 8867) e dois cruzamentos (BRS 257 x M 9144 e BRS 257 x M 8867). O quarto grupo foi compreendido apenas pela BRS $257 \mathrm{com}$ AP de $44,75 \mathrm{~cm}$.

Existe uma maior aceitação de cultivares cujas alturas de plantas variam entre 60 e 120 para se adequarem à colheita mecanizada (REZENDE; CARVALHO, 2007).

Os resultados de altura de plantas para os genitores diverge dos encontrados por Santos et al. (2011) exceto BRS 257. O que possivelmente, influenciou na altura dessas plantas foi o espaçamento adotado nas entre linhas $(1 \mathrm{~m})$ e pelo fato da planta de soja apresenta alta plasticidade (PIRES et al., 2000). O crescimento da soja é influenciado pelo espaçamento entre linhas; menores espaçamentos resultam em maior crescimento de plantas, enquanto os maiores espaçamentos proporcionam menor altura de plantas e aumento das ramificações. 


\subsubsection{Maturação}

O NDM possibilitou formação do maior número de grupos entre as variáveis, seis. Os valores variaram de 94 a 162 dias entre os grupos formados por BRS 257 e Amaralina, respectivamente, com uma amplitude de 68 dias. Trabalho realizado por Santos et al. (2011) e Capone (2015) ao avaliar esses genótipos em Tocantins verificaram esse mesmo comportamento para BRS 257 (mais precoce) enquanto Amaralina mostrou-se mais tardio.

O segundo grupo foi composto por quatro genitores (M 8585, CD 219, Conquista e DM 309). Todos apresentaram maturação aos 146 dias. A maturação média do terceiro grupo foi 132 dias, esse grupo foi integrado por dois cruzamentos (Amaralina x UFVT N105 e Conquista $x$ UFVTN 105) com média de 131 dias e três genitores (M 9144, A 7002 e M8867) com média de 132 dias. No quarto grupo observou maturação média aos 122 dias, sendo este composto por seis genótipos todos os cruzamentos, exceto UFVTN 105.

O quinto grupo apresentou maturação média aos 115 dias e foi formado por cinco cruzamentos onde todos eles têm em comum o genitor feminino BRS 257 (BRS 257 x DM 309, BRS 257 x A 7002, BRS 257 x A 7002, BRS 257 x Conquista e BRS 257 x M 8867). O sexto grupo foi composto por apenas BRS 257 com maturação aos 94 dias. Diante desses resultados verifica-se uma diferença de 21 dias na maturação entre o genitor feminino BRS 257 e a média de seus cruzamentos que compõem o quinto grupo.

Ao se analisar cruzamentos envolvendo BRS 257 como genitor feminino observou-se que apenas BRS 257 x M 9144 foi inserido no quarto grupo, os demais no quinto grupo, onde se obteve o menor número de dias para maturação. Logo, esses cruzamentos produzem recombinantes mais precoces em relação aos demais, com provável herança para precocidade proveniente do genitor 
feminino BRS 257.

\subsubsection{Altura da Primeira Vagem}

Formaram-se dois grupos significativos para AIV (Tabela 4). O primeiro teve $41 \%$ dos genitores em sua integração, englobando tanto genitores quanto cruzamentos. A AIV para esse grupo variou de 9,95 a 12 cm entre UFVTN105 x M 9144 e DM, respectivamente.

Observou-se que 59\% dos genótipos ficaram no segundo grupo de AIV. Desses, 38\% foram genitores e $62 \%$ cruzamentos. Esse grupo ainda apresentou amplitude 3,6 cm entre UFVTN105 e BRS 257. Para que não haja perda na colheita, a altura mínima da primeira vagem mostrou-se eficiente quando superior a 10 centímetros (ALMEIDA et al., 2011). Apenas quatro dos 12 cruzamentos avaliados apresentaram altura superior à indicada na literatura. Assim, em gerações mais avançadas fazem-se necessários estudos mais detalhados para verificar a influencia ambiental.

\subsubsection{Número de Vagens por Planta}

Número de vagens por planta proporcionou a formação do segundo maior número de grupos (cinco) significativos entre as variáveis (Tabela 4). O primeiro e o quinto grupo foram os mais contrastantes, com valores médios que variaram de 16 a 89 vagens por planta, com diferença de 73 vagens. Isso demostra a variabilidade existente entre os genótipos testados e o efeito da recombinação entre ausência de lipoxigenase e PJL. 
O primeiro grupo foi formado por quatro cruzamentos (UFVTN 105 x M 8867, BRS 257 x M 9144, BRS 257 x A 7002 e UFVTN 105 x M 9144) com média de 89 vagens por planta (Tabela 4). O segundo grupo apresentou média de 69 vagens e foi composto por dois cruzamentos (Amaralina x UFVTN 105 e M 8585 x BRS 257). Percentualmente o segundo grupo foi $22 \%$ inferior ao primeiro. Os resultados obtidos nestes dois grupos estão em conformidade aos resultados obtidos por de Santos et al. (2011) e Souza et al. (2013). E divergem dos obtidos por Martins et al. (2002) que alcançou valores superiores a 100 vagens por planta.

O terceiro grupo teve 55\% das progênies em sua integração (Tabela 4). Para esse grupo, ainda foi observada uma amplitude de 15 vagens entre CD 219 e BRS 257 x M 8867. Seis dos genitores encontram-se inseridos neste terceiro grupo os quais apresentaram em média de 55 vagens. Em média o NVP neste grupo foi $33 \%$ inferior em relação ao primeiro. O quarto grupo foi formado por três genitores (DM 309, Conquista e A 7002) que apresentaram médias de 32, 41 e 43 vagens por planta, respectivamente.

O quinto grupo foi formado pelo BRS 257, com 16 vagens por planta. Os valores obtidos para esse genótipo aproximam aos obtidos por Santos et al. (2013) ao introduzir linhagens de soja hortaliça na Bahia.

\subsubsection{Rendimento de Grãos}

O rendimento médio de grãos foi de $13,47 \mathrm{~g} /$ planta (Tabela 3). Foram formados três grupos significativos para essa variável (Tabela 4). Os primeiro grupo foi integrado por três genótipos, destes dois genitores M 8585 com 19,67 g/planta e M 8867 com 17,83 g/planta, ambos recomendados ao cultivo em baixas latitudes. Ainda integrou este grupo o cruzamento UFVTN 
105 x M 8867 com 21,90 g/planta. Observou-se ainda neste grupo, que a média das progênies superou a dos genitores.

O segundo grupo de RG foi formado por cinco genótipos (dois genitores e três cruzamentos). Observou-se ainda que, em média, os cruzamentos e genitores equivaleram-se com 16 g/planta. Integraram o terceiro grupo de RG 14 dos 22 genótipos. Esse grupo apresentou média de 11,23 g/planta com amplitude de 7,32 g/planta. Verificou-se ainda, que dos 14 genótipos que constituíram o terceiro grupo, oito são cruzamentos e seis genitores. Logo, tanto genitores quanto cruzamentos apresentaram baixo rendimento de grãos (67\% dos cruzamentos e $60 \%$ dos genitores formaram inseridos nesse grupo com menores valores para RG).

Verificou que os genitores e os cruzamentos equivaleram em rendimento de grãos: o primeiro com média de 13,63 g/planta e o segundo com média de 13,34 g/planta, com diferença apenas de 0,30 g/planta. Os valores obtidos nesta pesquisa para RG divergem aos encontrados por Martins et al. (2002) em plantas de soja, geração $F_{2}$.

O genitor BRS 257 apresentou os menores valores para todas variáveis avaliadas, mostrando sua falta de adaptação ao ambiente de cultivo (Tabela 4). Entretanto, não apresenta os genes que codificam as três enzimas de lipoxigenases, sendo assim fonte de diversidade genética, originando novos recombinantes em hibridações. Em estudos no Tocantins, esse genótipo foi introduzido apresentou extrema precocidade e baixo desempenho agronômico, demonstrando baixa adaptabilidade (SANTOS et al., 2011).

Dos doze cruzamentos obtidos, sete apresentaram progênies com altura igual e superior a $70 \mathrm{~cm}$ e com ausência das tres enzimas de lipoxigenases (Tabela 5). As 35 progênies obtidas analisadas foram distribuídas dentro dos cruzamentos, com variações em NDM, AP, AIV, NVP e RG. Os cruzamentos combinando TN com AP igual e superior a $70 \mathrm{~cm}$ foram BRS257 x CD219, 
BRS 257 x M 9144, BRS 257 x DM 309, M 8585 x BRS 257, M 8585 x UFVTN 105, Amaralina x UFVTN 105 e M 9144 x UFVTN 105.

Foram obtidas duas progênies TN no cruzamento BRS257 x CD219 (Tabela 5) com dois ciclos distintos, porém pouca variação em AP com média de $71 \mathrm{~cm}$. A AIV ficou dentro daquelas estabelecidas pela literatura $(10$ e $11 \mathrm{~cm})$. O número de vagens e o rendimento de grão teve uma alta variação entre essas progênies, sendo a P1C45719 que apresentou resultados mais promissores para caracteres produtivos.

BRS257 x M 9144 (Tabela 5) resultou uma progênie TN (P6C45744), com maturação aos 137 dias e altura de $70 \mathrm{~cm}$. A AIV ficou abaixo do recomendado para a soja. Entretanto, os valores para NVP $(82,50)$ e RG $(14,65 \mathrm{~g})$, a priori, são promissores.

No cruzamento BRS257 x DM 309 foram obtidas sete progênies TN (Tabela 5). A maturação ficou compreendida em três períodos (102, 111 e 128 dias). A AP variou de 73 a 110 cm. As progênies P2C157DM, P69C257DM e P44C257DM apresentaram altura entre 73 a 79 $\mathrm{cm}$; duas obtiveram 86 e $88 \mathrm{~cm}$ (P5C357DM e P57C257DM); P48C257DM e P6C357DM apresentaram altura de plantas de 90 e $110 \mathrm{~cm}$. Duas progênies apresentaram AIV inferior a 10 $\mathrm{cm}$. Todas as progênies apresentaram resultados promissores para NVP e RG, exceto P2C157DM que obteve valores inferiores nestas variáveis.

M 8585 x BRS257 originou três progênies TN (Tabela 5); duas com altura média de 75,5 cm (P23C28557 e P3C48557) e uma com 94 cm (P6C48557); a maturação ocorreu em duas épocas, aos 127 e 137 dias. A P3C48557 e P6C48557 apresentaram valores mais promissores para AIV, NVP e RG. 
Tabela 5. Valores individuais de características agronômicas de 35 progênies de soja, geração $\mathrm{F}_{2}$, identificadas com o gene recessivo para ausência de lipoxigenases (TN) com PJL. Brasília, 2014.

\begin{tabular}{|c|c|c|c|c|c|c|}
\hline Cruzamento /Progênie & NDM & AP $(\mathrm{cm})$ & AIV & NVP & RG (g.planta ${ }^{-1}$ ) & Lox \\
\hline \multicolumn{7}{|l|}{ BRS257 x CD219 } \\
\hline $\mathrm{P} 1 \mathrm{C} 45719$ & 132 & 72 & 11 & 128,00 & 24,74 & TN \\
\hline P11C15719 & 102 & 70 & 10 & 43,33 & 7,67 & TN \\
\hline BRS 257 & 94 & 45 & 7 & 16,00 & 5,86 & $\mathrm{TN}$ \\
\hline CD 219 & 146 & 71 & 11 & 47,00 & 13,18 & - \\
\hline \multicolumn{7}{|l|}{ BRS257 x M 9144} \\
\hline P6C45744 & 137 & 70 & 9 & 82,50 & 14,65 & $\mathrm{TN}$ \\
\hline BRS 257 & 94 & 45 & 7 & 16,00 & 5,86 & $\mathrm{TN}$ \\
\hline M 9144 & 132 & 70 & 9 & 60,00 & 11,85 & - \\
\hline \multicolumn{7}{|l|}{ BRS257 x DM 309} \\
\hline P6C357DM & 118 & 110 & 19 & 89,00 & 18,61 & $\mathrm{TN}$ \\
\hline P48C257DM & 111 & 90 & 20 & 122,00 & 20,39 & TN \\
\hline P57C257DM & 111 & 88 & 5 & 97,00 & 15,58 & $\mathrm{TN}$ \\
\hline P5C357DM & 118 & 86 & 15 & 70,00 & 11,08 & $\mathrm{TN}$ \\
\hline P44C257DM & 111 & 79 & 10 & 84,00 & 19,61 & $\mathrm{TN}$ \\
\hline P69C257DM & 111 & 75 & 6 & 46,00 & 17,35 & $\mathrm{TN}$ \\
\hline P2C157DM & 102 & 73 & 10 & 47,00 & 9,14 & $\mathrm{TN}$ \\
\hline BRS 257 & 94 & 45 & 7 & 16,00 & 5,86 & $\mathrm{TN}$ \\
\hline DM 309 & 146 & 68 & 12 & 32,00 & 14,66 & - \\
\hline \multicolumn{7}{|l|}{ M $8585 \times$ BRS257 } \\
\hline P6C48557 & 137 & 94 & 15 & 80,00 & 17,00 & TN \\
\hline P3C48557 & 137 & 76 & 10 & 135,00 & 20,25 & $\mathrm{TN}$ \\
\hline P23C28557 & 127 & 75 & 4 & 30,00 & 6,56 & $\mathrm{TN}$ \\
\hline M 8585 & 146 & 81 & 9 & 55,00 & 19,67 & - \\
\hline BRS 257 & 94 & 45 & 7 & 16,00 & 5,86 & $\mathrm{TN}$ \\
\hline \multicolumn{7}{|l|}{ M $8585 \times$ UFVTN105 } \\
\hline P9C48505 & 140 & 90 & 13 & 124,00 & 17,66 & TN \\
\hline P11C48505 & 140 & 90 & 11 & 74,00 & 12,48 & $\mathrm{TN}$ \\
\hline P7C48505 & 140 & 85 & 8 & 86,00 & 16,44 & $\mathrm{TN}$ \\
\hline P10C48505 & 140 & 76 & 10 & 67,00 & 12,80 & $\mathrm{TN}$ \\
\hline P20C48505 & 140 & 75 & 11 & 37,00 & 7,00 & $\mathrm{TN}$ \\
\hline $\mathrm{P} 16 \mathrm{C} 18505$ & 107 & 73 & 8 & 50,00 & 7,66 & $\mathrm{TN}$ \\
\hline P10C 18505 & 107 & 70 & 11 & 64,00 & 13,54 & $\mathrm{TN}$ \\
\hline M 8585 & 146 & 81 & 9 & 55,00 & 19,67 & - \\
\hline UFVTN105 & 121 & 78 & 10 & 52,00 & 17,36 & $\mathrm{TN}$ \\
\hline \multicolumn{7}{|l|}{ Amaralina x UFVTN105 } \\
\hline P3C1NA05 & 122 & 95 & 12 & 82,00 & 14,42 & $\mathrm{TN}$ \\
\hline P21C1NA05 & 122 & 95 & 10 & 18,00 & 3,63 & $\mathrm{TN}$ \\
\hline P1C2NA05 & 136 & 93 & 11 & 105,00 & 19,67 & $\mathrm{TN}$ \\
\hline P8C1NA05 & 122 & 92 & 5 & 124,00 & 18,17 & $\mathrm{TN}$ \\
\hline P1C1NA05 & 122 & 90 & 11 & 159,00 & 24,36 & $\mathrm{TN}$ \\
\hline P20C1NA05 & 122 & 90 & 5 & 31,00 & 5,14 & $\mathrm{TN}$ \\
\hline P1C4NA05 & 132 & 90 & 12 & 57,00 & 8,08 & $\mathrm{TN}$ \\
\hline P2C1NA05 & 122 & 80 & 9 & 63,00 & 10,17 & $\mathrm{TN}$ \\
\hline P10C4NA05 & 132 & 76 & 6 & 33,00 & 6,61 & $\mathrm{TN}$ \\
\hline P9C4NA05 & 132 & 75 & 5 & 27,00 & 6,54 & $\mathrm{TN}$ \\
\hline Amaralina & 162 & 70 & 12 & 62,00 & 12,87 & - \\
\hline UFVTN105 & 121 & 78 & 10 & 52,00 & 17,36 & $\mathrm{TN}$ \\
\hline \multicolumn{7}{|l|}{ M 9144 x FVTN105 } \\
\hline P2C34405 & 126 & 80 & 12 & 110,00 & 15,87 & TN \\
\hline M 9144 & 132 & 70 & 9 & 60,00 & 11,85 & - \\
\hline UFVTN105 & 121 & 78 & 10 & 52,00 & 17,36 & $\mathrm{TN}$ \\
\hline
\end{tabular}

NDM: número de dias para a maturação; AP: altura de planta; AIV: altura da primeira vagem;

NVP: número de vagem por planta e RG: rendimento de grãos por planta. 
Sete progênies TN foram obtidas do cruzamento M 8585 x UFVTN105 com dois ciclos de maturação aos 107 e 140 dias (Tabela 5). Em quatro progênies a AP variaram de 70 a 76 cm (M 8585 x UFVTN105, P16C18505, P20C48505 e P10C48505), uma progênie com altura de 85 cm (P7C48505) e duas progênies com 90 cm (P9C48505 e P11C48505). Apenas duas progênies apresentaram AIV de oito centímetros. Verificou para NVP uma alta segregação onde os valores variaram de 37 a 124 vagens. $\mathrm{O}$ rendimento de grão também apresentou uma amplitude de 10 g/planta

O cruzamento Amaralina x UFVTN 105 (Tabela 5) obteve o maior número de progênies TN (10 progênies), as quais foram distribuídas em três ciclos de maturação aos 122, 132 e 136 dias. A altura de planta variou de 75 a $95 \mathrm{~cm}$, destas sete com altura igual e superior a $90 \mathrm{~cm}$. Para AIV cinco progênies foram inferiores a $10 \mathrm{~cm}$. Observou-se ainda que as progênies apresentaram alta amplitude para NVP (141 vagens) e RG (20,73 g/planta).

O Cruzamento M 9144 x UFVTN105 (Tabela 5) originou uma progênie TN, com ciclo de 126 dias e altura de planta com $80 \mathrm{~cm}$. A AIV, NVP e RG apresentaram valores promissores para continuar sendo avaliados em futuras gerações.

Analisando as 35 progênies para altura de plantas, o principal critério para realizar a primeira seleção, verificou que 34,5\% das progênies apresentaram altura superior $90 \mathrm{~cm} ; 11,5 \%$ com altura entre 80 a $89 \mathrm{~cm}$ e $54 \%$ com altura entre 70 a 79.

Em estudos com linhagens triplo-nulas verificaram que a ausência das três lipoxigenases não afetou e não trouxeram efeitos deletérios nas características agronômicas, nem na germinação das sementes (PFEIFFER et al., 1992; MARTINS et al., 2002).

As 35 progênies descritas na Tabela 5, identificadas como triplo nulos e com altura superior a 70 cm, serão usadas para abrir famílias/linhas as quais serão avançadas nas gerações 
consecutivas, a fim de aumentar a endogamia. Posteriormente, essas linhagens serão analisadas em Ensaios Preliminares de Linhagens (EPL) e em Ensaios de Valor de Cultivo e Uso (VCU).

Esses testes mostraram-se necessários, pois além de apresentar ausência de lipoxigenase, as linhagens de soja melhoradas tem que ser avaliadas em ensaios para caracterizar seu desempenho agronômico, potencial produtivo de grãos e adaptabilidade. No avanço de gerações, as linhagens que apresentarem melhores valores agronômicos, adaptabilidade e estabilidade, serão registradas como cultivares.

\subsection{CONCLUSÕES}

As progênies com ciclo mais longo são originadas do cruzamento M 8585 x UFVTN105. O cruzamento Amaralina x UFVTN105 apresenta o maior número de progênies TN e com maior altura de planta.

Os cruzamentos BRS 257 x CD 219, BRS 257 x M 9144, BRS 257 x DM 309, M 8585 x BRS 257, M 8585 x UFVTN105, Amaralina x UFVTN105, M 9144 x UFVTN105 possibilitam obter progênies com ausência de lipoxigenases e com período juvenil longo, adaptadas às baixas latitudes.

\subsection{REFERÊNCIAS}

AGROLINK. Nova variedade de soja chega ao mercado mineiro. 2012. Disponível: <http://www.agrolink.com.br/noticias/nova-variedade-de-soja-chega-ao-mercadomineiro _144148.html>. Acesso: 30 de outubro 2015. 
ALMEIDA, R. D.; PELUZIO, J. M.; AFFÉRI, F. S. Divergência genética entre cultivares de soja, sob condições de várzea irrigada, no sul do Estado de Tocantins. Revista Ciência Agronômica, v. 42, n. 1, p. 108-115, 2011.

AZEVEDO, P. H.; AZEVEDO, V. H.; SEDIYAMA, T.; REIS, M. S.; TEIXEIRA, R. C.; CECON, P. R. Divergência genética entre genótipos de soja ausentes de enzimas lipoxigenases. Revista Ceres, v. 51, p. 663-670, 2004.

AXELROD, B.; CHEESBROUGH, T. M.;. LAASKO, A. N. D., Lipoxygenases from soybeans, Methods Enzymol, v. 71, p. 441-451, 1981.

BATAGLiA, O. C.; MASCARENHAS, H. A. A.; TEIXEIRA, J. P. F.; TISSELI FILHO, O. Acúmulo de matéria seca e nutrientes, em soja cultivar Santa-Rosa, Bragantia, v. 35, n. 21, p. 237-247, 1976.

CAPONE, A. Divergência genética e seleção assistida por marcadores em soja TN. Gurupi: Universidade Federal do Tocantins, 2015. 56 p. Tese Doutorado.

CARRÃO-PANIZZI, M. C.; SILVA, J. B. DA. Soja na alimentação humana: qualidade na produção de grãos com valor agregado. In: Congresso da soja no Mercosul, 2011, Rosário. Anais..., Rosário: ACSOJA, 2011. 
CARRÃO-PANIZZI, M. C. Melhoramento genético da soja para a obtenção de cultivares mais adequados ao consumo humano. Revista Brasileira de Nutrição Clinica, v. 15, p. 330-340, 2000.

CARVAlHO, A. D. F.; GERALDI, I. O.; SANTOS, V. S. Evaluation of $F_{2:} 4$ and F $4: 6$ progenies of soybeans and perspectives of using early generation testing for grain yield. Bragantia, v. 68, n. 4, p. 857-861, 2009.

DANTAS, M. I. S.; SILVA, M. G.; PINTO, C. R. R.; PEREIRA, C. A. S. P.; MINIM, V. P. R.; BITTENCOURT, M. C. B. Farinhas de soja sem lipoxigenase agregam valor sensorial em bolos. Revista Ceres, v. 57, n.2, p. 141-144, 2010.

EMBRAPA. Evolução e perspectivas de desempenho econômico associadas com a produção de soja nos contextos mundial e brasileiro. Documentos 319. 2011. Disponível <http://www.cnpso.embrapa.br/download/Doc319_3ED.pdf>. Acesso: 18 de março 2013.

FARINHA, J. V.; MARTINS, D.; COSTA, N. V.; DOMINGOS, V. D. Deposição da calda de pulverização em cultivares de soja no estádio R 1 . Ciência Rural, v. 39, n. 6, p. 1738-1744, 2009.

FEHR, W. R.; CAVINESS, C. E. Stages of soybean development. Iowa State University. 1977. 12 p (Special Report, 80). 
KIKUCHI, A; CARRÃO-PANIZZI, M. C. Simple and rapid method for the detection of lipoxigenase isozymes in soybean seeds. JIRCAS Anual Report 2001, n. 8, p. 47-48, 2001.

KINOUCHI, F. L.; CARDELlO, H. M. A. B.; ROSSI, E. A.; TELAROLLI JÚNIOR, R. Aceitação do "Iogurte" de Soja Entre Adolescentes. Revista Alimento e Nutrição, n. 13, p. 131$142,2002$.

KITAMURA, K.; DAVIES, C.S.; KAIZUMA, N. Genetic analysis of a null-allele for lipoxygenase-3 in soybean seeds. Crop Science, v. 23, n.5, p. 924-927, 1983.

LOPES, A. C. A.; VELlO, N. A.; PANDINI, F.; ROCHA, M. M.; TSUTSUMI, C. Y. Variabilidade e correlações entre caracteres em cruzamentos de soja. Scientia Agricola, v. 59, n. 2, p. 341-348, 2002.

MARTINS, C. A. O.; SEDIYAMA, C. S; MOREIRA, M. A.; REIS, M. S.; ROCHA, V. S.; OLIVEIRA, M. G. A. Efeito da eliminação genética das lipoxigenases sobre as características agronômicas da soja. Pesquisa Agropecuária Brasileira, v. 37, n.10, p. 1389-1398, 2002.

MONTEIRO, M. R. P.; COSTA. N. M. B.; OLIVEIRA, M. G. A.; PIRES, C. V.; MOREIRA, M. A. Protein quality of soy lines lacking Kunitz's Trypsin Inhibitor and Lipoxygenase isozymes. Review of Nutrition, v. 17, n. 2, p. 195-205, 2004. 
MOTTA, I. S.; BRACCINI, A. L.; SCAPIM, C. A.; GONÇALVES, A. C .A.; BRACCINI, M. C. L. Características agronômicas e componentes da produção de sementes de soja em diferentes épocas de semeadura. Revista Brasileira de Sementes, v. 22, n. 2, p. 257-267, 2000.

PFEIFFER, T. W.; HILDEBRAND, D. F.; TEKRONY, D. M. Agronomic performance of soybean lipoxygenase isolines. Crop Science, v. 32, p. 357-362, 1992.

PIRES, J. L. F. COSTA, J. A. THOMAS, A. L. MAEHLER, A. R. Efeito de populações e espaçamentos sobre o potencial de rendimento da soja durante a ontogenia. Pesquisa Agropecuária Brasileira, v. 35, n. 8, 2000.

REZENDE, P. M.; CARVALHO, E. A. Avaliação de cultivares de soja Glycine max (L.) Merrill para o sul de Minas Gerais. Ciência e Agrotecnologia, v. 31, n. 6, p. 1616-1623, 2007.

ROCHA, R. S.; SILVA, J. A. L.; NEVES, J. A.; SEDIYAMA, T.; TEIXEIRA, R. C. Desempenho Agronômico de variedades e linhagens de soja em condições de baixa latitude em Terezina-PI. Revista de Ciências Agrárias, v. 43, n. 1, p.154- 162, 2012.

SANTOS, J. M. S.; PEIXOTO, C. P.; RANGEL, M. A. S.; CRUZ, T. V.; SILVA, R. N. A.; LEDO, C. A. S. Desempenho agronômico de genótipos de soja hortaliça cultivados no recôncavo Baiano. Rev. Bras. Ciênc. Agrár., v. 8, n. 3, p. 402-407, 2013. 
SANTOS, E. R.; BARROS, H. B.; FERRAZ, E. C.; CELLA, A. J. S.; CAPONE, A.; SANTOS, A. F.; FIDELIS, R. R. Divergência entre genótipos de soja, cultivados em várzea irrigada. Rev. Ceres, v. 58, n. 6, p. 755-764, 2011.

SILVA, J. B.; CARRÃO-PANIZZI, M. C.; PRUDÊNCIO, S. H. Chemical and physical composition of grain type and food type soybean for food processing. Pesquisa Agropecuária Brasileira, v. 44, n. 7, p. 777-784, 2009.

SOUZA, C. A. et al. Arquitetura de plantas e produtividade de soja decorrente do uso de redutores de crescimento. Bioscience Journal, v. 19, n. 3, p. 634-643, 2013.

SPEHAR, C. R., FRANCISCO, E. R.; PEREIRA, E. A. Yield stability of soybean cultivars in crop seasons and sowing dates at low latitude Brazilian Savannah Highlands. Journal of Agricultural Science, v. 153, p. 1059-1068, 2014.

SPEHAR, C. R. Comparison between hill and row plots methods on selection of soybeans for aluminium tolerance in a Brazilian savannah (Cerrado) acid soil. Pesquisa Agropecuária Brasileira, v. 33, n. 6, p. 899-904, 1998.

SUDA, I.; HAJIKA, M.; NISHIBA, Y.; FURUTA, E.; IGITA, K. Simple and rapid method for the selective detection of individual lipoxygenase isozymes in soybean seeds. Journal of Agricultural and Food Chemistry, v. 43, p. 742-747, 1995. 
CAPÍTULO 4. ESTIMATIVA DE PARÂMETROS DE VARIAÇÃO GENÉTICA EM PROGÊNIES F 2 DE SOJA E GENITORES COM PRESENÇA E AUSÊNCIA DE LIPOXIGENASES

CHAPTER 4. PARAMETERS ESTIMATE OF GENETIC VARIATION IN PROGENIES F 2 SOYBEAN AND PARENTS WITH PRESENCE AND FREELIPOXYGENASE 


\section{RESUMO}

Objetivou-se com este trabalho estimar parâmetros genéticos (herdabilidade, coeficiente de variação genética e razão da variação genética e ambiental $\mathrm{CVg} / \mathrm{CVe}$ ), calcular as correlações fenotípicas e dispersão gráfica entre caracteres agronômicos em populações de soja formadas por cruzamento biparentais e seus genitores. A seleção foi concentrada em altura de plantas (AP) e de inserção de vagem (AIV), número de dias para maturação (NDM), número de vagens por planta (NVP) e rendimento de grãos (RG). O experimento foi conduzido no Distrito Federal, latitude $15^{\circ} 56^{\prime} \mathrm{S}$, longitude $47^{\circ} 56^{\prime} \mathrm{W}$ e altitude de $1.080 \mathrm{~m}$, em latossolo vermelho amarelo. A semeadura foi realizada em dezembro de 2013. O delineamento experimental foi o de blocos casualizados com quatro repetições. Os tratamentos foram constituídos por 22 genótipos (10 genitores e 12 cruzamentos). A parcela experimental foi constituída por uma linha com 2,5 m de comprimento, espaçada por $100 \mathrm{~cm}$. A análise mostrou ganhos para os caracteres estudados, medidos pela herdabilidade $\left(\mathrm{h}_{\mathrm{a}}{ }^{2}\right)$. A razão $\mathrm{CVg} / \mathrm{CV}$ e mostrou seleção favorável para NDM, AP, NVP e RG. A maior variabilidade genética $(\mathrm{CVg})$ encontrada foi para NVP e RG. As correlações apresentaram magnitude média entre os caracteres NDM e AP, NDM e AIV, AP e AIV, AP e NVP, e NVP e RG. A seleção por NVP resulta em maior rendimento por planta. A dispersão gráfica permitiu observar os genótipos de forma isolada, indicando os cruzamentos mais promissores para serem avançados no procedimento de seleção.

Palavras-chave: Glycine max, cruzamento biparental, herdabilidade, correlação, CVg/CVe, dispersão gráfica. 


\begin{abstract}
Estimate of genetic parameters at early generations can increase the selection efficiency process in breeding programs. In view of this, the work aimed at estimating genetic parameters (heritability, genetic coefficient of variation and the ratio between genetic and environmental variation - $\mathrm{CVg} / \mathrm{CVe})$, calculate phenotypic correlations and graphic dispersion among agronomic characters in soybean $\mathrm{F}_{2}$ progenies from bi-parental crosses and genitors. The selection was concentrated in plant height $(\mathrm{PH})$ and first pod (FPH), number of days to maturity (NDM), number of pods per plant (NPP) and grain yield (GY). The experiment was conducted in the Federal District, $15^{\circ} 56^{\prime} \mathrm{S}$ and $47^{\circ} 56^{\prime} \mathrm{W}, 1,080 \mathrm{~m}$ altitude, in savannah red yellow latosol.

Sowing was carried out in December 2013, using a complete randomized bloc design with four repetitions. The treatments were made by 22 genotypes (10 genitors and 12 crosses). The experimental unit consisted of a $2.5 \mathrm{~m}$ single row plot, spaced by $0.5 \mathrm{~m}$. Each bloc was spaced from the others by $1.0 \mathrm{~m}$. The analyses showed gains for the characters, measured by heritability $\left(\mathrm{h}_{\mathrm{a}}{ }^{2}\right)$. The $\mathrm{CVg} / \mathrm{CV}$ e ratio showed selection effectiveness for NDM, PH, NPP e GY. The largest genetic variability $(\mathrm{CVg})$ was detected by NPP and GY. The correlations were of médium magnitude for NDM and PH, NDM and FPH, PH and FPH, PH and NPP, and NPP and GY. The paired correlation indicates selection for NDM leads to gain for FPH. Selection for NPP results in high GY. The graphic dispersion allows to observe genotypes one by one and indicates the the promising crosses to be advanced in the selection procedure.
\end{abstract}

Key-words: Glycine max, biparental cross, heritability, correlation, $\mathrm{CVg} / \mathrm{CVe}$, graphic dispersion. 


\subsection{INTRODUÇÃO}

Os programas de melhoramento genético de soja têm desenvolvido cultivares baseando nas demandas de mercado. Instituições, públicas ou privadas, possuem programas de melhoramento como estratégias e objetivos diferentes. O foco tem se concentrado na obtenção de cultivares mais produtivas, que expressem resistência a nematoides, doenças fungicas e insetos, estresse hídrico, salinidade, alumínio (SPEHAR et al., 2014). Inclui-se ainda seleção por demanda especifica, como alto teor de óleo, proteínas ou com ausência de lipoxigenases resultando em melhor sabor (ANDRADE, 2012).

Existem poucas informações sobre seleção em soja nas gerações iniciais após hibridação. Isso ocorre pela dificuldade de realização dos cruzamentos, limitada quantidade de sementes colhidas nas plantas $F_{1}$, além do trabalho despendido com as avaliações. Testes em gerações iniciais $\left(\mathrm{F}_{1}, \mathrm{~F}_{2}, \mathrm{~F}_{3}\right)$ possibilitam quantificar os efeitos sobre a expressão fenotípica dos caracteres e as estimativas de parâmetros genéticos importantes na seleção de genótipos, tais como, variância genética, herdabilidade e correlação entre caracteres (LOPES et al., 2002).

Logo, o conhecimento da variabilidade genética nos programas de melhoramento, permite a seleção de genitores que originam população com maior proporção de recombinantes desejáveis. Para os melhoristas, interessa a obtenção de variabilidade que efetivamente resulte em ganhos genéticos significativos (MUNIZ, 2007; VASCONCELOS et al., 2015).

A herdabilidade $\left(h^{2}\right)$ é uma estimativa expressando a proporção da variância genética sobre a variância fenotípica. A herdabilidade é uma propriedade não somente do caráter de interesse, dependendo da magnitude de todos os componentes de variância, pois, alteração em qualquer um deles afetará o seu valor (BORÉM; MIRANDA, 2009). A estimativa de $\mathrm{h}^{2}$ desse aplica a uma 
dada população, sendo específica ao ambiente no qual os genótipos foram estudados. Adicionalmente, podem-se estimar herdabilidade diferentes para serem usadas em cálculos de predição, variando a unidade de seleção (OLIVEIRA et al., 2000). Valores altos de ${ }^{2}{ }^{2}$ indicam que métodos de seleção simples como seleção massal podem levar a ganhos consideráveis, considerando que o ambiente apresenta pouca influência (FALCONER, 1981).

A razão $\mathrm{CVg} / \mathrm{CVe}$ pode ser empregada como índice indicativo do grau de eficiência seletiva das progênies para cada caráter. Quando a razão $\mathrm{CVg} / \mathrm{CVe}$ for igual ou maior que a unidade, tem-se uma situação favorável à seleção, ou seja, a variação genética é a maior responsável pelas diferenças entre progênies (YOKOMIZO; FARIAS NETO, 2003).

A correlação pode ocorrer quando um gene interfere na expressão de outros. Se estiver segregando, causará variação simultânea nesses dois caracteres. Correlações positivas mostram, possivelmente, desequilíbrio de ligação gênica entre os pares, favorecendo a seleção simultânea de dois ou mais caracteres, com base em um destes. Em contrapartida, a seleção de um caráter pode acarretar seleção de alelo indesejável em outro gene. A correlação tem sido usada como estratégias para aumentar a eficiência do melhoramento genético, indicando a influencia que um caráter exerce sobre outro. Esse parâmetro explica o grau de associação entre duas variáveis, e, quando elas estão correlacionadas positivamente, existe uma covariação entre elas (RAMALHO, 2004).

Trabalhos para estimar a variabilidade genética e ambiental em soja têm sido explorados, com base em caracteres agronômicos em diferentes ambientes. Herdabilidade e correlações em plantas $\mathrm{F}_{2}$ de soja, triplo nula foram avaliadas em Minas Gerais (OLIVEIRA et al., 2000; LOPES et al., 2002). Correlações entre genótipos de soja cultivada sob condições de várzea irrigada, foram obtidas no cultivo em Tocantins (ALMEIDA et al., 2010). Matsuo et al. (2012) estimaram 
parâmetros genéticos na variação do hipocótilo e epicótilo; estimativas de parâmetros genéticos e suas correlações entre caracteres agronômicos foram obtidas a partir de genótipos de soja avaliados no Piauí (LEITE et al., 2015). Enquanto em São Paulo, Unêda-Trevisol et al. (2015) estimaram parâmetros genéticos em linhagens precoces de soja com aptidão para áreas de reforma de canavial.

A estimativa de parâmetros genéticos permite conhecer a estrutura genética de populações para fins de seleção. Este trabalho objetivou estimar parâmetros genéticos (herdabilidade, coeficiente de variação genética e razão da variação genética e ambiental $\mathrm{CVg} / \mathrm{CVe}$ ), calcular correlações fenotípicas entre caracteres agronômicos e variabilidade genética de populações $F_{2}$ de soja formadas por cruzamento biparentais e seus genitores visando aprimorar a seleção para altura de plantas, ciclo e produtividade.

\subsection{MATERIAL E MÉTODOS}

As etapas referentes às hibridações e avanço da geração $F_{1}$ estão descritas no Capítulo 2.

O experimento foi conduzido na Fazenda Água Limpa, Universidade de Brasília (UnB) -

DF, latitude $15^{\circ} 56^{\prime} \mathrm{S}$, longitude $47^{\circ} 56^{\prime} \mathrm{W}$ e altitude média de $1.080 \mathrm{~m}$. Segundo Koeppen, o clima é do tipo Aw tropical chuvoso de inverno seco. O solo é classificado como Latossolo Vermelho-Amarelo - LVA, textura argilosa, fase Cerrado. O solo da área foi analisado quimicamente para recomendação de calagem e adubação, para atender as exigências da cultura.

A semeadura foi realizada em 30 de dezembro de 2013. O delineamento experimental foi o de blocos casualizados com quatro repetições. Os tratamentos foram constituídos por 22 genótipos (Tabela 1). Cada parcela foi composta por uma linha com 2,5 m de comprimento com 
espaçamento de 1,0 m e 0,1 m entre plantas. Cada bloco foi espaçado dos demais por 1,0 m (modificado de SPEHAR, 1998).

Tabela 1: Genótipos de soja avaliados.

\begin{tabular}{llll}
\hline 1- BRS257 & 12- BRS 257 & x & CD 219 \\
2- CD 219 & 13- BRS 257 & x & M 8867 \\
3- DM 309 & 14- BRS 257 & x & M 9144 \\
4- M 8867 & $15-$ BRS 257 & x & A 7002 \\
5- M 9144 & 16- BRS 257 & x & Conquista \\
6- M 7002 & 17- UFVTN105 & x & M 9144 \\
7- Conquista & 18- UFVTN105 & x & M 8867 \\
8- M 8585 & 19- UFVTN105 & x & M 8585 \\
9- UFVTN 105 & 20- M 8585 & x & BRS 257 \\
10- BRS Amaralina & 21- Amaralina & x & UFVTN105 \\
11- BRS 257 x DM 309 & 22- Conquista & x & UFVTN105 \\
\hline
\end{tabular}

- Cultivares destinados a alimentação humana, que apresentam características alimentares e ausência dos alelos dominantes que codificam as três enzimas de lipoxigenases.

Realizaram-se aração e gradagens antecedendo à semeadura, precedida por inoculação e tratamento das sementes com estirpes de Bradyrhizobium japonicum na dose de $500 \mathrm{~g}$ de inoculante para $50 \mathrm{~kg}$ e fungicida Carbendazim-Thiram 200 SC, na dose de $200 \mathrm{~mL} / 100 \mathrm{Kg}$. A adubação foi realizada com base na análise de solo e nas recomendações para a cultura, correspondendo a $500 \mathrm{~kg} \mathrm{ha}^{-1}$ da formulação NPK 00-16-16. O controle das plantas daninhas foi feito por meio de capina manual. Para controle da ferrugem asiática (Phakopsora pachrhizi) foram realizadas pulverizações 0,6 L.ha ${ }^{-1}$ do fungicida Opera ${ }^{\circledR}$ (Piraclostrobina e Epoxiconazol) com intervalos de 20 dias a partir do estádio R 1 (FEHR; CAVINESS, 1977) das plantas de soja. 
A colheita ocorreu a partir de abril de 2014, de acordo com a maturação (estádio R9). As plantas foram colhidas em conjunto de acordo com a maturação por parcela, posteriormente avaliadas, debulhadas e armazenadas individualmente.

As características agronômicas avaliadas foram: a) número de dias para maturação (NDM), período que correspondeu ao período desde a emergência das plântulas até a data em que 95\% das vagens das plantas da parcela apresentaram-se maduras; b) altura das plantas (AP), realizada na maturação medindo da base da planta até a inserção do rácemo no ápice da haste principal; c) altura de inserção da primeira vagem (AIV), realizada na maturação medindo a distância, a partir da base da planta até a primeira vagem da haste principal; d) número de vagens por plantas (NVP), média obtida por contagem direta de vagens por planta; e) rendimento de grãos por planta (RG): determinado após a trilha das plantas e limpeza das sementes convertendo-os em $g$ planta ${ }^{-1}$.

Foi realizada análise de variância com base na média das parcelas, visando avaliar a variabilidade genética entre genitores e cruzamentos. A estimativa dos componentes da variância foi realizada pelo programa Genes (CRUZ, 1997). Foram estimados: variância genotípica entre médias; variância ambiental; herdabilidade no sentido amplo; coeficiente de variação genética; correlações fenotípicas; razão $\mathrm{CVg} / \mathrm{CVe}$, onde valores maiores que 1,0 (um) possibilitam uma seleção efetiva por métodos mais simples de melhoramento e favorecem a seleção fenotípica de caracteres (PIMENTEL-GOMES, 1985; CRUZ et al., 2004).

Foram obtidos ainda coeficientes de correlação entre os caracteres onde: $r=0$ (nula); $0<|r|$ $\leq 0,30$ (fraca); $0,30<|\mathrm{r}| \leq 0,60$ (média); $0,60<|\mathrm{r}| \leq 0,90$ (forte); $0,90<|\mathrm{r}| \leq 1$ (fortíssima) e $|\mathrm{r}|=1$ (perfeita) (CARVALHO et al., 2004). Utilizaram-se gráficos cartesianos para demonstrar a diversidade genética, aplicando-se a análise de coordenadas principais (CRUZ et al., 2004). 


\subsection{RESULTADOS E DISCUSSÃO}

Verificou significância a $\mathrm{p}<0,01$ para todas as características avaliadas (Tabela 2). Esses resultados demostram a variabilidade entre os genótipos testados. O coeficiente de variação está de acordo com o relatado na literatura (LOPES et al., 2002; CARVALHO et al., 2009). Verificou amplitude, entre as médias máxima e mínima, de 68 dias para maturação, 54,6 cm na altura entre plantas, 9,5 cm na altura de primeira vagem, 130 vagens por planta e 30,17 g de grão por planta. Isso confirma a variabilidade encontrada.

Tabela 2. Resumo da análise de variância de 22 genótipos de soja de ensaio conduzido na Fazenda Água Limpa, UnB, Brasília, 2014.

\begin{tabular}{lcccccc}
\hline & & \multicolumn{5}{c}{ Quadrado médio } \\
\cline { 3 - 6 } FV & GL & NDM & AP & AIV & NVP & RG \\
\hline Bloco & 3 & 729,071 & 169,991 & 9,192 & 366,465 & 14,858 \\
Genótipo & 21 & $923,058^{* *}$ & $358,336^{* *}$ & $6,948^{* *}$ & $1398,941^{* *}$ & $54,773^{* *}$ \\
Resíduo & 63 & 37,341 & 23,711 & 2,174 & 214,153 & 10,060 \\
\hline CV(\%) & & 4,79 & 7,01 & 15,19 & 24,57 & 23,54 \\
\hline Média & 127,5 & 69,44 & 9,70 & 59,56 & 13,47 \\
Média max. & 162 & 97,20 & 14,50 & 142,33 & 33,86 \\
Média min. & & 94 & 42,60 & 5,00 & 12,00 & 3,69 \\
\hline
\end{tabular}

** significativos a $\mathrm{P}<0,01$ pelo teste $\mathrm{F}$.

NDM: número de dias para a maturação; AP: altura das plantas; AIV: altura da inserção da primeira vagem; NVP: número de vagens por plantas e RG: rendimento de grãos por planta. 


\subsubsection{Herdabilidade}

O coeficiente de herdabilidade $\left(\mathrm{h}_{\mathrm{a}}{ }^{2}\right)$ reflete os valores de herança e do ambiente na expressão de caracteres. Assim quanto maior esse coeficiente, maior o sucesso da seleção para um dado caráter. Esse coeficiente pode variar de 0 a 1, sendo valores maiores que 0,5 (alta herdabilidade); valores entre 0,2 e 0,5 (herdabilidade média) e menores que 0,2 (herdabilidade baixa) (SILVEIRA et al., 2006). Os valores de coeficientes de herdabilidade $\left(\mathrm{h}_{\mathrm{a}}{ }^{2}\right)$ encontram-se nas (Tabela 3). O número de dias à maturação apresentou maior herdabilidade $\left(\mathrm{h}_{\mathrm{a}}{ }^{2}=0,95\right)$, seguido da altura de plantas $\left(\mathrm{h}_{\mathrm{a}}{ }^{2}=0,93\right)$, número de vagens por planta $\left(\mathrm{h}_{\mathrm{a}}{ }^{2}=0,84\right)$, rendimento de grãos $\left(\mathrm{h}_{\mathrm{a}}{ }^{2}=0,80\right)$ e altura de inserção de vagens $\left(\mathrm{h}_{\mathrm{a}}{ }^{2}=0,68\right)$. Os coeficientes superiores a 0,5 confirmaram alta herdabilidade para essas características com isso indicando serem facilmente fixáveis no avanço de geração (YOKOMIZO, 2012). Resultados semelhantes foram obtidos por na cultura da soja Leite et al. (2015).

Tabela 3. Estimativas das variâncias fenotípica $\left(V_{f}\right)$, genotípica $\left(V_{g}\right)$, ambiental $\left(V_{e}\right)$, herdabilidade sentido amplo $\left(\mathrm{h}_{\mathrm{a}}{ }^{2}\right)$, coeficiente de variação genético $\left(\mathrm{CV}_{\mathrm{g}}\right)$ e razão entre coeficiente de variação genética e ambiental $\left(\mathrm{CV}_{\mathrm{g}} / \mathrm{CV}_{\mathrm{e}}\right)$, para características agronômicas. Fazenda Água Limpa, UnB, DF, Brasília, 2014.

\begin{tabular}{lccccc}
\hline Variância Estimada & NDM & AP & AIV & NVP & RG \\
\hline $\mathrm{V}_{\mathrm{f}}$ (média) & 230,76 & 89,58 & 1,73 & 349,73 & 13,69 \\
$\mathrm{~V}_{\mathrm{e}}$ (média) & 9,33 & 5,92 & 0,54 & 53,53 & 2,51 \\
$\mathrm{~V}_{\mathrm{g}}$ (média) & 221,42 & 83,65 & 1,19 & 296,19 & 11,17 \\
$\mathrm{~h}_{\mathrm{a}}{ }^{2}$ (média) & 0,95 & 0,93 & 0,68 & 0,84 & 0,80 \\
$\mathrm{CV}_{\mathrm{g}}$ & 11,66 & 13,17 & 11,25 & 28,89 & 24,80 \\
$\mathrm{CV}_{\mathrm{g}} / \mathrm{CV}_{\mathrm{e}}$ & 2,43 & 1,87 & 0,74 & 1,17 & 1,05 \\
\hline
\end{tabular}

NDM: número de dias para a maturação; AP: altura de planta; AIV: altura da primeira vagem; NVP: número de vagem por planta e RG: rendimento de grãos por planta. 
Valores de herdabilidade médios a altos indicam que grande parte da variabilidade fenotípica possui causas genéticas, com menor efeito ambiental (UNÊDA-TREVISOLI, et al., 2012).

\subsubsection{Coeficiente de Variação Genético (CVg)}

O coeficiente de variação genético $(\mathrm{CVg})$ é um parâmetro importante que permite inferir sobre a magnitude da variabilidade genética presente na população para todos os caracteres em estudo (FERRÃO et al., 2008), tendo implicações diretas no ganho por seleção. No caso de seleção CVg dá ideia sobre a proporcionalidade do ganho em relação à média, enquanto a razão CVg/CVe maior que a unidade (>1), indica situação favorável à seleção (FALEIRO et al., 2002).

Os coeficientes de variação genética demonstraram a variabilidade genética existente na população para cada caráter (Tabela 3), com variação de 11,25 a 28,89\% entre AIV e NVP, respectivamente. Os caráteres NVP e RG foram os que apresentaram maiores variabilidades ( $\mathrm{CVg}=28,89$ e 24,80\%, respectivamente), enquanto os menores valores foram observados para AIV e AP. Resultados semelhantes de CVg para os caracteres de rendimento e os menores para ciclo, altura de plantas e de primeira vagem foram verificados em outros trabalho (COSTA et al., 2008). De acordo com Ubi et al. (2007), valores elevados são favoráveis à seleção, pois apresentam a possibilidade de maiores ganhos. 


\subsubsection{Razão CVg/CVe}

Essa razão foi maior que a unidade para todas variáveis respostas analisadas (Tabela 3), exceto altura de primeira vagem. Para NDM, AP, NVP e RG, os valores da razão $\mathrm{CVg} / \mathrm{CVe}$ foram 2,$43 ; 1,87 ; 1,17$ e 1,05, respectivamente, estando em concordância com os maiores valores de herdabilidade. Estes valores sugerem boas perspectivas de ganho genético por seleção direta, uma vez que a variância genética superou a ambiental, ou seja, as características manifestaram-se devido a maior contribuição genética (YOKOMIZO, 2012).

A razão $\mathrm{CVg} / \mathrm{CVe}$ foi de 0,74 para altura de primeira vagem. Este valor sugere uma condição pouco favorável à seleção desse caráter, pois a maior contribuição existente foi de origem ambiental. Com o valor maior da variância ambiental do que genético indica que este caráter interage possivelmente de forma intensa com variações ambientais. Neste contexto, sugere-se que no processo de desenvolvimento de linhagens/cultivares de soja, que se utilize outra alternativa como, por exemplo a seleção indireta com auxilio dos coeficientes de correlação deste com outros como maturação e altura de plantas.

A seleção indireta é mais efetiva nessas condições devido à alta magnitude da herdabilidade para altura de plantas, e da correlação feita entre altura de plantas e altura de primeira vagem. A seleção indireta mostra-se eficaz, desde que seja realizada em ambientes responsivos, que maximizem a herdabilidade e correlação (CAIERÃO et al., 2006).

Os resultados obtidos para AIV estão de acordo Leite et al. (2015) que também verificaram coeficiente inferiores a 1 para altura de primeira vagem, enquanto os demais variáveis apresentaram valores superiores a unidade. Entretanto, Silveira et al. (2006) obtiveram valores inferiores a unidade para produtividade. 


\subsubsection{Correlação}

Não foram observadas correlações significativas entre os caráteres avaliados (Tabela 4). Entretanto, os valores foram positivos com magnitude média segundo Carvalho et al. (2004) entre os caráteres NDM e AP, NDM e AIV, AP e AIV, AP e NVP, e NVP e RG. Pode-se inferir que o ciclo da cultura influenciou a altura da planta e a altura da primeira vagem. De modo similar, a altura da planta relacionou-se direta e positivamente com altura de vagem e número de vagens por plantas. E plantas com maior número de vagens também foram as mais produtivas confirmando a tendência encontrada por Almeida et al. (2010).

Tabela 4. Estimativas de valores de correlação fenotípica entre características agronômicas de 22 genótipos de soja. Fazenda Água Limpa. Brasília, 2014.

\begin{tabular}{cccccc}
\hline & NDM & AP & AIV & NVP & RG \\
\hline NDM & 1 & 0,361 & 0,595 & $-0,129$ & 0,244 \\
AP & - & 1 & 0,438 & 0,355 & 0,252 \\
AIV & - & - & 1 & $-0,059$ & 0,078 \\
NVP & - & - & - & 1 & 0,500 \\
REND & - & - & - & - & 1 \\
\hline
\end{tabular}

NDM: número de dias para a maturação; AP: altura de planta; AIV: altura da primeira vagem; NVP: número de vagem por planta e RG: rendimento de grãos por planta.

De acordo com Falconer (1981) essa correlação entre os caracteres permite fazer seleção indireta e obter progresso mais rápido do que na seleção direta. Assim, a seleção realizada apenas número de dias à maturação, que apresentou altas estimativas de herdabilidade $\left(\mathrm{h}_{\mathrm{a}}{ }^{2}=0,95\right)$, favoreceria a seleção indireta na AIV. E selecionando o caractere AP $\left(\mathrm{h}_{\mathrm{a}}{ }^{2}=0,93\right)$ favoreceria a AIV que, a priori, indicou ser de mais difícil seleção, por apresentar valores inferiores de 151 
herdabilidade $\left(\mathrm{h}_{\mathrm{a}}^{2}=0,68\right)$. Ao selecionar o caractere NVP $\left(\mathrm{h}_{\mathrm{a}}^{2}=0,84\right)$ indiretamente seleciona plantas mais produtivas.

\subsubsection{Dispersão Gráfica}

$\mathrm{Na}$ análise visual da figura de componentes principais (Figura 1), pode-se observar que os genótipos apresentaram distribuição heterogênea para as duas primeiras variáveis (Altura de planta e número de dias maturação). Os genótipos mais divergentes foram 1 (BRS 257) e 10 (Amaralina). Os genótipos de maior proximidade foram 17,19 e 20 (UFVTN105 x M 9144, UFVTN105 x M 8585 e M 8585 x BRS 257). Neste grupo englobaram-se apenas progênies referentes aos respectivos cruzamentos; enquanto 4 e 6 (M 8867 e M 7002) e 2, 3 e 7 (CD 219, DM 309 e Conquista), formaram pequenos grupos com dois e três genitores.

As progênies $\mathrm{F}_{2}$ oriundas dos cruzamentos 21 (Amaralina x UFVTN105) e 22 (Conquista X UFVTN 105) apresentaram melhores desempenhos, tanto em relação a AP como no ciclo. Sendo, a priori, os mais promissores para obtenção de genótipos superiores com estas características. Entretanto, as progênies do cruzamento 15 (BRS 257 x A 7002) apresentaram altura superior a 70 cm e foram as mais precoces com maturação aos 107 dias. De forma generalizada, a distribuição das progênies dos cruzamentos (Tabela 2) foi heterogênea e concentraram-se com maturação entre 107 e 128 dias e a altura de plantas entre 58 a $87 \mathrm{~cm}$, respectivamente. 


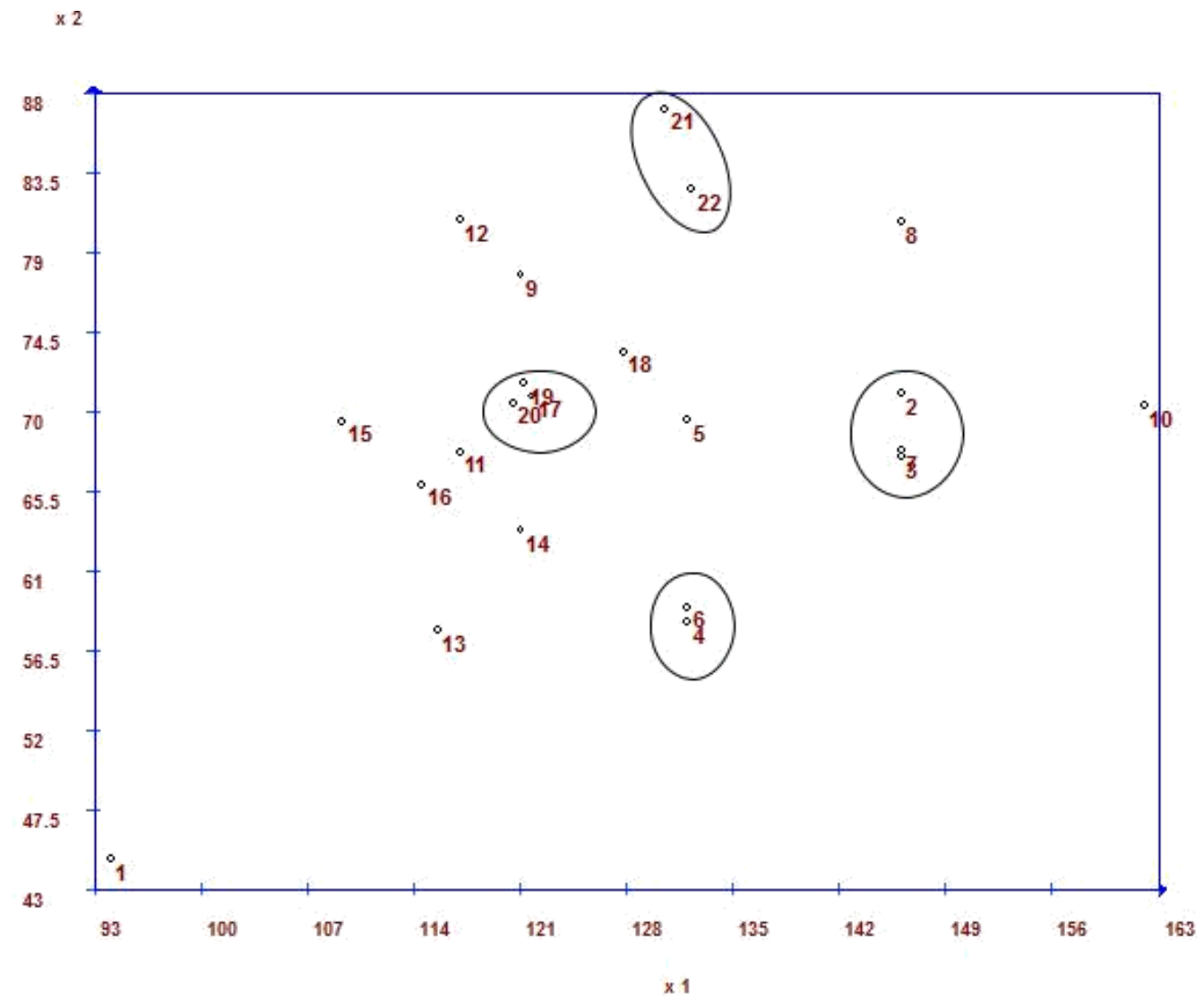

Figura 1. Dispersão gráfica de 22 genótipos de soja 1. BRS257, 2. CD 219, 3. DM 309, 4. M 8867, 5. M 9144, 6. M 7002, 7. Conquista, 8. M 8585, 9. UFVTN 105, 10. BRS Amaralina, 11. BRS 257 x DM 309, 12. BRS 257 x CD 219, 13. BRS 257 x M 8867, 14. BRS 257 x M 9144, 15. BRS 257 x A 7002, 16. BRS 257 x Conquista, 17. UFVTN105 x M 9144, 18. UFVTN105 x M 8867, 19. UFVTN105 x M 8585, 20. M 8585 x BRS 257, 21. Amaralina x UFVTN105 e 22. Conquista x UFVTN105, em relação aos dois primeiros componentes principais, estabelecidos pela combinação linear de cinco características agronômicas. Brasília, DF, 2014.

A dispersão gráfica permitiu visualizar a dissimilaridade genética entre os genótipos. Logo, quanto mais distante sua distribuição gráfica, maior a dissimilaridade entre eles. Essa ferramenta foi usada com sucesso por Santos et al. (2011) e Cabral et al. (2011) em estudos com soja e feijão, respectivamente, para demostrar a dissimilaridade entre os genótipos testados.

A dissimilaridade encontrada refletiu variação genética, elevando a probabilidade de se encontrarem recombinantes desejáveis possuindo período juvenil longo e ausência de 
lipoxigenase. A continuação do trabalho com avanços de geração e seleção até atingir-se homozigose, permitiria obter genótipos de soja tipo alimento adaptada ás baixas latitudes.

\subsection{CONCLUSÕES}

Existe elevada probabilidade de ganhos por seleção evidenciada pelos elevados valores de herdabilidade nas populações de híbridos de soja com período juvenil longo e ausência de lipoxigenase.

A seleção é favorável para número de dias à maturação, altura de plantas, número de vagens por planta e rendimento, com influência ambiental elevada dificultando a seleção por altura de inserção de vagem.

A maior variabilidade genética foi demonstrada por número de vagens por planta e rendimento de grãos.

Correlações positivas com magnitude média entre número de dias à maturação e altura de plantas, número de dias à maturação e altura de inserção de vagem, altura de plantas e altura de inserção de vagem e número de vagens por planta e rendimento permitem seleção indireta para obterem genótipos desejáveis.

A dispersão gráfica permitiu observar os genótipos de forma isolada, apontando os cruzamentos mais promissores para serem avançados. 


\subsection{REFERÊNCIAS}

ALMEIDA, R. D.; PELUZIO, J. M.; AFFERI, F. S. Correlações fenotípicas, genotípicas e ambientais em soja cultivada sob condições de várzea irrigada, sul do Tocantins. Bioscience Journal, v.26, n.1, p.95-99, 2010.

ANDRADE, V. Marcadores morfológicos e moleculares na identificação e distinção de offtype em campos de produção de sementes de soja. Uberlândia: Universidade Federal de Uberlândia, 2012. 63 p. Dissertação Mestrado.

BORÉM, A.; MIRANDA, G. V. Melhoramento de plantas. 5aed. Viçosa: Ed. Viçosa, 2009. 529 p.

CABRAL, P. D. S.; SOARES, T.C. B. S.; LIMA, A. B. P.; ALVES, D. S.; NUNES, J. A. Diversidade genética de acessos de feijão comum por caracteres agronômicos. Revista Ciência Agronômica, n. 42, p. 898-905, 2011.

CAIERÃO, E. V.; CARVALHO, F. I. F.; FLOSS, E. L. Seleção indireta para o incremento do rendimento de grãos em aveia. Ciência Rural, v. 36, p. 1126- 1131, 2006.

CARVALHO, A. D. F.; GERALDI, I. O.; SANTOS, V. S. Evaluation of $\mathrm{F}_{2: 4}$ and $\mathrm{F}_{4: 6}$ progenies of soybeans and perspectives of using early generation testing for grain yield. Bragantia, v. 68, n. 4, p. 857-861, 2009. 
CARVALHO, F. I. F.; LORENCETTI, C.; BENIN, G. Estimativas e implicações da correlação no melhoramento vegetal. Pelotas: Ed. Universitária da UFPel, 2004. 142 p.

COSTA, M. M.; DI MAURO, A. O.; UNÊDA-TREVISOLI, S. H.; ARRIEL, N. H. C.; BÁRBARO, I. M.; SILVEIRA, G. D.; MUNIZ, F. R. S. Heritability estimation in early generations of two-way crosses in soybean. Bragantia, n. 67, p. 101-108, 2008.

CRUZ, C. D. Programa Genes: aplicativo computacional em genética e estatística. Viçosa: Editora UFV, 1997. 442 p.

CRUZ, C. D.; REGAZZI, A. J.; CARNEIRO, P. C. S. Modelos biométricos aplicados ao melhoramento genético. 3. ed. Viçosa: UFV, 480 p, 2004.

FALCONER, D. S. Introdução à genética quantitativa. Viçosa MG: UFV, 1981. 279 p.

FALEIRO, F. G.; CRRUZ, C. D.; CASTRO, C.; MOREIRA, M. A.; BARROS, E. G. Comparação de blocos casualizados e testemunhas intercalares na estimação de parâmetros genéticos em feijoeiro. Pesquisa Agropecuária Brasileira, v. 37, n. 12, p. 1675-1680, 2002.

FEHR, W. R.; CAVINESS, C. E. Stages of soybean development. Iowa State University. 12p (Special Report, 80). 1977. 
FERrÃO, R. G.; CRUZ, C. D.; FERREIRA, A. CECON, P. R.; FERRÃO, M. A. G.; FONSECA, A. F. A. CARNEIRO, P. C. S.; SILVA, M. F. Parâmetros genéticos em café conilon. Pesquisa Agropecuária Brasileira, v. 43, n. 1, p.61-69, 2008.

LEITE, W. S.; PAVAN, B. E.; MATOS FILHO, C. H. A.; FEITOSA, F. S.; OLIVEIRA, C. B. Estimativas de parâmetros genéticos e correlações entre caracteres agronômicos em genótipos de soja. Nativa, v. 3, n. 4, p. 241-245, 2015.

LOPES, A. C. A.; VELLO, N. A.; PANDINI, F.; ROCHA, M. DE M.; TSUTSUMI, C. Y. Variabilidade e correlações entre caracteres em cruzamentos de soja. Scientia Agrícola, v. 59, p. 341-348, 2002.

MATSUO, E.; SEDIYAMA, T.; CRUZ, C. D.; OliVeIRA, R. D. C. T.; CADORE, L. R. Estimates of the genetic parameters, optimum sample size and conversion of quantitative data in multiple categories for soybean genotypes. Acta Scientiarum. Agronomy, v. 34, n. 3, p. 265$273,2012$.

MUNIZ, F. R. S. Análise da variabilidade genética em populações segregantes de soja. Jaboticabal: Universidade Estadual Paulista, 2007. 94 p. Tese Doutorado.

OLIVEIRA, A. C. B.; VIANA, J. M. S.; CRUZ, C. D.; SEDIYAMA, C. S. Herdabilidade e correlações em plantas $F_{2}$ de soja cultivadas em diferentes condições ambientais. Acta Scientiarum, v. 22, p. 889- 893, 2000. 
PIMENTEL-GOMES, F. Curso de estatística experimental. São Paulo: Esalq, 1985. 467 p.

RAMALHO, M. A. P. SANTOS, J. B., PINTO, C. A. B. P. Genética na agropecuária. 3 ed. rev., Lavras: UFLA, 2004. 472 p.

SANTOS, E. R.; BARROS, H. B.; FERRAZ, E. C.; CELLA, A. J. S.; CAPONE, A.; SANTOS, A. F.; FIDELIS, R. R. Divergência entre genótipos de soja, cultivados em várzea irrigada. Rev. Ceres, v. 58, n.6, p. 755-764, 2011.

SILVEIRA, G. D.; MAURO, A. O. D.; CENTURION, M. A. P. C. Seleção de genótipos de soja para a região de Jaboticabal -SP, Ano agrícola 2003-2004. Científica, v. 34, n.1, p. 92-98, 2006.

SPEHAR, C. R., FRANCISCO, E. R.; PEREIRA, E. A. Yield stability of soybean cultivars in crop seasons and sowing dates at low latitude Brazilian Savannah Highlands. Journal of Agricultural Science, v. 153, p. 1059-1068, 2014.

SPEHAR, C. R. Comparison between hill and row plots methods on selection of soybeans for aluminium tolerance in a Brazilian savannah (Cerrado) acid soil. Pesquisa Agropecuária Brasileira, v.33, n.6, p.899-904,1998. 
UBI, B. E.; MIGNOUNA, H.; OBIGBESAN, G. Segregation for seed wight, pod lenghts and days to flowering following a cowpea cross. African Crop Science Journal, v. 9, n. 3, p. 463$470,2007$.

UNÊDA-TREVISOLI, S. H.; SILVA, F. M.; VILLELA, O. T.; ARAÚJO, L. C. A.; DI MAURO, A. O. Estimativa de parâmetros genéticos em linhagens precoces de soja com aptidão para áreas de reforma de canavial. Ciência \& Tecnologia: v. 4, 2012. Suplemento.

VASCONCELOS, E. S; REIS, M. S.; SEDIYAMA, T.; CRUZ, C. D. Produtividade de grãos, adaptabilidade e estabilidade de genótipos de soja de ciclos precoce e médio. Semina, v. 36, n. 3, p. 1203-1214, 2015.

YOKOMIZO, G. K. Produtividade da soja na região do Município de Tartarugalzinho - AP. Comunicado Técnico, Embrapa, p.1-5, 2012.

YOKOMIZO, G. K.; FARIAS NETO, J. T. Caracterização fenotípica e genotípica de progênies de pupunheira para palmito. Pesquisa Agropecuária Brasileira, n. 38, p.67-72, 2003. 


\section{CONCLUSÕES FINAIS}

A análise de crescimento foi eficaz em avaliar a resposta biológica da soja do tipo de alimentos, quando introduzida em baixas latitudes.

A análise dos componentes genéticos demostraram elevada probabilidade de ganhos por seleção evidenciada pelos elevados valores de herdabilidade, $\mathrm{CVg} / \mathrm{CVe}$ nas populações de híbridos. Com seleção favorável para número de dias à maturação, altura de plantas, número de vagens por planta e rendimento. Entretanto, a influência ambiental elevada dificulta a seleção por altura de inserção de vagem.

As correlações demostraram que é possível realizar seleções indiretas daqueles caracteres com menor herdabilidade para obter genótipos desejáveis.

As hibridações entre cultivares de soja com período juvenil longo e cultivares com ausência de lipoxigenase originaram, na geração $\mathrm{F}_{2}, 35$ progênies de soja com período juvenil longo, com altura superior a $70 \mathrm{~cm}$ e ausência de lipoxigenases, com potencial de serem avançadas e lançadas como cultivar no Distrito Federal. 